\title{
ASCERTAINING THE LAWS OF THE SEVERAL STATES: POSITIVISM AND JUDICIAL FEDERALISM AFTER ERIE
}

\author{
BRADFORD R. CLARK $\dagger$ \\ TABLE OF CONTENTS
}

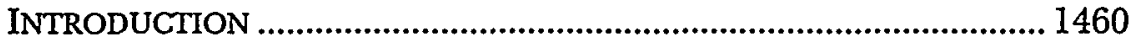

I. ERIE, AMBIGUITY, AND INDEPENDENT JUDGMENT ........................1466

A. Identifying Indeterminacy in State Law.................................... 1467

B. Judicial Federalism and Independent Judgment......................... 1471

1. Erie and the Constitutional Structure ........................... 1474

2. Erie and Independent Judgment ................................... 1493

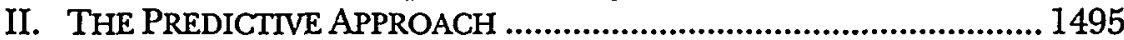

A. Prediction of a Novel Cause of Action.................................... 1502

B. Prediction of a Novel Defense ................................................. 1508

C. Prediction That State Precedent Will Be Overruled ..................... 1514

III. ERIE-BASED ABSTENTION............................................................ 1517

A. The Development of Erie-Based Abstention .............................. 1517

B. Erie-Based Abstention and the Separation of Powers.................. 1524

IV. THE STATIC APPROACH........................................................... 1535

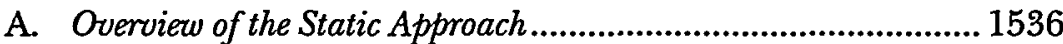

B. The Static Approach and the Constitutional Structure............... 1539

C. The "Political and Social" Defects of the Static Approach........... 1541

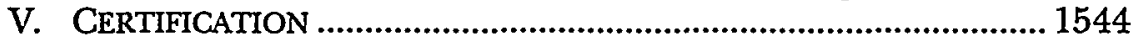

A. The Rise of Certification ..................................................... 1545

B. Certification and the Constitutional Structure ........................... 1549

C. Implementing a Structural Presumption in Favor of

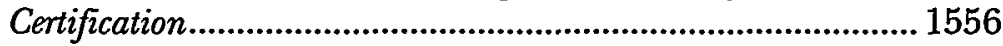

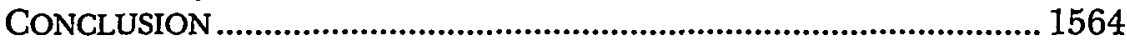

† Associate Professor of Law, George Washington University Law School. I wish to thank Sam Alito, Vik Amar, Jerry Barron, Steven Calabresi, Evan Caminker, Jack Goldsmith, Philip Hamburger, Bruce Hay, Larry Lessig, John Manning, Larry Mitchell, Henry Monaghan, Michael Paulsen, Todd Peterson, Richard Pierce, Roger Trangsrud, Adrian Vermeule, and John Yoo for extremely helpful comments and suggestions. In addition, this paper benefited significantly from comments made at a faculty workshop by my colleagues, Bob Brauneis, Paul Butler, Naomi Cahn, Greg Maggs, Catherine Ross, Mike Selmi, Jonathan Siegel, and Bob Tuttle. I also wish to thank Jason Paradis '98, Adam Schwartz '99, and Michael Hyde '96 for their excellent research assistance. Finally, I thank Dean Jack Friedenthal and the George Washington University Law School for the financial and moral support that made this Article possible. 
"[L]aw in the sense in which courts speak of it today does not exist without some definite authority behind it."

\section{INTRODUCTION}

The Constitution provides that the "judicial Power" of the United States shall extend to controversies "between Citizens of different States," ${ }^{2}$ but does not specify the source of law to be applied in such cases. The first Congress, in section 34 of the Judiciary Act of 1789, directed that "the laws of the several states, except where the constitution, treaties or statutes of the United States shall otherwise require or provide, shall be regarded as rules of decision in trials at common law in the courts of the United States in cases where they apply." ${ }^{3}$ For most of our constitutional history, federal courts interpreted section 34 to permit the application of local or state law in some cases, and so-called "general law" in others. ${ }^{4}$ The Supreme Court endorsed this approach in Swift $v$. Tyson, a case involving a question of general commercial law, and over the course of the next century dramatically expanded the range of matters governed by general common law. ${ }^{6}$ The Court abruptly abandoned this dichotomy in 1938, however, when it overruled Swift sua sponte in Erie Railroad Co. v. Tompkins, and declared-as a matter of constitutional law-that "[e]xcept in matters governed by the Federal Constitution or by Acts of Congress, the law to be applied in any case is the law of the State." ${ }^{88}$ The Court's

${ }^{1}$ Erie R.R. Co. v. Tompkins, 304 U.S. 64, 79 (1938) (quoting Black \& White Taxicab \& Transfer Co. v. Brown \& Yellow Taxicab \& Transfer Co., 276 U.S. 518, 533 (1928) (Holmes, J., dissenting)).

${ }^{2}$ U.S. CONST. art. III, $\$ 2$, cl. 1 .

'Judiciary Act of 1789, ch. $20, \S 34,1$ Stat. 73, 92 (codified as amended at 28 U.S.C. $\$ 1652$ (1994)).

'See generally Bradford R. Clark, Federal Common Law: A Structural Reinterpretation, 144 U. PA. L. REV. 1245, 1279 (1996) (describing "the well-established distinction between lex loci, or local law, and jus gentium, or the law of nations").

51 U.S. (16 Pet.) 1 (1842), overruled by Erie, 304 U.S. at 79.

See infra notes $82-90$ and accompanying text.

7304 U.S. at 79 ("The common law so far as it is enforced in a State, whether called common law or not, is not the common law generally but the law of that State existing by the authority of that State ...." (quoting Black \& White Taxicab \& Transfer Co. v. Brown \& Yellow Taxicab \& Transfer Co., 276 U.S. 518, 533 (1928) (Holmes, J., dissenting))).

${ }^{8} I d$. at 78. Of course, Erie's command refers only to substantive state law; federal courts are generally permitted to apply federal procedural law in federal court. See 
approach in Erie drew support from its conclusion that "no clause in the Constitution purports to confer" "power [upon the federal courts] to declare substantive rules of common law applicable in a State."

When state law is clear, the task of applying "the law of the State" is relatively straightforward. When state law is unsettled or indeterminate, however, Erie's dual command-that federal courts apply but not declare state law-places federal courts in a precarious position. On the one hand, if federal courts exercise independent judgment and fashion common-law rules of decision by weighing competing policy considerations, they arguably usurp the lawmaking power of the states. On the other hand, if federal courts adopt a relatively static view of state law by simply ruling against the proponent of a novel claim or defense, they may unfairly disadvantage federal-court litigants by permitting forum shopping and inequitable administration of the law.

Although the Supreme Court has provided only limited guidance in this area, lower federal courts confronted with this dilemma generally attempt to "predict" what rule the highest court of the state would adopt if the question were before it, and then apply that rule to the case at bar. ${ }^{10}$ This Article suggests that the federal courts' use of the predictive approach itself raises constitutional concerns of the sort underlying the Supreme Court's decision in Erie. Specifically, the predictive approach is in tension with the principles of judicial federalism adopted in Erie to implement the constitutional structure. The Constitution operates to preserve "the autonomy and independence of the States"'11 not only by delegating limited powers to the federal government, but also by carefully restricting the means by which the federal government may exercise such powers. ${ }^{12}$ By and large, the federal government may exercise its powers only through the conduct of actors subject to the "political safeguards of federalism." tion, the Constitution carefully specifies various procedures with

Hanna v. Plumer, 380 U.S. 460, 471 (1965) (“[F]ederal courts are to apply state 'substantive' law and federal "procedural' law ....").

9 Erie, 304 U.S. at 78.

${ }^{10}$ See infra notes 179-93 and accompanying text.

"Erie, 304 U.S. at 78 (quoting Baltimore \& Ohio R.R. Co. v. Baugh, 149 U.S. 368, 401 (1893) (Field, J., dissenting)).

${ }^{12}$ See infra notes 117-36 and accompanying text.

${ }^{15}$ See Herbert Wechsler, The Political Safeguards of Federalism: The Role of the States in the Composition and Selection of the National Government, 54 COLUM. L. REV. 543 (1954) (quoting from the title); infra notes 138-53 and accompanying text. 
which these actors must comply in order to adopt federal law. For example, Congress may exercise its legislative powers to declare substantive rules of law applicable in a state only if it complies with the purposely cumbersome requirements of bicameralism and presentment set forth in Article I, section 7. ${ }^{14}$ Procedures of this kind tend to preserve state power-and thereby safeguard federalism-by sometimes preventing the federal government from exercising the full scope of its delegated powers.

Erie recognized that, in the absence of federal law adopted in accordance with these constitutionally prescribed procedures, "the authority and only authority is the State." 15 Erie employed a positivist conception of state law, under which such law consists exclusively of sovereign commands, and such commands may be issued by whatever organ of the state it deems appropriate. Thus, in Erie, the Court stressed that "whether the law of the State shall be declared by its Legislature in a statute or by its highest court in a decision is not a matter of federal concern." ${ }^{\text {I6 }}$ In either case, absent positive federal law to the contrary, the constitutional structure requires federal courts to respect and apply the law adopted by whatever organs the state has authorized to act on its behalf.

If agents of the state have not adopted rules of decision that provide determinate answers to the questions in the case at bar, then arguably there is simply no law to apply-state or federal-and federal courts should rule against the party who bears the burden of persuasion on the question at issue. This conclusion appears to follow from Erie's embrace of judicial federalism. If a rule of decision applied in federal court does not constitute a command of the state sovereign, then by default the rule in question is, at least in some sense, a command issued by agents of the federal sovereign. The federal courts' enforcement of such commands appears to contradict a fundamental feature of the constitutional structure recognized in Erie-namely, that federal courts (which the Constitution places beyond the reach of the political and procedural safeguards of feder-

${ }^{14}$ U.S. CONST. art. I, $\$ 7$.

${ }^{15}$ Erie, 304 U.S. at 79 (quoting Black \& White Taxicab \& Transfer Co. v. Brown \& Yellow Taxicab \& Transfer Co., 276 U.S. 518, 535 (1928) (Holmes, J., dissenting)).

${ }^{16}$ Id. at 78. The Court was strongly influenced by Justice Holmes's dissent in Black $\mathcal{E}^{2}$ White Taxicab, embracing his understanding that if the "only authority is the State," then "the voice adopted by the State as its own [whether it be of its Legislature or of its Supreme Court] should utter the last word." Id. at 79 (alteration in original) (quoting Black $\mathcal{E}^{2}$ White Taxicab, 276 U.S. at 535 (Holmes, J., dissenting)). 
alism) have "no power to declare substantive rules of common law applicable in a State."

In order to avoid judicial federalism problems of this nature, some federal courts have, on occasion, adopted an alternative approach under which they abstain from adjudicating cases when the application of state law is indeterminate. Under this approach, federal courts generally stay their proceedings and direct the parties to institute a declaratory-judgment action in state court. Although the Supreme Court has permitted-and on occasion even requiredabstention in cases of this kind, ${ }^{18}$ the Court has long maintained that abstention is "the exception, not the rule," presumably because this approach raises distinct constitutional concerns. The general judicial duty to implement constitutional acts of Congress-an aspect of the constitutional separation of powers-arguably gives rise to a "virtually unflagging obligation of the federal courts to exercise the jurisdiction given them." ${ }^{20}$ For this reason, expanded reliance on Erie-based abstention does not appear to be a satisfactory alternative to the predictive approach.

A third approach, adopted by a growing number of federal courts, appears to respond to both federalism and separation-of-powers concerns. Under this approach, federal courts refuse to predict the future development of state law. ${ }^{21}$ Rather, these courts simply "apply the law of the forum as [they] infer it presently to be, not as it might

${ }^{17} \mathrm{Id}$. at 78.

${ }^{18}$ See, e.g., Kaiser Steel Corp. v. W.S. Ranch Co., 391 U.S. 593, 594 (1968) (per curiam) ("The Court of Appeals erred in refusing to stay its hand [as] [t]he state law issue which is crucial in this case ... is a truly novel one [which will] have to be resolved by the New Mexico courts....").

${ }^{19}$ Colorado River Water Conservation Dist. v. United States, 424 U.S. 800, 813 (1976).

${ }^{20}$ Id. at 817; see infra notes 345-58 and accompanying text. Compare Martin $\mathrm{H}$. Redish, Abstention, Separation of Powers, and the Limits of the Judicial Function, 94 YALE L.J. 71,74 (1984) (arguing that "neither total nor partial judge-made abstention is acceptable as a matter of legal process and separation of powers"), with David L. Shapiro, Jurisdiction and Discretion, 60 N.Y.U. L. REV. 543, 545 (1985) (arguing that the abstention doctrines "contribute to the easing of interbranch and intergovernmental tensions," and that judicial discretion, "far from amounting to judicial usurpation ... is wholly consistent with the Anglo-American legal tradition").

${ }^{21}$ See, e.g., Rubinstein v. Collins, 20 F.3d 160, 172 (5th Cir. 1994) ("It is axiomatic, of course, that we will not expand state law beyond its present existing boundaries."); Tritle v. Crown Airways, Inc., 928 F.2d 81, 84 (4th Cir. 1990) (noting that " ${ }^{\text {"t }}$ [f]ederal courts are permitted under Erie... to rule upon state law as it presently exists and not to surmise or suggest its expansion'w (alteration in original) (quoting Washington v. Union Carbide Corp., 870 F.2d 957, 962 (4th Cir. 1989))). 
come to be." ${ }^{22}$ The effect of this static approach is to deny the proponents of unrecognized rules of state law the benefit of such law in the case before the court. This approach alleviates the judicial federalism concerns associated with the predictive approach because federal courts cannot be charged with usurping the lawmaking power of the states. The static approach also mitigates the separation-of-powers concerns raised by abstention because federal courts employing this approach exercise their jurisdiction and adjudicate the case on the merits.

A potential difficulty with the static approach, however, is that it works best in the context of a well-defined and relatively stable body of state law. In reality, neither characteristic is always present. Questions of state law frequently arise in federal court before state courts have had an opportunity to adopt rules of decision specifically designed to govern the transactions in question. Similarly, state courts have been increasingly willing to make rapid and sometimes dramatic changes in state law either by overruling prior precedent or by adopting novel causes of action and defenses. These realities highlight an important constitutional disparity between federal and state courts: State courts are capable of creating and revising "the law of the State" as warranted by circumstances and policy considerations in the case at bar, whereas federal courts may be precluded from exercising similar judicial creativity by principles of judicial federalism. ${ }^{23}$ This disparity, in turn, may give rise to several "political and social" defects ${ }^{24}$ by undermining the so-called "twin aims of the Erie rule"-to discourage forum shopping and to avoid inequitable administration of the law. ${ }^{25}$ In other words, because of "the accident of diversity of citizenship,"26

${ }^{22}$ Dayton v. Peck, Stow \& Wilcox Co., 739 F.2d 690, 694 (1st Cir. 1984) (declining to adopt a new theory of product liability, "[a]bsent some authoritative signal from the [state] legislature or the courts").

${ }^{23}$ See, e.g., Louisiana Power \& Light Co. v. City of Thibodaux, 360 U.S. 25, 29 (1959) (reasoning that a state court is "the only tribunal empowered to speak definitively" on state-law issues).

${ }^{24}$ Erie, 304 U.S. at 74.

${ }^{25}$ Hanna v. Plumer, 380 U.S. 460, 468 (1965) (construing Erie, 304 U.S. at 74-77). The exercise of federal jurisdiction deprives state courts of at least some opportunities to formulate rules of decision specifically designed to govern the conduct of the parties as well as that of other similarly situated individuals. Thus, under the static approach, plaintiffs and defendants will have a strong incentive to invoke federal jurisdiction whenever they would benefit from judicial adherence to the legal status quo. The exercise of federal jurisdiction, in turn, may result in the inequitable administration of the law in cases in which state courts would have fashioned a rule of decision contrary to the one applied in federal court. See infra Part IV.C.

${ }^{26}$ Klaxon Co. v. Stentor Elec. Mfg. Co., 313 U.S. 487, 496 (1941). 
federal courts employing the static approach may at times apply law different from that which would have been applied had the parties litigated their cases in state courts.

This Article suggests that federal courts can largely avoid both the constitutional and the "political and social" defects associated with prediction, abstention, and the static approach by employing a presumption in favor of certifying unsettled questions of state law to the highest court of the state whenever state law authorizes this procedure. ${ }^{27}$ Certification allows federal courts to adjudicate cases presenting unsettled questions of state law in a manner consistent with both judicial federalism and the constitutional separation of powers. First, unlike prediction, certification ensures that agents of the staterather than federal courts-make the policy choices necessary to resolve unsettled questions of state law. Second, unlike abstention, which effectively nullifies federal jurisdiction by ceding all three functions of adjudication (law declaration, fact identification, and law application) to state courts, certification allows federal courts to exercise jurisdiction by at least permitting them to perform fact identification and law application. ${ }^{28}$ Although certification leaves law declaration exclusively to the states, this is precisely where the Judiciary Act of 1789 and the Constitution, as interpreted in Erie, assign this function. Finally, certification avoids the "political and social" defects associated with both prediction and the static approach by maximizing the chances that the same law will be applied in any given case regardless of the accident of diversity jurisdiction.

This Article consists of five parts. Part I begins by observing that state law sometimes fails to provide determinate answers to particular legal questions. Such ambiguity makes it difficult for federal courts to comply with Erie's command to apply state law in the absence of positive federal law governing the question before the court. Part I next examines the suggestion that such ambiguity entitles federal courts to exercise independent judgment to determine the content of state law, and concludes that such an approach is inconsistent with the principles of judicial federalism underlying the Supreme Court's decision in Erie. Part II critically examines the lower federal courts' current practice of resolving unsettled questions of state law by attempting to predict how the highest court of the state would answer

${ }^{27}$ See infra Part V.

${ }^{23}$ See Henry P. Monaghan, Constitutional Fact Review, 85 ColuM. L. REv. 229, 234 36 (1985) (discussing law declaration, fact identification, and law application); infra notes $489-93$ and accompanying text. 
such questions, and explains why this approach likewise raises substantial constitutional concerns in light of the principles of judicial federalism recognized in Erie. Part III describes the potential alternative of abstention and concludes that this approach raises distinct constitutional difficulties based on the separation of powers. Part IV examines a third approach, whereby federal courts refuse to apply a prospective rule of decision unless it has been clearly established by existing sources of state law. Although such a static approach mitigates the judicial federalism and separation-of-powers concerns raised by prediction and abstention, Part IV identifies several distinct disadvantages-based on comity and fairness to the litigants-introduced by this alternative. Finally, Part V examines certification, and concludes that federal courts should employ a presumption in favor of this procedure whenever state law fails to provide a determinate answer to a particular legal question governed by state law. In addition, Part V briefly addresses several potential difficulties that federal courts may encounter in attempting to implement such a presumption.

\section{ERIE, AMBIGUITY, AND INDEPENDENT JUDGMENT}

In Erie Railroad Co. v. Tompkins, ${ }^{29}$ the Supreme Court recognized a constitutional obligation on the part of federal courts to apply "the law of the State" in all cases not governed by positive federal law. "When state law provides a clear answer to the question before the court, this task is relatively straightforward. When existing sources of state law fail to yield a determinate answer to a particular legal question, however, compliance with Erie's command is more difficult. Federal courts may dispose of such cases in several ways, ${ }^{31}$ but most federal courts attempt to predict how the state's highest court would decide the particular question and then apply the resulting rule of decision to the case at bar. ${ }^{32}$ This Part describes the prerequisite for the application of the predictive approach as well as the various alternativessubstantial ambiguity in the meaning or applicability of state law. It next considers an early, but now obsolete, rival to the predictive

${ }^{29} 304$ U.S. 64 (1938).

${ }^{30}$ Id. at 78 (stating that "[e]xcept in matters governed by the Federal Constitution or by Acts of Congress, the law to be applied in any case is the law of the State").

${ }^{31}$ See infra Parts II (predictive approach), III (abstention), IV (static approach), V (certification).

${ }^{32}$ See infra notes $179-93$ and accompanying text. 
approach-independent judicial judgment-and concludes that this alternative raises serious constitutional concerns under the Supreme Court's decision in Erie. In the process, this Part examines Erie and attempts to identify the precise constitutional rationale underlying the Court's decision. This examination suggests that Erie rests on mutually reinforcing principles of federalism and separation of powers that permit state, but not federal, courts to exercise substantial policymaking discretion on behalf of the states.

\section{A. Identifying Indeterminacy in State Law}

In order to comply with Erie's command to apply "the law of the State," federal courts are required to ascertain state law with much greater precision than was the case during the reign of Swift $v$. Tyson. Ascertaining the law of the state is relatively easy when the application of state law yields a clear answer to the precise question before the court. As Professor Greenawalt has explained, "the law often has determinate answers to particular legal questions." ${ }^{34}$ Specifically, "[m]ost often the answer to whether liability of a certain kind arises from an action is no." ${ }^{35}$ In other words, the law simply does not apply, by its terms, to a wide variety of human conduct. For example, it may be bad manners to make a Iunch appointment with a friend and fail to show up, but the law attaches no consequences to such conduct. ${ }^{36}$ Conversely, there are certain "paradigm, clear cases" to which the law unambiguously applies. ${ }^{37}$ Thus, if I attempt to "get even" with my friend for breaking our lunch appointment by intentionally shoving him to the ground, I have committed a common-law battery and will be liable in damages if he chooses to sue. ${ }^{38}$ In either case, Erie merely

${ }^{3 s} 41$ U.S. (16 Pet.) 1 (1842), overruled by Erie, 304 U.S. at 79; see infra notes 82-90 and accompanying text.

34 KENT GREENAWALT, LAW AND OBJECTIVITY 35 (1992).

${ }^{35} I d$.

25 I thank Andrew McBride for suggesting this hypothetical.

${ }^{37}$ H.L.A. HART, THE CONCEPT OF LAW 129 (2d ed. 1994); see id. at 126 (stating that " $[t]$ here will indeed be plain cases constantly recurring in similar contexts to which general expressions are clearly applicable"); see also Paul A. LeBel, Legal Positivism and Federalism: The Certification Experience, 19 GA. L. REV. 999, 1010 (1985) (stating that "[a] settled question of state law is an issue for which there is clear, controlling precedent in the law of the state").

"s The fact that "common law rules do not have canonical formulations," or that "the scope of a rule may be cast in different ways," does not necessarily render the application of such rules indeterminate. GREENAWALT, supra note 34, at 66 . Generally speaking, "all plausible formulations will have some overlapping content," and 
requires federal courts to give effect to determinate answers-liability or no liability - supplied by state law.

When state law fails to provide a determinate answer to a particular legal question, however, a federal court's path is less clear. Generally speaking, state law is indeterminate or ambiguous whenever a particular legal question admits of more than one reasonable answer. ${ }^{39}$ Such indeterminacy may exist in various circumstances. First, a federal court may be asked to decide a particular question that neither the state's highest court nor its lower courts have considered. ${ }^{40}$ Second, a federal court may be asked to decide a question of state law on which the state's highest court has not yet spoken, and on which the state's lower courts have provided insufficient or conflicting guidance. ${ }^{41}$ Third, a federal court may be asked to disregard a prior decision of the state's highest court on the ground that the decision no longer represents the way in which the court would resolve the

"[o]rdinarily the various formulations are cast with certain core situations in mind." Id.

${ }^{39}$ Cf. Chevron U.S.A. Inc. v. Natural Resources Defense Council, Inc., 467 U.S $837,843-44$ (1984) (stating that when a federal "statute is silent or ambiguous with respect to [a] specific issue," federal courts must accept a "reasonable interpretation [of the statute] made by the administrator of an agency"); infra notes 504-16 and accompanying text (discussing Cheuron).

${ }^{40}$ See LeBel, supra note 37, at 1010 (stating that one type of unsettled question of state law "involves an issue that has never been addressed within a system, or at least has never been decided by an appellate court in a way that establishes a rule for lower courts to follow in future cases"). State statutes that have not yet been interpreted by state courts may or may not be indeterminate as applied to various circumstances. Whether the application of a state statute yields a determinate answer to a particular legal question depends in large part on the language of the statute and the background rules of state law that govern the interpretation of state statutes. Cf. Louisiana Power \& Light Co. v. City of Thibodaux, 360 U.S. 25, 30 (1959) (noting that the "statute [in question] has never been interpreted ... and it would not be the first time that the authoritative tribunal has found in a statute less than meets the outsider's eye"). Because state courts sometimes employ idiosyncratic rules of interpretation, "[i]nformed local courts may find meaning [in state statutes] not discernible to the outsider." Id.; see also infra notes 310-18 and accompanying text (discussing Thibodaux).

"Federal courts have adopted various approaches to deciding such cases. For example, some judges in the Northern District of Illinois have held that federal courts are required to follow the decisions of the state appellate court for the district in which the federal court sits. See, e.g., Abbott Lab. v. Granite State Ins. Co., 573 F. Supp. 193, 195 (N.D. Ill. 1983) (stating that "[i]n this Court's view Erie... demands adherence to the Illinois 'internal' choice of law rule that binds a state trial court to the decisions of the Appellate Court in its own district when the Appellate Courts diverge"). Other judges in the same district have held that a federal court must follow whatever approach it thinks would be adopted by the state's highest court. See, e.g., Roberts v. Western-Southern Life Ins. Co., 568 F. Supp. 536, 540 (N.D. Ill. 1983) ("[T]he law we must apply is that which its state supreme court would apply."). 
question today, especially when a substantial period of time has elapsed since the original decision and the trend in other jurisdictions is to the contrary.

According to H.L.A. Hart, some instances of indeterminacy in the law are unavoidable: "Whichever device, precedent or legislation, is chosen for the communication of standards of behaviour, these, however smoothly they work over the great mass of ordinary cases, will, at some point where their application is in question, prove indeterminate; they will have what has been termed an open texture." ${ }^{43}$ The more a particular set of facts diverges from the paradigm case contemplated by a particular rule of decision, the less clear it is that the rule applies and the greater the need for courts to engage in some degree of norm elaboration to resolve the ambiguity. Such "uncertainty at the borderline is the price to be paid for the use of general classifying terms in any form of communication concerning matters of fact." ${ }^{\text {"4 }}$

In these areas of open texture-where existing law fails to provide determinate answers to particular questions-common-law courts frequently exercise policymaking discretion, either explicitly or implicitly, in order to supply a rule of decision that will resolve the case at hand..$^{45}$ On these occasions, courts "confront the issues at stake and can then settle the question by choosing between the competing interests in the way which best satisfies" Justice Holmes thought that courts based their decisions on

${ }^{12}$ See LeBel, supra note 37, at 1010 (stating that some questions are unsettled "even though there has been an authoritative decision on the issue," because "the answer that has been given is, for one reason or another, considered unsatisfactory for contemporary application"). Examples include Mason v. American Emery Wheel Works, 241 F.2d 906, 909-10 (1st Cir. 1957) (predicting that the Mississippi Supreme Court would overrule a thirty-year-old precedent recognizing privity of contract as a prerequisite for product liability in tort), discussed infra notes 283-92 and accompanying text, and Savodnik v. Korvettes, Inc., 488 F. Supp. 822, 825 (E.D.N.Y. 1980) (predicting that the New York Court of Appeals would abandon its traditional "employment at will" doctrine and recognize a new cause of action for the tort of "abusive discharge").

13 HART, supra note 37, at 127-28; cf. THE FEDERALIST No. 37, at 229 (James Madison) (Clinton Rossiter ed., 1961) ("All new laws, though penned with the greatest technical skill and passed on the fullest and most mature deliberation, are considered as more or less obscure and equivocal, until their meaning be liquidated and ascertained by a series of particular discussions and adjudications.").

"HART, supra note 37 , at 128.

${ }^{45}$ See Monaghan, supra note 28, at 236-37 (suggesting that even "law application" often entails a "crucial policy decision: should a further effort at norm elaboration be undertaken?").

${ }^{16}$ HART, supra note 37, at 129. 
"considerations of what is expedient for the community concerned." For this reason, Justice Holmes candidly "recognize[d] without hesitation that judges do and must legislate," but insisted that "they can do so only interstitially."

Justice Holmes believed that filling the interstices in the law required judges "to exercise the sovereign prerogative of choice." Although Justice Holmes regarded the domain of judicial lawmaking as relatively small, ${ }^{50}$ he thought that in cases necessitating such lawmaking, "judges as well as others should openly discuss the legislative principles upon which their decisions must always rest in the end, and should base their judgments upon broad considerations of policy." Thus, in the final analysis, a proper account of the judicial function must acknowledge not only "that the law provides answers to many

${ }^{17}$ Oliver Wendell holmes, The Common LaW 32 (Mark DeWolfe Howe ed., Harvard Univ. Press 1963) (1881).

${ }^{48}$ Southern Pac. Co. v. Jensen, 244 U.S. 205, 221 (1917) (Holmes, J., dissenting).

${ }^{19}$ Oliver Wendell Holmes, Law in Science and Science in Law, 12 HARV. L. REV. 443, 461 (1899). See generally Thomas C. Grey, Molecular Motions: The Holmesian Judge in Theory and Practice, 37 WM. \& MARY L. REV. 19 (1995) (setting forth an insightful account of Justice Holmes's views on judicial lawmaking). "Different legal systems, or the same system at different times, may either ignore or acknowledge more or less explicitly such a need for the further exercise of choice in the application of general rules to particular cases." HART, supra note 37, at 129. Legal formalism, "the orthodox jurisprudence of the bench and the bar, at least until recent times," for example, posits that "[j] udges can and must find existing law that will decide cases in a determinate way." Grey, supra, at 21. In this way, formalism is similar to the declaratory approach described by Blackstone in his Commentaries, and embraced to some extent by federal courts during the Swift era. See infra notes $82-84$ and accompanying text (discussing Swift and Blackstone's Commentaries). A significant effect of the legal culture's widespread acceptance of formalism was "to disguise and to minimize the need for [judicial] choice" in cases of legal indeterminacy. HART, supra note 37, at 129. Rule skepticism, by contrast, a more recent strain of jurisprudential thought, "claim [s] that talk of rules is a myth, cloaking the truth that law consists simply of the decisions of courts and the prediction of them." Id. at 136. H.L.A. Hart was undoubtedly correct in his assessment that "[f]ormalism and rule-scepticism are the Scylla and Charybdis of juristic theory; they are great exaggerations, salutary where they correct each other, and the truth lies between them." Id. at 147; see also GREENAWALT, supra note 34 , at 208 (noting Hart's view).

${ }^{50}$ See Grey, supra note 49, at 35 ("In saying that judges legislate 'interstitially,' rather than simply 'in the gaps,' Holmes was already suggesting that he thought of the gaps as small.").

${ }^{31}$ HOLMES, supra note 47, at 64; of. David L. Shapiro, In Defense of Judicial Candor, 100 HARV. L. REV. 731, 750 (1987) (arguing in favor of judicial candor because "the fidelity of judges to law can be fairly measured only if they believe what they say in their opinions and orders"). 
cases, but that in some difficult cases judges must act like legislators and create new law among 'the gaps.",52

\section{B. Judicial Federalism and Independent Judgment}

The exercise of such policymaking discretion by state courts poses few constitutional difficulties, regardless of the size of the "gap" to be filled. When state law is indeterminate, state courts frequently take it upon themselves to weigh competing policy considerations and fashion rules of decision necessary to decide the case. ${ }^{53}$ As Erie made plain, such lawmaking by state courts "is not a matter of federal concern. ${ }^{.54}$ So long as lawmaking by state courts remains consistent with "a Republican Form of Government," permit states to adopt law in whatever manner they see fit. ${ }^{56}$ Thus, as Erie stressed, as far as federal courts are concerned, "the law of the State" includes not only statutes enacted "by its Legislature," but also law declared "by its highest court in a decision." proach leaves state courts substantially free to make law on behalf of the states.

The Constitution does not afford federal courts the same freedom. To the contrary, as Erie observed, "no clause in the Constitution

${ }^{32}$ GREENAWALT, supra note 34, at 208.

ss In some ways, such lawmaking by state courts to resolve ambiguities in state law is analogous to the lawmaking function performed by administrative agencies when they interpret ambiguous federal statutes. See infra notes 504-16 and accompanying text.

${ }^{34}$ Erie, 304 U.S. at 78.

${ }^{55}$ U.S. CONST. art. IV, § 4. The Supreme Court has generally found this provision of the Constitution to be nonjusticiable. See, e.g., Pacific States Tel. \& Tel. Co. v. Oregon, 223 U.S. 118, 142 (1912) (refusing to adjudicate whether a state government is "republican" because to do so would "obliterate the division between judicial authority and legislative power").

${ }^{36}$ Indeed, the Supreme Court has observed on numerous occasions that the Constitution's strict separation of powers does not apply to the states. See, e.g., Dreyer v. Illinois, 187 U.S. 71, 84 (1902) (stating that "[w] hether the legislative, executive, and judicial powers of a State shall be kept altogether distinct and separate, or whether persons or collections of persons belonging to one department may, in respect to some matters, exert powers which, strictly speaking, pertain to another department of government, is for the determination of the State"); see also Mayor of Philadelphia v. Educational Equal. League, 415 U.S. 605, 615 n.13 (1974) (stating that "[ $t$ ] he Constitution does not impose on the States any particular plan for the distribution of governmental powers"); Sweezy v. New Hampshire, 354 U.S. 234, 255 (1957) (stating that "this Court has held that the concept of separation of powers embodied in the United States Constitution is not mandatory in state governments").

${ }^{57}$ Erie, 304 U.S. at 78. 
purports to confer... power upon the federal courts" to "declare substantive rules of common law applicable in a State. ${ }^{n 8}$ The Supreme Court's denial of power to "declare" substantive rules of common law was not meant to connote the absence of power to ascertain or identify preexisting state-law rules. Power to "declare" rules in this limited sense is necessary for federal courts to comply with Erie's primary command that federal courts apply state law to all matters not "governed by the Federal Constitution or by Acts of Congress." Rather, understood in context, Erie's assertion that federal courts have "no power to declare substantive rules of common law applicable in a State" must be taken to mean that federal courts lack power to exercise the substantial policymaking discretion necessary to fashion or create rules of decision governing matters within the legislative competence of the states. ${ }^{60}$ As discussed more fully below, Erie concluded that law declaration by federal courts in this sense would "invade[] rights which ... are reserved by the Constitution to the several States."

The Supreme Court's embrace of judicial federalism in Erie suggests that federal courts should refrain from exercising substantial policymaking discretion on behalf of the states. From this perspective, the larger the "gap" to be filled, the greater the judicial federalism concerns raised by federal-court formulation of a corresponding rule of decision. ${ }^{62}$ After Erie, however, several courts and commentators initially resisted this reading of the decision and argued that when state law is indeterminate, federal courts should essentially act

${ }^{58} \mathrm{Id}$.

${ }^{59} I d$.

${ }^{\infty}$ Cf. Chevron U.S.A. Inc. v. Natural Resources Defense Council, Inc., 467 U.S. 837,844 (1984) (requiring judicial deference to an agency's interpretation of a statute "whenever decision as to the meaning or reach of a statute ... involve[s] reconciling conflicting policies" (quoting United States v. Shiner, 367 U.S. 374, 382 (1961))); infra notes 504-16 and accompanying text.

${ }^{61}$ Erie, 304 U.S. at 80 . This does not mean that federal courts exercise no policymaking discretion when applying state law. Even strict adherents of the separation of powers acknowledge that "no statute can be entirely precise, and that some judgments, even some judgments involving policy considerations, must be left to the officers executing the law and to the judges applying it." Mistretta v. United States, 488 U.S. 361,415 (1989) (Scalia, J., dissenting); cf. Cheoron, 467 U.S. at 865 (stating that federal "[c]ourts must, in some cases, reconcile competing political interests, but not on the basis of the judges' personal policy preferences"). Thus, some degree of discretion at the margin may be an inescapable feature of the judicial function. At some point, however, the exercise of policymaking discretion can no longer be characterized as merely incidental.

${ }^{62}$ See infra notes $117-36$ and accompanying text. 
like state courts and use independent judgment to fashion state-law rules of decision. Professor Corbin, in particular, challenged the notion that federal courts are not competent to "discover" or "make" state law by reference to "all the data which the state court itself would be free to use. ${ }^{.64}$ According to Professor Corbin, a federal court with jurisdiction over the case "should use the very same juristic data in determining the rights of the litigants" as a state court would use. ${ }^{65}$ Such data "include the state constitution and statutes, former opinions of the state courts of every rank, opinions of the courts of other states, the Restatements of the American Law Institute, the works of juristic writers, [and] the mores and practices of the community. ${ }^{566}$

According to this independent judgment approach, even if there is a complete "absence of precedent" or "the decisions within the particular state are confused and conflicting," "there is law to be discovered and applied, by any court having jurisdiction. ${ }^{n 7}$ Such courts-whether federal or state-should simply employ the customary judicial process that "Anglo-American courts" have always used "[i]n creating our vast, and ever vaster, system of law." ${ }^{\text {"s }}$ This approach leaves federal courts free to take into account "prevailing mores, custom, [and] business practices," ${ }^{, 69}$ and to render decisions "according to the changing needs of men," even if this course creates a conflict "between a federal decision and a state decision." Indeed, according to Professor Corbin, "even if we have a decision of the [state's] highest court, with a clear-cut opinion laying down a definite rule," that court's "rationalizations are not legislative enactments," but "merely "persuasive data" to be considered along with "all those sources of wisdom by which justice is determined." ${ }^{72}$ In other words, a federal court with jurisdiction over a case should use

\footnotetext{
${ }^{6 s}$ Arthur L. Corbin, The Laws of the Several States, 50 YALE L.J. 762, 765 (1941).

Gs. at 771

${ }^{65}$ Id. at 774 .

${ }^{66}$ Id. at 771 .

${ }^{67}$ Id. at 772.

Id. at 771 .

${ }^{69}$ Id. at 775 .

70 Id. at 777 .

${ }^{71} I d$. at 776 .
}

72 Id. at 772; see also id. at 771 ("Even if there are precedents, [courts] may disregard them; and a previously stated rule is one to be distinguished or modified or totally repudiated."). 
independent judgment- "its judicial brains, not a pair of scissors and a paste pot" - "to determine the issues between litigating parties."

Daily v. Parker, ${ }^{75}$ decided seven years after Erie, illustrates Professor Corbin's approach. Children living in Pennsylvania sued a woman residing in Illinois who led their father to abandon them and to deny them further financial support. ${ }^{76}$ The district court dismissed the complaint for failure to state a claim. ${ }^{77}$ The question before the Seventh Circuit was whether a federal court could "recognize and enforce such a cause of action in the absence of any direct holding by the state court upholding such a cause of action." ${ }^{78}$ The Seventh Circuit found such recognition and enforcement to be appropriate. According to the court, as long as the rights claimed have not been denied in state court, federal courts "are free to take the course which sound judgment demands." ${ }^{, 9}$ The Seventh Circuit proceeded to weigh the competing policy considerations, and concluded that "a child today has a right enforceable in a court of law, against one who has invaded and taken from said child the support and maintenance of its father." ${ }^{\prime 00}$ The court defended its approach on the ground that "even in the common law, in 1945, if no precedents be found, courts can hardly be advisedly called radical if they indulge in lawmaking by decisions." ${ }^{81}$ As discussed below, despite its intuitive appeal, the approach advocated by Professor Corbin and employed in Daily is in substantial tension with the constitutional principles underlying the Supreme Court's decision in Erie.

\section{Erie and the Constitutional Structure}

In order to evaluate the independent judgment approach-as well as the various alternatives discussed in the remainder of this Article-it is necessary to identify Erie's constitutional rationale with

73 Id. at 775 .

"Id. at 773; see also Charles E. Clark, State Law in the Federal Courts: The Brooding Omnipresence of Erie v. Tompkins, 55 YALE L.J. 267, 290-95 (1946) (embracing Professor Corbin's approach and pleading "for freedom for the federal judicial process to be judicial").

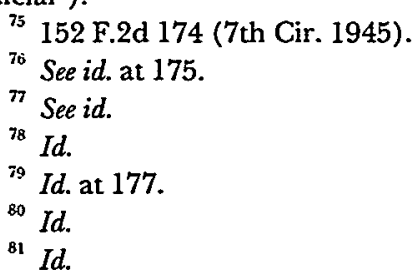


some precision. In Erie, of course, the Supreme Court overruled its prior decision in Swift v. Tyson. ${ }^{82}$ During the so-called Swift era, federal courts claimed the right to exercise independent judgment to determine the content of an ever-expanding list of general commonlaw doctrines, including commercial law, punitive damages, property, and torts. ${ }^{83}$ In these areas, federal courts were free to disregard state court decisions with which they disagreed and to apply their own conceptions of the law. As Erie put it, the Swift doctrine "rest[ed] upon the assumption that there is 'a transcendental body of law outside of any particular State but obligatory within it unless and until changed by statute." ${ }^{84}$

Although this assumption may have been valid with respect to general commercial law at the time Swift was decided, ${ }^{85}$ the federal

${ }^{82} 41$ U.S. (16 Pet.) 1 (1842), overruled by Erie, 304 U.S. at 79.

${ }^{85}$ See Erie, 304 U.S at 75-76 (listing the areas of law that federal courts considered to be part of the "general law").

${ }^{84}$ Id. at 79 (quoting Black \& White Taxicab \& Transfer Co. v. Brown \& Yellow Taxicab \& Transfer Co., 276 U.S. 518, 533 (1928) (Holmes, J., dissenting)). According to Swift, "the decisions of courts" "are, at most, only evidence of what the laws are, and are not, of themselves, laws." Swift, 41 U.S. at 12, 16 Pet. at 18. This conception of general common law drew heavily upon Blackstone's Commentaries, which maintained that common law existed independent of judicial decisions and was based on "natural justice" and "the established custom of the realm." 1 WILLIAM BLACKSTONE, COMmentaries *70, *71; see William R. Casto, The Erie Doctrine and the Structure of Constitutional Revolutions, 62 TUL. L. REV. 907, 913 (1988) (noting that "Swift's intellectual antecedents are easily traced to William Blackstone's Commentaries"). According to prevailing interpretations of Blackstone's Commentaries, common-law judges merely declared the content of a preexisting body of common law; they did not create such law. Thus, according to Blackstone, although "the 'decisions of courts of justice are the evidence of what is common law," "the law, and the opinion of the judge are not always convertible terms, or one and the same thing; since it sometimes may happen that the judge may mistake the law." BLACKSTONE, supra, at *71. When such "mistakes" are discovered, "the subsequent judges do not pretend to make a new law, but to vindicate the old one from misrepresentation." Id. at *70. But of. Albert W. Alschuler, Rediscovering Blackstone, 145 U. PA. L. REV. 1, 36-43, 43 (1996) ("The claim that Blackstone regarded law as fixed for all time, unchangeable and merely awaiting discovery, is a calumny.").

${ }^{85}$ Indeed, "the Court's approach in Swift was quite defensible, when taken in historical context, against the charge that it violated rights reserved to the states." Clark, supra note 4, at 1286; see also RANDALL BRIDWELl \& RALPH U. WHITTEN, THE CONSTITUTION AND THE COMMON LAW 3 (1977) (arguing that "the common law authority of the federal courts as it was actually employed between 1789 and about 1860 is constitutionally justifiable"). This defense is based on the fact that Swift involved a question of general commercial law under the law merchant-a body of customary law derived from the law of nations which neither federal nor state courts considered at the time to consist of sovereign commands. See Swift, 41 U.S. at 12, 16 Pet. at 18 ("It is observable, that the courts of New York do not found their decisions upon this point, upon any local statute, or positive, fixed or ancient local usage; but they deduce the 
courts' subsequent adherence to-and expansion of-the Swift doctrine raised increasingly troubling constitutional concerns in light of two developments. First, at some point, "[s] tate courts no longer conceived of their task in commercial cases as applying a [customary] body of law common to many jurisdictions. Rather, they increasingly claimed or exercised authority to formulate commercial doctrines as a matter of state law. ${ }^{86}$ Second, federal courts not only continued to exercise independent judgment with respect to general commercial law notwithstanding this shift, but also "vastly expanded the range of legal questions subject to the Swift doctrine" to include "such historically local matters as punitive damages, property, and torts." "These two developments created an ever-widening legitimacy gap." ${ }^{\text {88 }}$ As Professor Lawrence Lessig has observed, by the time Erie was decided, changing conceptions of state law revealed the "political reality" that "what a judge was doing when he decided an open question of common law was making law rather than finding law.." ${ }^{89}$ As discussed more fully below, such open-ended lawmaking by federal courts under Swift raised substantial federalism and separation-of-powers concerns because, to the extent that "these matters were predomi-

doctrine from the general principles of commercial law."); Clark, supra note 4, at 128385,1285 (stating that "both federal and state courts regarded the question at issue in Swift... as arising under the general law merchant rather than under distinctively state (or federal) law"). The federal courts' application of customary law in cases like Swift did not raise significant federalism concerns because, at the time, both federal and state courts approached such law as a preexisting body of customs used to govern commercial transactions generally, regardless of location. See id. at 1285-86 (noting that New York courts "appeared to be applying the law of nations"). For similar reasons, the application of customary law by federal courts did not raise significant separation-of-powers concerns because such courts "were not engaged in unrestrained judicial lawmaking," id. at 1287, and the Framers clearly contemplated that federal courts would apply "the various branches of the law of nations" in many of the cases and controversies to which the Article III judicial power extends, id. at 1288. For an excellent historical analysis of these issues, see BRIDWELI \& WHITTEN, supra, at 61-97.

${ }^{86}$ Clark, supra note 4, at 1290.

${ }^{87}$ Id.; see TONY FREYER, HARMONY \& DISSONANCE: THE SWFT \& ERIE CASES IN AMERICAN FEDERALISM 71 (1981) (stating that "the federal judiciary continued to enlarge the body of general law so that by 1890 it included some 26 doctrines").

${ }^{88}$ Clark, supra note 4, at 1291.

${ }^{89}$ Lawrence Lessig, Understanding Changed Readings: Fidelity and Theory, 47 STAN. L. REv. 395, 431 (1995) [hereinafter Lessig, Understanding Changed Readings]; see also Lawrence Lessig, Erie-Effects of Volume 110: An Essay on Context in Interpretive Theory, 110 HARV. L. REV. 1785, 1794-95 (1997) [hereinafter Lessig, Erie-Effects of Volume 110] (stating that " $[t] o$ the extent that it became implausible to attribute the substance of federal general common law elsewhere, to the extent this law 'finding' seemed more and more like law 'making,' the actions of the judges articulating this law increasingly appeared, in this sense, political"). 
nantly matters of state common law... it now seemed both as if federal courts were exercising the power of state legislatures, and as if federal courts were exercising the power of state legislatures."

Debate has long raged over the precise nature of the constitutional defect relied upon by the Court in Erie, and even the necessity of reaching the constitutional question. ${ }^{91}$ Some commentators have characterized the Court's constitutional analysis as dictum, and have suggested that the decision in Erie is best regarded as resting solely on the Court's expansive reading of section 34 of the Judiciary Act of 1789, also known as the Rules of Decision Act. ${ }^{92}$ Although the Erie Court did initially examine section 34 and conclude that "the construction given to it by the [Swift] Court was erroneous, ${ }^{, 93}$ the Court expressly declined to rest its decision on that ground. According to the Court: "If only a question of statutory construction were involved, we should not be prepared to abandon a doctrine so widely applied throughout nearly a century. But the unconstitutionality of the course pursued has now been made clear and compels us to do so." ${ }^{94}$ Thus, if Erie is to be taken at its word, it is the Court's statutory interpretation-rather than its constitutional analysis-that constitutes dictum.

As for the precise nature of the constitutional defect itself, some commentators have suggested that the equal protection "component" of the Fifth Amendment supplies a plausible basis for the Court's decision, relying on the Court's assertion that "the [Swift] doctrine

${ }^{90}$ Lessig, Understanding Changed Readings, supra note 89, at 431. In explaining the Supreme Court's decision in Erie, Professor Lessig emphasizes that "in the seventy-five years immediately prior to Erie, [both] the practice of federal general common law, and the content of federal general common law, changed." Lessig, Erie-Effects of Volume 110 , supra note 89 , at 1792 . According to Professor Lessig, "[b]oth changes changed the meaning of Swift." Id.

${ }^{91}$ See ERIIN CHEMERINSKY, FEDERAL JuRISDiction § 5.3, at 299 (2d ed. 1994) (stating that " $[t]$ he constitutional basis for the Erie decision has confounded scholars").

$\$ 28$ U.S.C. \$ 1652 (1994); see Clark, supra note 74, at 278 (noting that Justice Brandeis's remark that overruling the Swift doctrine was compelled by the "unconstitutionality of the course" pursued during the post-Swift era "surely seems" to be dictum (quoting Erie, 304 U.S. at 77-78)); Letter from Chief Justice Harlan Fiske Stone to Associate Justice Owen J. Roberts (Jan. 3, 1941) (referring to Erie's constitutional analysis as "unfortunate dicta"), quoted in ALPHEUS THOMAS MASON, HARLAN FISKE STONE: PILLAR OF THE LAW 480 n.† (1956).

${ }^{93}$ Erie, 304 U.S. at 72.

Id. at 77-78 (emphasis added) (footnote omitted); see CHEMERINSKY, supra note $91, \S 5.3$, at 299 (stating that "Justice Brandeis made it clear that the constitutional argument was integral to the Court's holding" in Erie). 
rendered impossible equal protection of the law. ${ }^{, 95}$ The difficulty with this account is that it appears to be foreclosed both by a careful reading of the Court's opinion and by the limited scope of the Fifth Amendment at the time Erie was decided. The Court's reference to "equal protection" appears in a preliminary section of its opinion describing the "political and social" defects ${ }^{96}$ associated with the Swift doctrine rather than in the section specifically addressing "the unconstitutionality of the course pursued. ${ }^{.97}$ Moreover, although Erie noted that " $[t]$ he injustice and confusion incident to the doctrine of Swift $v$. Tyson have been repeatedly urged as reasons for abolishing or limiting diversity of citizenship jurisdiction, ${ }^{, 98}$ the Court expressly declined to rest its decision on those grounds. ${ }^{99}$ Finally, the Supreme Court did not even recognize that the Fifth Amendment contained an equal protection component until at least six years after its decision in Erie. ${ }^{100}$ These circumstances, taken singly or in combination, appear to foreclose the conclusion that Erie rests on equal protection principles. $^{101}$

A closer reading of Erie reveals that the Supreme Court's decision rests on judicial federalism-an important aspect of the constitutional

${ }^{95}$ Erie, 304 U.S. at 75; see John R. Leathers, Erie and Its Progeny as Choice of Law Cases, 11 Hous. L. REv. 791, 795-96 (1974) (proposing the Fifth Amendment's equal protection component as a possible basis for the Court's decision in Erie).

${ }^{96}$ Erie, 304 U.S. at 74. These "political and social" defects included making "rights enjoyed under the unwritten 'general law' vary according to whether enforcement was sought in the state or in the federal court." Id. at 74-75. Such variance created two "mischievous results": it permitted noncitizens to select whether so-called questions of general law would be adjudicated in federal or state court, and it "prevented uniformity in the administration of the law of the State." Id.

${ }^{97}$ Id. at 77-78.

Id. at 77 .

${ }^{99}$ See id. at 77-78 (relying on the "unconstitutionality of the course pursued" by post-Swift federal courts to overrule the Swift doctrine).

${ }^{100}$ See Korematsu v. United States, 323 U.S. 214 (1944) (subjecting military segregation of Japanese-Americans to equal protection scrutiny). Prior to Korematsu, the Supreme Court did not entertain equality-based claims under the Fifth Amendment. The Court's 1921 response to a taxpayer's challenge to a discriminatory federal tax is representative: "Reference is made to cases decided under the equal protection clause of the Fourteenth Amendment; but clearly they are not in point. The Fifth Amendment has no equal protection clause; and the only rule of uniformity prescribed [for congressional tax laws] is the territorial uniformity required by Art. I, § 8." LaBelle Iron Works v. United States, 256 U.S. 377, 392 (1921) (citations omitted).

${ }^{101}$ See CHEMERINSKY, supra note 91, $\$ 5.3$, at 299 (stating that Erie's reference to equal protection "appears to be a rhetorical rather than a constitutional argument because the Supreme Court had not yet applied the requirements of equal protection to the federal government"). 
structure derived from the mutually reinforcing principles of federalism and separation of powers. The Court's application of judicial federalism was facilitated by its decision to view state law through the lens of legal positivism and to abandon older, declaratory theories of common law. As the Court itself later acknowledged, "[i]n overruling Swift $v$. Tyson, Erie... did not merely overrule a venerable case. It overruled a particular way of looking at law ...."102 As discussed below, however, Erie did not adopt legal positivism as an end in itself. Rather, the Court invoked positivism only as a means of implementing the principles of judicial federalism underlying the constitutional structure.

In particular, Erie embraced two tenets of legal positivism that helped the Court both to identify and ultimately to resolve the constitutional difficulties raised by the federal courts' continued adherence to the Swift doctrine. First, Erie accepted "one of the most important implications of classical positivism"- "that law was the product of human will, whether by legislation or judicial discretion." ${ }^{103}$ Second, Erie adopted the positivist position, championed by Justice Holmes, that law consists exclusively of sovereign commands. According to the Court:

The fallacy underlying the rule declared in Swift $v$. Tyson is made clear by Mr. Justice Holmes. The doctrine rests upon the assumption that there is "a transcendental body of law outside of any particular State but obligatory within it unless and until changed by statute,"...: "[B]ut law in the sense in which courts speak of it today does not exist without some definite authority behind it." ${ }^{104}$

${ }^{102}$ Guaranty Trust Co. v. York, 326 U.S. 99, 101 (1945) (citation omitted).

${ }^{105}$ Anthony J. Sebok, Misunderstanding Positivism, 93 MicH. L. REv. 2054, 2083 (1995). This aspect of the Court's opinion "can also be seen as influenced by legal realism," because "the realists had shown that the common law of tort had to be made, not found." Akhil Reed Amar, Law Story, 102 HARV. L. REV. 688, 695 (1989) (book review); see also Larry Kramer, The Lawmaking Power of the Federal Courts, 12 PACE L. REV. 263, 283 (1992) ("Erie's real significance is that it represents the Supreme Court's formal declaration that [Swift's] view of the common law... is dead, a victim of positivism and realism."); Lawrence Lessig, Fidelity and Constraint, 65 FORDHAM L. REV. 1365, 1408 \& n.129 (1997) (suggesting that Erie was "[p]remised on a change in philosophy").

${ }^{104}$ Erie, 304 U.S. at 79 (footnote omitted) (quoting Black \& White Taxicab \& Transfer Co. v. Brown \& Yellow Taxicab \& Transfer Co., 276 U.S. 518, 533 (1928) (Holmes, J., dissenting)); see also Patrick J. Borchers, The Origin of Diversity Jurisdiction, the Rise of Legal Positivism, and a Brave New World for Erie and Klaxon, 72 TEX. L. REV. 79, 116 (1993) (noting that " $[t]$ he positivist conception of law, derived largely from John Austin's lectures on jurisprudence, defined law as a command of a sovereign"). 
Because these tenets revealed that federal courts at the end of the Swift era were both disregarding an important source of state law and making what was in effect a form of federal law, Erie's embrace of positivism "virtually dictated the overruling of Swift $v$. Tyson and the creation of the Erie doctrine." 105

The Supreme Court's acceptance of the first tenet revealed the "political reality" that "[c]ommon law lawfinding was common law lawmaking." ${ }^{106}$ Whatever the situation was when the Court decided Swift, it was now clearly understood that state courts no longer approached their task in commercial cases as the application of a preexisting body of customary law common both to many states and, indeed, to the entire "mercantile world." ing torts and property, for example, state courts now perceived their decisions to constitute a source of state law endemic to their respective states. ${ }^{108}$ As the Court put it in Erie.

"The common law so far as it is enforced in a State, whether called common law or not, is not the common law generally but the law of that State existing by the authority of that State without regard to what it may have been in England or anywhere else. ${ }^{109}$

The Court's recognition that state courts make law on behalf of the states established a necessary predicate for the Court's further conclusion that, as far as federal courts are concerned, both state statutes and state-court precedents constitute commands of the state sovereign and therefore constitute equally valid sources of state law. Thus, according to the Court, "whether the law of the State shall be declared by its Legislature in a statute or by its highest court in a decision is not a matter of federal concern."

The Supreme Court's embrace of the second tenet-that law consists exclusively of sovereign commands-required the Court to confront whether so-called "general common law" constitutes state or federal law. Relying on the fact that "no clause in the Constitution

${ }^{105}$ Casto, supra note 84, at 908 (footnote omitted); see also Borchers, supra note 104 , at 115-16 (stating that "the change that finally brought about Erie was a revolution in legal philosophy").

${ }^{106}$ Lessig, Understanding Changed Readings, supra note 89, at 431.

${ }^{107}$ Coddington v. Bay, 20 Johns. 637, 651 (N.Y. 1822) (Spencer, C.J.).

${ }^{103}$ See Clark, supra note 4, at 1290 (arguing that “[s] tate courts no longer conceived of their task in commercial cases as applying a general body of law common to many jurisdictions").

${ }^{109} 304$ U.S. at 79 (quoting Black $\mathcal{F}^{2}$ White Taxicab, 276 U.S. at 533-34 (Holmes, J., dissenting)).

${ }^{\text {"Io }} I d$. at 78 . 
purports to confer... power upon the federal courts" "to declare substantive rules of common law applicable in a State," the Erie Court concluded that " $[\mathrm{t}]$ here is no federal general common law." Rather, general common law ordinarily should be regarded as a form of state law. ${ }^{112}$ Accordingly, the precise contours of such law must be fashioned by agents of the state. As the Court put it, "the authority and only authority is the State, and if that be so, the voice adopted by the State as its own [whether it be of its Legislature or of its Supreme Court] should utter the last word. ${ }^{m 113}$

The Supreme Court's embrace of legal positivism, however, is not sufficient to explain the Court's decision. Unmitigated application of legal positivism would suggest that the decisions of federal courts on questions of general law constitute a form of federal law. Just as state courts' decisions on questions of general law make law on behalf of the state sovereigns, federal courts' decisions on such questions could

${ }^{111}$ Id.

112 As discussed below, this conclusion derives support from various aspects of the constitutional structure, at least with respect to matters within the legislative competence of the states. See infra notes 117-36 and accompanying text. On the other hand, there appear to be at least some matters traditionally governed by general law or the law of nations-such as the rights of foreign ambassadors and rules of decision in prize cases-that the Constitution places beyond the legislative competence of the states. See generally Clark, supra note 4, at 1311-21, 1332-40 (noting, for example, that "the rights of diplomats in transit do not fall within the legislative competence of the states"). In light of the Constitution's allocation of exclusive power over foreign affairs to the federal government, there is reason to suppose that "the Court did not have rules like [these] in mind when it decided Erie" Banco Nacional de Cuba v. Sabbatino, 376 U.S. 398, 425 (1964); see Clark, supra note 4, at 129499 (suggesting that the resolution of matters integral to the foreign relations of the United States is "committed by the Constitution to the exclusive authority of the federal government").

${ }^{115}$ Erie, 304 U.S. at 79 (alteration in original) (quoting Black $\mathcal{E}$ White Taxicab, 276 U.S. at 532-34 (Holmes, J., dissenting)). One might inquire whether Erie's reliance on legal positivism is legitimate given that the Framers undoubtedly viewed the common law through a different jurisprudential lens. See supra note 84 (describing Blackstone's conception of common law). At least in this context, the Court's limited use of positivism appears to be appropriate. As discussed in the text, the Court did not attempt to impose legal positivism without regard to the constitutional structure. Rather, the Court merely employed positivism as a convenient means of revealing the "political reality" that by 1938 , state courts were engaged in substantial lawmaking on behalf of their respective states. Lessig, Understanding Changed Readings, supra note 89 , at 431 . This revelation permitted the Court to implement principles of judicial federalism by requiring federal courts generally to respect such lawmaking by state courts. At the same time, however, the Erie Court remained faithful to the constitutional structure by refusing to employ positivism to justify lawmaking by federal courts. See infra notes $114-36$ and accompanying text. 
be said to make law on behalf of the federal sovereign. ${ }^{114}$ Both forms of judge-made law comply with the tenets of legal positivism adopted in Erie because both forms of law result from the exercise of discretion by agents acting on behalf of a particular sovereign. Thus, had the Court's overriding objective in Erie been to implement a positivist conception of law, the case might have come out differently. Under this scenario, the Court presumably would have concluded that law adopted by federal courts on behalf of the federal sovereign constitutes a form of federal law, and that federal judge-made law takes precedence over contrary state law. ${ }^{115}$

Significantly, the Supreme Court did not reach this conclusion in Erie. Rather, the Court overruled Swift and declared that " $[t]$ here is no federal general common law." Thus, in word and deed, the Erie Court refused to invoke positivism to justify lawmaking by federal courts. This limitation on the use of legal positivism was compelled by a basic feature of the constitutional structure-judicial federalism. ${ }^{117}$ Judicial federalism refers to the lack of constitutional power on the part of the federal courts-acting independent of the political branches-to adopt substantive law applicable in the states. ${ }^{11}$ In a

${ }^{114}$ Cf. George Rutherglen, Reconstructing Erie: A Comment on the Perils of Legal Positivism, 10 CONST. COMMENTARY 285, 292 (1993) (stating that if Justice Brandeis "found all judicial decisions backed by state power to be law, he would have had to recognize that the federal general common law was backed by political power-not of the states, but of the federal government-so that it, too, was a source of law").

${ }^{115}$ Positivist arguments of this kind in fact have been urged in support of broad federal common lawmaking power by federal courts. See Martha A. Field, Sources of Law: The Scope of Federal Common Law, 99 HARV. L. REV. 881, 983 (1986) (suggesting that federal courts have power to fashion and apply federal common-law rules "whenever federal interests require a federal solution"); Henry J. Friendly, In Praise of Erie-And of the New Federal Common Law, 39 N.Y.U. L. REV. 383, 422 (1964) (describing the "complementary concepts... that federal courts must follow state decisions on matters of substantive law appropriately cognizable by the states whereas state courts must follow federal decisions on matters within national legislative power where Congress has so directed"); Louise Weinberg, Federal Common Law, 83 Nw. U. L. REV. 805, 805 (1989) (stating that "there are no fundamental constraints on the fashioning of federal rules of decision"). Although such power may be consistent with the abstract principles of legal positivism identified in Erie, it is in substantial tension with the constitutional structure. See Clark, supra note 4, at 1268-70; infra notes 120-36 and accompanying text.

${ }^{116}$ Erie, 304 U.S. at 78.

117 Cf. Rutherglen, supra note 114, at 295 (stating that "the positivist argument in the Erie opinion" must "be supported by other arguments of constitutional structure," and thus "must be narrowed from an attack on all forms of judge-made law to a defense of the binding force of state judicial decisions").

${ }^{118}$ See Erie, 304 U.S. at 78 (stating that "no clause in the Constitution purports to confer ... power upon the federal courts" "to declare substantive rules of common law 
sense, judicial federalism reflects a constitutional "rule of recognition" that limits when a rule proposed by an agent of the federal government may be given the force of "law" in federal court."

The Supreme Court recognized such a limitation in Erie. The Court began its constitutional analysis by asserting that "[e]xcept in matters governed by the Federal Constitution or by Acts of Congress, the law to be applied in any case is the law of the State."120 Under this formulation, only certain forms of federal law-the Constitution, acts of Congress, and presumably treaties-suffice to displace state law. ${ }^{121}$

applicable in a State whether they be local in their nature or 'general,' be they commercial law or a part of the law of torts"). The Court also prominently asserted that "Congress has no power to declare substantive rules of common law applicable in a State." Id. In light of the Court's contemporaneous decisions broadly interpreting Congress's power under the Commerce Clause, see Wickard v. Filburn, 317 U.S. 111, 118 (1942) (upholding Congress's regulation of wheat production "not intended in any part for commerce but wholly for consumption on the farm"); NLRB v. Jones \& Laughlin Steel Corp., 301 U.S. 1, 43 (1937) (holding that burdens upon interstate commerce are within the reach of Congress, including acts which grow out of labor disputes), the Court's suggestion that Congress lacks power to prescribe a rule of decision in a case like Erie seems dubious, see Clark, supra note 4, at 1258 (questioning the Erie Court's suggestion "that Congress lacks power to regulate the duty of care" in light of the decisions in Wickard and Jones \& Laughlin); Paul J. Mishkin, Some Further Last Words on Erie-The Thread, 87 HARV. L. REV. 1682, 1684 n.10 (1974) ("It would seem reasonably clear that even by then contemporary standards, Congress would have been seen as having power to prescribe a substantive rule of liability for the specific accident in Erie"). In any event, the Court's assertion concerning lack of congressional power was dictum because no federal statute purported to prescribe a federal rule of decision in Erie. For these reasons, "the constitutional argument of Erie has since been reinterpreted to emphasize the distinction-at least implicit in the opinion-between the power of Congress and the power of the federal courts." Rutherglen, supra note 114, at 288. In other words, as Professor Currie has observed:

[O]n the facts of the case the more serious objection seemed to be one less of federalism than of separation of powers: whether or not Congress could make rules to govern the particular case, it had not done so; and the federal courts had only those powers given them by the Constitution or statute.

DAVID P. CURRIE, THE CONSTITUTION IN THE SUPREME COURT: THE SECOND CENTURY 1888-1986, at 243 (1990).

119 See HART, supra note 37, at 94 (stating that a "rule of recognition" operates to "specify some feature or features possession of which by a suggested rule is taken as conclusive affirmative indication that it is a rule of the group to be supported by the social pressure it exerts"). For a thoughtful examination of the nature and source of the rules of recognition in the United States, see Kent Greenawalt, The Rule of Recognition and the Constitution, 85 MiCH. L. REV. 621 (1987).

${ }^{120}$ Erie, 304 U.S. at 78.

${ }^{121}$ See Henry P. Monaghan, Book Review, 87 HARV. L. REv. 889, 892 (1974) (stating that "Erie is, fundamentally, a limitation on the federal court's power to displace state law absent some relevant constitutional or statutory mandate which neither the general language of article III nor the jurisdictional statute provides"); $c f$. U.S. CONST. art. VI, cl. 2 ("This Constitution, and the Laws of the United States which shall be 
Unless a federal court finds that such "positive" federal law governs, the court must apply the law of the state. The "law of the State," in sharp contrast, may be "declared by its Legislature in a statute or by its highest court in a decision." tutional disparity-derived from the constitutional structurebetween the powers of state and federal courts to make law on behalf of their respective sovereigns. Although the Erie Court concluded that the manner in which states make state law is not a matter of federal concern," the same conclusion cannot be reached with respect to the means by which the federal government makes "law applicable in a State. ${ }^{123}$ The latter is necessarily "a matter of federal concern" because the Constitution not only limits the powers available to the federal government, but also carefully specifies-and thereby restricts-the manner in which the federal government may exercise its powers.

Thus, not only does "no clause in the Constitution purport[] to confer [lawmaking] power upon the federal courts, ${ }^{, 24}$ but the Constitution actually establishes several specific "rules of recognition" that vest power to adopt various forms of federal law in other federal actors. These provisions impose detailed procedural safeguards inconsistent with lawmaking by federal courts. For example, the Constitution requires that every "Bill," "Order, Resolution, or Vote," "before it [shall] become a Law," be approved either by both houses of Congress and the President, or by two-thirds of both houses. ${ }^{125}$ Similarly, the Constitution requires the President "to make Treaties" "by and with the Advice and Consent of the Senate." Finally, the Constitution specifies that before a proposed constitutional amendment "shall be valid ... as Part of this Constitution," it must be adopted according to the procedures set forth in Article V, which contemplate action by both Congress and a supermajority of the states.

made in Pursuance thereof; and all Treaties made, or which shall be made, under the Authority of the United States, shall be the supreme Law of the Land; and the Judges in every State shall be bound thereby, any Thing in the Constitution or Laws of any State to the Contrary notwithstanding.").

${ }^{122}$ Erie, 304 U.S. at 78.

${ }^{123} I d$.

${ }^{124} \mathrm{Id}$.

${ }^{125}$ U.S. CONST. art. I, $\$ 7$.

${ }^{126}$ Id. art. II, \$ 2, cl. 2.

${ }^{127}$ Id. art. V. As Professor Monaghan has recently explained, "Article V was designed to permit a very small number of states (currently thirteen) containing but a 
These are the only procedures set forth in the Constitution by which agents of the federal government may adopt "law applicable in a State." Significantly, none of these constitutional procedures either requires or permits participation by the federal judiciary. This was no accident. ${ }^{128}$ As Professor Peterson has observed, " $[t]$ he framers did not grant [federal] judges the right to exercise their own unlimited discretion or will instead of judgment." ${ }^{229}$ To the contrary, they specifically "relied on the fact that [federal] judges do not possess the same kind of primary discretion as legislators." ${ }^{130}$ Thus, although it is customary to refer to federal action that exceeds the scope of federal power as violating constitutional principles of federalism, Erie recognizes that federal action that violates the Constitution's separation of powers-or the various procedural safeguards designed to check the exercise of federal power-may likewise "invade[] rights

fraction of the total national population to block constitutional change." Henry Paul Monaghan, We the People[s], Original Understanding, and Constitutional Amendment, 96 Colum. L. REv. 121, 125 (1996). Accordingly, "Article V was a vital part of a larger design that ensured that, in the new constitutional order, the individual states would remain independent and important political communities, and that the terms of their union with one another could be altered only if substantial obstacles were overcome." Id. at 130 .

${ }^{128}$ Specifically, the Constitutional Convention repeatedly considered and rejected Edmund Randolph's proposal to establish a council of revision consisting of "the Executive and a convenient number of the National Judiciary ... with authority to examine every act of the National Legislature before it shall operate." James Madison, Notes on the Constitutional Convention (May 29, 1787), in 1 THE RECORDS OF THE FEDERAL CONVENTION OF 1787, at 21 (Max Farrand ed., 1911) [hereinafter RECORDS] (paraphrasing Mr. Randolph's proposed resolutions). Disapproval by the council would have "amount[ed] to a rejection" of the proposed legislation unless a supermajority in each house reenacted it. See id. The Convention rejected Randolph's proposal on the ground that it made "the Expositors of the Laws, the Legislators which ought never to be done." James Madison, Notes on the Constitutional Convention (July 21, 1787), in 2 RECORDS, supra, at 75 (paraphrasing statements of Mr. Gerry); see also id. ("Mr. Strong thought with Mr. Gerry that the power of making ought to be kept distinct from that of expounding, the laws. No maxim was better established.").

${ }^{129}$ Todd D. Peterson, Restoring Structural Checks on Judicial Power in the Era of Managerial Judging, 29 U.C. DAVS L. REV. 41, 53 (1995) (citing THE FEDERALIST NO. 78, at 526 (Alexander Hamilton) (Jacob E. Cooke ed., 1961)).

${ }^{130}$ Id. As Professor Peterson has explained, the founders believed that federal judges would "not [be] able to exercise unconstrained power" consistent with the limited nature of the federal judicial power. Id. For example, Professor Peterson points out:

In defending the independent judiciary, Hamilton expressly relied on the power of precedent as a check on judicial power: "To avoid an arbitrary discretion in the courts, it is indispensable that they should be bound down by strict rules and precedents, which serve to define and point out their duty in every particular case that comes before them ...."

Id. (quoting THE FEDERALIST NO. 78, supra note 129, at 529). 
which ... are reserved by the Constitution to the several States." ${ }^{\text {131 }}$ In this way, the Constitution "reserves substantive lawmaking power to the states and the people both by limiting the powers assigned to the federal government and by rendering that government frequently incapable of exercising them." ${ }^{132}$

Permitting federal courts unilaterally to fashion and apply "substantive rules of common law applicable in a State"-even rules like those applied during the Swift era that are not binding in state court - would enable federal courts to circumvent the carefully drawn checks and balances that the Constitution establishes to govern the federal government's adoption of "law applicable in a State." Such lawmaking by federal courts would undermine the constitutional "'autonomy and independence of the States.",133 Thus, the separation of legislative and judicial powers reflected generally in the Constitu-

${ }^{131}$ Erie, 304 U.S. at 80; see Clark, supra note 4, at 1261 (stating that Erie demonstrates that "federal action that violates the Constitution's separation of powers may also "invade[] rights which ... are reserved by the Constitution to the several States" (quoting Erie, 304 U.S. at 80)). Professor Lessig has made a similar point:

More and more it seemed both that federal courts were exercising the power of state legislatures (a federalism concern revealed by positivism), and that federal couts were exercising the power of state legislatures (a separation of powers concern, revealed by realism). This meant, under Holmes's view of what the common law was, that federal courts were exceeding constitutional limits, twice over.

Lessig, supra note 103, at 1406-07 (footnotes omitted).

${ }^{192}$ Clark, supra note 4, at 1260-61. These judicial federalism concerns apply only to matters over which the states possess legislative competence, like those at issue in Swift and Erie. With respect to matters that the Constitution entrusts exclusively to the federal government-such as the United States' conduct of foreign relations-any improper lawmaking by federal courts would raise only separation-of-powers concerns. See id. at 1272-74 (suggesting that federal common-law rules frequently govern matters beyond the legislative competence of the states and thus raise few federalism concerns). For this reason, many modern federal common-law rules raise far fewer federalism concerns than the general common-law rules at issue in Erie, because the former, unlike the latter, frequently govern matters beyond the legislative competence of the states. See id. at 1274 ("If the matters fall beyond the legislative competence of the states, then the principles of judicial federalism recognized in Erie do not function as a serious constraint on the federal courts' application of 'federal judge made law."

${ }^{133}$ Erie, 304 U.S. at 78 (quoting Baltimore \& Ohio R.R. Co. v. Baugh, 149 U.S. 368, 401 (1893) (Field, J., dissenting)); $c f$. id. at 79 ("Supervision over either the legislative or judicial action of the States is in no case permissible except as to matters by the Constitution specifically authorized or delegated to the United States. Any interference with either, except as thus permitted, is an invasion of the authority of the State, and, to that extent, a denial of its independence." (quoting Baugh, 149 U.S. at 401 (Field, J., dissenting))). 
tion, ${ }^{134}$ and specifically in the procedures governing adoption of the various forms of positive federal law, ${ }^{135}$ confirms Justice Stevens's assessment on behalf of the Supreme Court that "federal courts, unlike their state counterparts, are courts of limited jurisdiction that have not been vested with open-ended lawmaking powers." ${ }^{136}$

Two lines of post-Erie Supreme Court precedents appear to confirm Erie's conception of judicial federalism. ${ }^{137}$ Like Erie, these cases suggest that federal courts-as opposed to the political brancheslack power to adopt or displace substantive rules of common law applicable in a state. First, open-ended lawmaking by federal courts would undermine the operation of what Professor Herbert Wechsler referred to as "the political safeguards of federalism." ${ }^{\text {"1s }}$ Professor Wechsler suggested that federal courts need not strictly police the boundaries of the powers delegated to the federal government because the states' interests are adequately represented by their ability to influence the selection of Congress and the President. ${ }^{139}$ The

${ }^{194}$ Compare U.S. CONST. art. I, § 1 ("All legislative Powers herein granted shall be vested in a Congress of the United States, which shall consist of a Senate and a House of Representatives."), with id. art. III, $\S 1$ ("The judicial Power of the United States, shall be vested in one supreme Court, and in such inferior Courts as the Congress may from time to time ordain and establish."). The founders consciously rejected the practice employed by several states, during both the colonial and Confederation eras, of combining legislative and judicial authority in the same hands. See, e.g., THE FEDERALIST NOS. 47, 48 (James Madison) (describing the Framers' conception of the separation of powers); M.J.C. VILE, CONSTITUTIONALISM AND THE SEPARATION OF POWERS 119-75 (1967) (describing various influences on the development of the separation-of-powers doctrine); GORDON S. WOOD, THE CREATION OF THE AMERICAN REPUBLIC: 1776-1787, at 154, 549-50 (1969) (contrasting the views of separation of powers during various stages of the eighteenth century).

${ }^{135}$ Significantly, the Constitution invariably requires the participation of multiple actors in order to create federal law. The establishment of such "checks and balances" reflects the Framers' view that "the greater the diversity in the situations of those who are to examine it, the less must be the danger of those errors which flow from want of due deliberation, or of those missteps which proceed from the contagion of some common passion or interest." THE FEDERALIST No. 73, at 443 (Alexander Hamilton) (Clinton Rossiter ed., 1961).

${ }^{135}$ Northwest Airlines, Inc. v. Transport Workers Union, 451 U.S. 77, 95 (1981); see also Atherton v. FDIC, 117 S. Ct. 666, 670 (1997) ("'Whether latent federal power should be exercised to displace state law is primarily a decision for Congress,' not the federal courts." (quoting Wallis v. Pan Am. Petroleum Corp., 384 U.S. 63, 68 (1966))).

${ }^{137}$ Compare Garcia v. San Antomio Metropolitan Transit Authority, 469 U.S. 528 (1985), discussed infra notes 140-43 and accompanying text, with Hanna v. Plumer, 380 U.S. 460 (1965), discussed infra notes 161-62 and accompanying text.

${ }^{\text {iss }}$ Wechsler, supra note 13 (quoting from the title).

${ }^{139}$ See id. at 544 ("The actual extent of central intervention in the governance of our affairs is determined far less by the formal power distribution than by the sheer 
Supreme Court essentially embraced Professor Wechsler's thesis in 1985, when it decided Garcia v. San Antonio Metropolitan Transit Authority ${ }^{140}$ and overruled National League of Cities v. Usery. ${ }^{141}$ Citing Wechsler, the Court declared:

[T] he principal means chosen by the Framers to ensure the role of the States in the federal system lies in the structure of the Federal Government itself. It is no novelty to observe that the composition of the Federal Government was designed in large part to protect the States from overreaching by Congress.

Accordingly, the Court eschewed judicial enforcement of constitutional limits on Congress's power to regulate the states and concluded that "the principal and basic limit on the federal commerce power is that inherent in all congressional action-the built-in restraints that our system provides through state participation in federal governmental action." ${ }^{143}$

Since Garcia, debate has continued over whether the political safeguards of federalism should be regarded as the exclusive means of policing federal power or whether judicial review has a role to play as well. ${ }^{144}$ For example, Professor John Yoo-relying on historical materials from the ratification period-has recently concluded that "while the national political process may have been the primary safeguard of federalism, it was not the exclusive safeguard of federalism. ${ }^{145}$

existence of the states and their political power to influence the action of the national authority.").

${ }^{140} 469$ U.S. 528 (1985).

141 426 U.S. 833 (1976).

142 Garcia, 469 U.S. at 550-51 (citing Wechsler, supra note 13).

14 Id. at 556.

${ }^{144}$ See, e.g., Jesse H. Choper, Federalism and Judicial Review: An Update, 21 HASTINGS CONST. L.Q. 577, 590-91 (1994) (disagreeing with the theory that the courts should play a more activist role in states' rights issues); Larry Kramer, Understanding Federalism, 47 VAND. L. REV. 1485, 1503 (1994) (stating that the "non-role of courts in federalism" prompts the need to instead focus on the political process); Deborah Jones Merritt, The Guarantee Clause and State Autonomy: Federalism for a Third Century, 88 Colum. L. REV. 1, 78 (1988) (arguing that the Court, in reviewing Guarantee Clause claims, serves as "an impartial umpire to reconcile the competing claims of state and national power"); William W. Van Alstyne, The Second Death of Federalism, 83 MICH. L. REV. 1709, 1722-33 (1985) (suggesting that an examination of Framers' intent and citizen choice supports judicial review of federalism questions); John C. Yoo, The Judicial Safeguards of Federalism, 70 S. CAL. L. REV. (forthcoming July 1997) (manuscript at 2) (arguing that "Garcia is no longer the controlling law theory concerning judicial review of federalism questions") .

${ }^{145}$ Yoo, supra note 144 (manuscript at 82 ). Recent scholarship has also made the case that Professor Wechsler's thesis "seems wildly out of date in the [modern] politi- 
Rather, according to Professor Yoo, "the Framers-both Federalists and Anti-Federalists-understood the text and the structure of the Constitution to permit judicial review in cases questioning the scope of federal power." ${ }^{146}$ Whether the Supreme Court ultimately embraces judicial review of federalism questions, however, is largely immaterial for present purposes. ${ }^{147}$ For this debate concerns only whether the political safeguards of federalism are to be considered the exclusive or merely the primary means of protecting state sovereignty. ${ }^{148}$ In either case, the political safeguards of federalism remain among the Constitution's most important structural mechanisms to check federal power. ${ }^{149}$

Strict adherence to the principles of judicial federalism recognized in Erie is necessary to ensure that the political safeguards of federalism serve their intended function. Although the political safeguards of federalism limit the exercise of federal power by Congress and the President, these safeguards cannot similarly constrain lawmaking by federal courts because "the States are represented in

cal world." Steven G. Calabresi, "A Government of Limited and Enumerated Powers": In Defense of United States v. Lopez, 94 MiCH. L. REv. 752, 792 (1995).

${ }^{146}$ Yoo, supra note 144 (manuscript at 81).

${ }^{147}$ The Court's recent decisions suggest that, notwithstanding Garcia, the Court is prepared to exercise judicial review to police the boundaries of federal power. See, e.g., Printz v. United States, 117 S. Ct. 2365, 2383 (1997) (holding the provision in the Brady Handgun Violence Prevention Act requiring "background checks on prospective handgun purchasers" unconstitutional as a violation of state sovereignty); United States v. Lopez, 514 U.S. 549, 567 (1995) (refusing to "convert congressional authority under the Commerce Clause to a general police power of the sort retained by the States" and invalidating the Gun-Free School Zones Act of 1990); New York v. United States, 505 U.S. 144, 188 (1992) ("Whatever the outer limits of [state] sovereignty may be, one thing is clear: The Federal Government may not compel the States to enact or administer a federal regulatory program."); see also Yoo, supra note 144 (manuscript at 25) ("Whether the Court will explicitly overrule Garcia is almost a moot question, because the Court already has decided to ignore its requirements and to exert full judicial review over questions involving state sovereignty and federalism.").

148 Compare Yoo, supra note 144 (manuscript at 82) (concluding that " $[t]$ he historical evidence... shows an understanding among the leading ratifiers that while the national political process may have been the primary safeguard of federalism, it was not the exclusive safeguard of federalism"), with Wechsler, supra note 13, at 546 (suggesting that the political safeguards of federalism should be treated as exclusive).

${ }_{149}$ See THE FEDERALIST No. 51, at 323 (James Madison) (Clinton Rossiter ed., 1961) (stating that "a double security arises to the rights of the people" because "[i]n the compound republic of America, the power surrendered by the people is first divided between two distinct governments, and then the portion allotted to each subdivided among distinct and separate departments"). 
Congress but not in the federal courts." ${ }^{150}$ Thus, for the political safeguards of federalism to function as an effective check on the exercise of federal power, the federal government-including its courts-must adhere closely to the various constitutional procedures that govern adoption of federal law. All of these procedures require participation by the political branches, and thus any resulting law necessarily has been tempered by the political safeguards of federalism. Open-ended lawmaking by federal courts, on the other hand, is beyond the reach of these procedures, and thus unchecked by the political safeguards of federalism.

From this perspective, Erie correctly concluded that "the doctrine of Swift $v$. Tyson is, as Mr. Justice Holmes said, 'an unconstitutional assumption of powers by the courts of the United States which no lapse of time or respectable array of opinion should make us hesitate to correct."'151 As discussed, the Swift doctrine increasingly permitted federal courts to displace state law and to take it upon themselves "to declare substantive rules of common law applicable in a State."152 Rules so declared and applied effectively permitted the federal government-acting through its courts-to evade both the political and procedural safeguards of federalism. Thus, in retrospect, it is not surprising that Erie found such unchecked lawmaking by federal courts to "invade[] rights... reserved by the Constitution to the several States." 153

Second, Erie's allocation of exclusive federal lawmaking power to the political branches also helps to explain the Supreme Court's subsequent "development of two separate lines of cases" ${ }^{154}$ to determine whether federal courts should apply state or federal law to govern matters that fall "within the uncertain area between substance and procedure." Erie requires federal courts sitting in diversity to apply the substantive law of the state in which they sit, but permits them to apply federal procedural law. As every law student knows, the distinction between substance and procedure is not always immediately apparent. The Supreme Court has developed two distinct ap-

${ }^{150}$ City of Milwaukee v. Illinois, 451 U.S. 304, 317 n.9 (1981); see Mishkin, supra note 118 , at 1685 (noting that "the states, and their interests as such, are represented in the Congress but not in the federal courts").

151304 U.S. at 79 (quoting Black \& White Taxicab \& Transfer Co. v. Brown \& Yellow Taxicab \& Transfer Co., 276 U.S. 518, 533 (1928) (Holmes, J., dissenting)).

${ }^{152}$ Id. at 78; see supra notes $82-87$ and accompanying text.

153304 U.S. at 80.

${ }^{154}$ Hanna v. Plumer, 380 U.S. 460, 471 (1965).

135 Id. at 472. 
proaches for resolving such ambiguities. The first approach applies in the absence of an applicable federal statute or federal rule promulgated pursuant to a federal statute. In such cases, the Court employs tests that encourage federal courts to apply even arguably substantive state law over a contrary federal practice. ${ }^{156}$ For example, the Court has instructed federal courts at various times to make this choice based on several considerations: whether "the outcome of the litigation in the federal court [would] be substantially the same ... as it would be if tried in a State court"; ${ }^{157}$ whether the state rule was "intended to be bound up with the definition of the rights and obligations of the parties"; ${ }^{158}$ and whether application of state law furthers "the twin aims of the Erie rule: discouragement of forum-shopping and avoidance of inequitable administration of the laws." ing to the Supreme Court, if a federal court answers such questions in the affirmative, then the court should apply state law absent extraordinary "affirmative countervailing considerations."160

Significantly, in Hanna v. Plumer, the Supreme Court established a conceptually distinct approach for deciding whether to apply a federal statute or a federal rule promulgated pursuant to a federal statute. ${ }^{161}$ Under this second approach:

If a federal statute covers the point in dispute, [a federal court need only] inquire whether the statute represents a valid exercise of Congress' authority under the Constitution. If Congress intended to reach

${ }^{150}$ See, e.g., Walker v. Armco Steel Corp., 446 U.S. 740, 753 (1980) (applying a state's statute-of-limitation law to an action based on state law being litigated in federal court); Cohen v. Beneficial Indus. Loan Corp., 337 U.S. 541, 557 (1949) (holding that a federal court, in a stockholder's derivative action suit involving diversity of citizenship, must apply a state statute making an unsuccessful plaintiff liable for the reasonable expenses of the defense and allowing the defendant to require indemnity before trial); Woods v. Interstate Realty Co., 337 U.S. 535, 538 (1949) (holding that a state-law requirement preventing a party from pursuing a remedy in a state court also bars recovery in a federal court); Ragan v. Merchants Transfer \& Warehouse Co., 337 U.S. 530, 533-34 (1949) (concluding that where local law creates the right which a federal court, pursuant to diversity jurisdiction, is asked to enforce, the federal court must apply the local statute of limitations); Guaranty Trust Co. v. York, 326 U.S. 99, 109 (1945) (applying a state's statute-of-limitation law to an action based on state law being litigated in federal court).

${ }^{157}$ York, 326 U.S. at 109.

${ }^{158}$ Byrd v. Blue Ridge Rural Elec. Coop., 356 U.S. 525, 536 (1958).

159 Hanna, 380 U.S. at 468.

${ }^{160}$ Byrd, 356 U.S. at 537. To date, the Supreme Court has identified such "countervailing considerations" on only one occasion. See id. at 538 (concluding that, in the circumstances of the case, "the federal policy favoring jury decisions of disputed fact questions should [not] yield to the [contrary] state rule").

${ }^{16 i} 380$ U.S. at 472. 
the issue before the district court, and if it enacted its intention into law in a manner that abides with the Constitution, that is the end of the matter; "[f]ederal courts are bound to apply rules enacted by Congress with respect to matters ... over which it has legislative power." ${ }^{162}$

The Court grants similar deference to federal procedural rules promulgated pursuant to the Rules Enabling Act, ${ }^{163}$ whereby Congress delegated a substantial portion of its rulemaking power to the Court. $^{164}$ So long as the federal rule in question falls within the scope of the Rules Enabling Act, ${ }^{165}$ the only question is whether the rule "regulates matters which can reasonably be classified as procedural, thereby satisfying the constitutional standard for validity."166

The "development of two separate lines of cases" ${ }^{\text {"167 }}$ is consistent with the principles of judicial federalism underlying the Supreme Court's decision in Erie. In the absence of congressional action, a federal court's decision to disregard state law turns on an assessment of whether the rule in question is one of substance or procedure. ${ }^{168}$ If

${ }^{162}$ Stewart Org., Inc. v. Ricoh Corp., 487 U.S. 22, 27 (1988) (second alteration in original) (citation omitted) (quoting Prima Paint Corp. v. Flood \& Conklin Mfg. Co., 388 U.S. 395, 406 (1967)). Congress's power in this regard is quite broad "under Article III as augmented by the Necessary and Proper Clause." Id. at 32. As the Court explained in Hanna:

[T] he constitutional provision for a federal court system ... carries with it congressional power to make rules governing the practice and pleading in those courts, which in turn includes a power to regulate matters which, though falling within the uncertain area between substance and procedure, are rationally capable of classification as either.

380 U.S. at 472.

${ }^{163} 28$ U.S.C. $\$ 2072$ (1994).

${ }^{\text {It }}$ Although the Act authorizes the Supreme Court "to prescribe general rules of practice and procedure," it also provides that "[s] uch rules shall not abridge, enlarge or modify any substantive right." Id. $\$ 2072$ (a)-(b).

165 The precise scope of the Rules Enabling Act is unclear, but Congress apparently has delegated something less than the full measure of its constitutional power to the Supreme Court. See John Hart Ely, The Irrepressible Myth of Erie, 87 Harv. L. Rev. 693, 718-19 (1974) (noting that the Act limits the Court's rulemaking power to matters of practice and procedure that do not abridge substantive rights).

${ }^{166}$ Burlington N. R.R. Co. v. Woods, 480 U.S. 1, 8 (1987).

${ }^{167}$ Hanna, 380 U.S. at 471.

169 Objections based on judicial federalism do not apply to the federal courts' failure to follow state procedural rules. "Certain implied powers must necessarily result to our courts of justice from the nature of their institution." United States v. Hudson, 11 U.S. 21, 23, 7 Cranch 32, 34 (1812). Such implied powers include the authority to adopt rules of practice and procedure, notwithstanding a state's adoption of contrary rules to govern proceedings in state court. See Robinson v. Campbell, 16 U.S. 100, 104-05, 3 Wheat. 211, 222-23 (1818) (rejecting the argument that section 34 of the Judiciary Act of 1789 required federal courts to follow state practice rather than general equity remedies and common-law procedures). 
the rule is deemed to be substantive, then both Erie and subsequent cases favoring application of state law "reflect and restate constitutional principles [of judicial federalism] which restrain the power of the federal courts to intrude upon the states' determination of substantive policy in areas which the Constitution and Congress have left to state competence."

By contrast, when Congress-or the Supreme Court acting pursuant to a permissible congressional delegation-adopts the rule in question, then "the question facing the court is a far cry from the typical, relatively unguided Erie choice. ${ }^{.170}$ In such cases, the central question is whether the rule falls within Congress's constitutional authority, even if the rule governs matters that are arguably (or even clearly) substantive. If the rule falls within Congress's powers, then there can be no objection based on traditional principles of federalism that the federal government has exceeded its delegated authority. In addition, so long as appropriate agents of the federal government adopt the rule in question according to the procedures specified in the Constitution, then the political and procedural safeguards of federalism remain operative, and there can be no objection based on judicial federalism that the federal courts' application of such rules usurps state authority. ${ }^{171}$

\section{Erie and Independent Judgment}

Having identified judicial federalism as the constitutional basis for the Supreme Court's decision in Erie, it is now possible to evaluate the constitutionality of the independent judgment approach suggested by Professor Corbin and employed by the Seventh Circuit in

${ }^{169}$ Mishkin, supra note 118 , at 1688 (emphasis added).

${ }^{170}$ Hanna, 380 U.S. at 471.

${ }^{171}$ See U.S. CONST. art. VI, cl. 2 (stating that " $[t]$ his Constitution, and the Laws of the United States which shall be made in Pursuance thereof . . shall be the supreme Law of the Land"). Congress's delegation of authority to the Supreme Court "to prescribe general rules of practice and procedure," Rules Enabling Act, 28 U.S.C. $\S 2072$ (a) (1994), does not appear to give rise to judicial federalism concerns of the sort that might arise if Congress delegated substantive lawmaking power to federal courts. Compare Wayman v. Southard, 23 U.S. 1, 19, 10 Wheat. 1, 42-43 (1825) (upholding Congress's delegation of rulemaking power to courts because such power is not "strictly and exclusively legislative"), with Postum Cereal Co. v. California Fig Nut Co., 272 U.S. 693, 700 (1927) (stating that Congress may not vest Article III courts "with administrative or legislative functions which are not properly judicial"), and Keller v. Potomac Elec. Power Co., 261 U.S. 428, 444 (1923) (stating that the jurisdiction of Article III courts is limited to deciding cases and controversies and "does not extend to ... administrative or legislative issues or controversies"). 
Daily $v$. Parker. ${ }^{172}$ The principles of judicial federalism underlying Erie apply not only when state common law is clear (as the Supreme Court assumed in Swift), but also when state law is silent or indeterminate. Thus, the Seventh Circuit's decision in Daily to adopt and apply a novel cause of action raises significant judicial federalism concerns. Although it is true that the Daily court did not disregard existing state court precedent (because there was none), the Seventh Circuit nonetheless exercised substantial policymaking discretion on behalf of the state by adopting a novel common-law cause of action not yet recognized by agents of the state. ${ }^{173}$

Not even the most ardent supporters of independent judgment or prediction suggest that the resulting cause of action constitutes state law because, under Erie, only agents of the state have authority to adopt such law. ${ }^{174}$ Accordingly, it is undisputed that state courts at all levels remain free in future cases to exercise their own policymaking discretion and disregard a federal court's recognition of a novel cause of action. Nor is it possible to view the cause of action as a form of federal law-it was not adopted pursuant to the various procedures set forth in the Constitution for the adoption of federal law, and it does not preempt contrary state law. In fact, under Erie, federal courts must abandon such "law" as soon as agents of the state act decisively to reject it. Despite the fact that the cause of action recognized in Daily does not constitute the sovereign command of either the federal government or the states, the rule of decision adopted by the Seventh Circuit governs at least the rights and duties of the parties to the case, ${ }^{175}$ and perhaps will control those of others who litigate their cases (voluntarily or involuntarily) in federal court. ${ }^{176}$

At least with respect to the parties before the court, federal courts employing independent judgment appear to be exercising the "power to declare substantive rules of common law applicable in a State,"177 contrary both to Erie's express prohibition and to the principles of

${ }^{172} 152$ F.2d 174 (7th Cir. 1945).

${ }^{173}$ See supra text accompanying notes 75-81.

${ }^{174}$ See Erie, 304 U.S. at 79 ("'[T] that be so, the voice adopted by the State as its own [whether it be of its Legislature or of its Supreme Court] should utter the last word." (second alteration in original) (quoting Black \& White Taxicab \& Transfer Co. v. Brown \& Yellow Taxicab \& Transfer Co., 276 U.S. 518, 535 (1928) (Holmes, J., dissenting))).

${ }^{173}$ See infra notes $231-34$ and accompanying text.

176 See infra notes $440-41$ and accompanying text (explaining how both the predictive and static approaches often lead to forum shopping).

17 Erie, 304 U.S. at 78. 
judicial federalism underlying the decision. From this perspective, there appears to be no a priori reason why a federal court's usurpation of dormant state lawmaking power is any less offensive to the constitutional structure than a federal court's decision during the Swift era to disregard preexisting law of the state as declared by its courts. In either case, a federal court's practice of "indulg[ing] in lawmaking by decisions" ${ }^{\prime 178}$ necessarily interferes with the sovereign prerogative of the states to decide both whether and how to regulate the conduct of the parties. As Erie recognized, agents of the federal government may displace this prerogative only by adopting positive federal law that complies both with the Constitution's limited delegation of authority to the federal government and with the specific constitutional procedures designed to check federal power and implement the political safeguards of federalism.

\section{THE PREDICTIVE APPROACH}

Perhaps because of these structural concerns, federal courts have largely abandoned any claim that they are entitled to use independent judgment to generate rules of decision on behalf of the states. Rather, when existing sources of state law do not yield a determinate answer to a particular legal question, most federal courts today employ a predictive approach-that is, they attempt to forecast how the state's highest court would decide the question were the case before it. ${ }^{179}$ This Part traces the origin and development of the federal courts' current practice of predicting the course of state law, and critically examines several examples of the practice. This Part concludes that, like independent judgment, the predictive model raises judicial federalism concerns because it permits federal courts to exercise lawmaking power on behalf of the states-both by weighing competing policy considerations and by fashioning "substantive rules

${ }^{178}$ Daily v. Parker, 152 F.2d 174, 177 (7th Cir. 1945).

${ }^{179}$ See, e.g., Travelers Ins. Co. v. 633 Third Assocs., 14 F.3d 114, 119 (2d Cir. 1994) (stating that " $[w]$ here the substantive law of the forum state is uncertain or ambiguous, the job of the federal courts is carefully to predict how the highest court of the forum state would resolve the uncertainty or ambiguity"); Clark v. Modern Group Ltd., 9 F.3d 321, 326 (3d Cir. 1993) ("When the application of [the law of the forum] is not clear ... we must forecast the position the supreme court of the forum would take on the issue."); Belline v. K-Mart Corp., 940 F.2d 184, 186 (7th Cir. 1991) (recognizing that federal courts in diversity cases "must strive to parse state law and, if necessary, forecast its path of evolution"). See generally 19 CHARLES ALAN WRIGHT ET AL., FEDERAL PRACTICE AND PROCEDURE $\S 4507$ (2d ed. 1996) (detailing the federal court's use of the predictive approach). 
of common law applicable in a State ${ }^{\text {n180 }}$-without regard to the political and procedural safeguards of federalism established by the Constitution.

Although the Supreme Court has never squarely endorsed the predictive approach, several of the Court's post-Erie opinions appear to suggest that this model is preferable to independent judgment. Erie itself is unclear on this point. The Court's opinion refers only to "the law of the State" as declared "by its highest court in a decision." 181 As discussed, following Erie, some lower federal courts took this reference to mean that, in the absence of a decision by the state's highest court, federal courts were free to exercise independent judgmentthat is, to disregard decisions by lower state courts and "to adopt and apply what [they] considered to be the better rule. ${ }^{182}$

The Supreme Court issued a series of decisions just two years after Erie to put an end to this practice and, in so doing, may have inadvertently sowed the seeds of the predictive approach. ${ }^{183}$ For example, as the Court stated in West $v$. ATE T Co., a "rule of law" announced by an intermediate appellate state court "is not to be disregarded by a federal court unless it is convinced by other persuasive data that the highest court of the state would decide otherwise. ${ }^{184}$ Three years later, in Meredith $v$. Winter Haven, the Court suggested that federal courts confronted with other sources of indeterminacy follow essentially the same course. ${ }^{185}$ Meredith presented the federal courts

${ }^{180}$ Erie, 304 U.S. at 78.

${ }^{181}$ Id.

${ }^{182}$ West v. AT\&T Co., 311 U.S. 223, 235 (1940); see also, e.g., New York Life Ins. Co. v. Stoner, 109 F.2d 874, 878 (8th Cir.) (stating that "[w]e are not bound to follow the decisions and reasoning of the intermediate appellate courts of Missouri"), rev'd, 311 U.S. 464 (1940); Missouri v. A.B. Collins \& Co., 34 F. Supp. 550, 553 (W.D. Mo. 1940) (stating that "[o]f course the decision of an intermediate appellate court in Missouri is not binding upon this court").

${ }^{183}$ See West, 311 U.S. 223,237 (stating that ${ }^{~}[\mathrm{w}]$ here an intermediate appellate state court rests its considered judgment upon the rule of law which it announces, that is a datum for ascertaining state law which is not to be disregarded by a federal court"); Six Cos. v. Joint Highway Dist. No. 13, 311 U.S. 180, 188 (1940) (applying "an announcement of the state law by a intermediate appellate court [where] there is no convincing evidence that the law of the state is otherwise"); Fidelity Union Trust Co. v. Field, 311 U.S. 169, 177 (1940) (stating that "it is . . the duty of the federal courts . . to ascertain and apply that [state] law even though it has not been expounded by the highest court of the State").

${ }^{184} 311$ U.S. at 237 (emphasis added).

${ }^{185} 320$ U.S. 228, 234-35 (1943) (suggesting that federal courts cannot refuse to exercise jurisdiction merely because the question of state law is "difficult or uncertain"). 
with two questions of state law. The first had recently been resolved by the Florida Supreme Court, but one of the parties argued that the Florida Supreme Court might not adhere to this resolution. ${ }^{186}$ The Supreme Court again appeared to suggest a predictive approach: "[T] he rulings of the Supreme Court of Florida ... must be taken as controlling here unless it can be said with some assurance that the Florida Supreme Court will not follow them in the future. ${ }^{\text {187 }}$ The second question raised in Meredith was, as the Court put it, one that "ha[d] not been passed upon by the Florida courts." 188 Even with respect to such questions of first impression, the Court spoke in terms of prediction. According to the Court, "the difficulties of ascertaining what the state courts may hereafter determine the state law to be do not in themselves afford a sufficient ground for a federal court to decline to exercise its jurisdiction to decide a case which is properly brought to it for decision." ${ }^{189}$

Unlike interpretation of state law, the predictive approach suggested in these opinions is distinctively forward-looking. When federal courts attempt merely to interpret and apply state law, they look to preexisting sources of state law in order to ascertain the precise content of such law. A successful attempt yields what courts consider to be rules of decision that have already been adopted by appropriate agents of the state. Prediction, by contrast, attempts to forecast the development of state law by asking what rule of decision the state's highest court is likely to adopt in the future. Undoubtedly, courts and commentators may disagree over the precise point at which interpretation ends and prediction begins. ${ }^{190}$ Whether one characterizes a particular rule of decision as the result of prediction or interpretation, for example, may turn on whether one takes a broad or narrow approach to interpretation. Whichever approach one employs, however, legal indeterminacy, at some point, prevents courts from ascertaining state law through interpretation and thus necessitates use of some alternative approach.

Most lower federal courts employ a predictive approach when faced with indeterminate state law. For example, as early as 1944, the

${ }^{186}$ See id. at 233 ("It is the contention of the petitioners that the Andrews case is not controlling because it ... is inconsistent with earlier decisions of the Supreme Court of Florida .....").

${ }^{187} I d$. at 234 (emphasis added).

${ }^{183}$ Id. at 232.

${ }^{189} I d$. at 234 (emphasis added).

190 See supra notes 43-52 and accompanying text. 
Third Circuit described the proper method of deciding unsettled questions of state law in terms of prediction:

In order to apply local law where there is no authoritative local decision or statute, it is incumbent upon a federal court to ascertain and apply what it believes to be the law which a court, authorized to speak the law of the particular State, would apply if called upon to adjudicate upon like circumstances. ${ }^{191}$

The same court expanded upon this approach thirty-six years later in what has become one of the most widely cited opinions on federal court prediction of state law. According to the court, "a federal court attempting to forecast state law must consider... [all] reliable data tending convincingly to show how the highest court in the state would decide the issue at hand." ${ }^{192}$ Thus, although dissenting on other grounds, Chief Justice Rehnquist observed in 1991, without contradiction by the Court, that in cases "where the state law is unsettled ... the [federal] courts' task is to try to predict how the highest court of that State would decide the question."

Notwithstanding the lower federal courts' general embrace of the predictive approach, this model raises substantial constitutional concerns under the principles of judicial federalism recognized in Erie. On the surface, the predictive approach may appear to threaten federalism less than a federal court's exercise of independent judgment because prediction expressly attempts to divine, and thus give effect to, the state's likely policy preferences. ${ }^{194}$ As the Supreme Court itself has recognized, however, "no matter how seasoned the judgment of the district court may be, it cannot escape being a forecast

${ }^{191}$ Jackman v. Equitable Life Assurance Soc'y, 145 F.2d 945, 947 (3d Cir. 1944) (citing Meredith, 320 U.S. at 234).

${ }_{192}$ McKenna v. Ortho Pharm. Corp., 622 F.2d 657, 663 (3d Cir. 1980). However, even among courts following the predictive approach, "[i]t is unclear which pieces of jurisprudential evidence the court must consider, or which are most probative." Jed I. Bergman, Note, Putting Precedent in Its Place: Stare Decisis and Federal Predictions of State Law, 96 COLUM. L. REV. 969, 976 (1996).

${ }^{193}$ Salve Regina College v. Russell, 499 U.S. 225, 241 (1991) (Rehnquist, C.J., dissenting). For a useful discussion of the origins of the predictive approach in diversity cases, see Michael C. Dorf, Prediction and the Rule of Lau, 42 UCLA L. REV. 651, 696-701 (1995).

${ }^{194}$ Dolores K. Sloviter, A Federal Judge Views Diversity Jurisdiction Through the Lens of Federalism, 78 VA. L. REv. 1671, 1682 (1992) (stating that " $[t]$ he incursion of federal judges into what are often policy decisions is subtle and, because it is denominated 'prediction of state law' rather than 'state lawmaking,' it has been far less dramatic and controversial" than other practices that raise federalism concerns). 
rather than a determination., ${ }^{195}$ Indeed, by hypothesis, prediction occurs only when determination of state law is not possible. This means that federal courts employing a predictive approach cannot merely apply the pre-existing "law of the State" as declared by its legislature and its courts. Rather, federal courts frequently consult such diverse materials as state trial court decisions, unreported decisions, dictum, "considered dictum," state attorney general opinions, state agency constructions, public policy, decisions from other jurisdictions, the majority rule, restatements, treatises, and law review articles. ${ }^{196}$

Because state law generally fails to provide meaningful guidance regarding what weight, if any, to give such materials, ${ }^{197}$ a federal court's "prediction" of state law frequently devolves into little more than a choice among competing policy considerations. No matter how pure a federal court's intentions may be, legal indeterminacy necessarily requires courts to exercise some degree of policymaking discretion. $^{198}$ Some lower federal courts have openly acknowledged this correlation. For example, in 1980, the Sixth Circuit was called upon to decide, as a matter of Tennessee law, whether Elvis Presley's right of publicity survived his death. ${ }^{199}$ At the outset of its opinion, the Sixth Circuit candidly described its task as follows:

Tennessee courts have not addressed this issue directly or indirectly, and we have no way to assess their predisposition. Since the case is one

195 Railroad Comm'n v. Pullman Co., 312 U.S. 496, 499 (1941).

196 See WRIGHT ET AL., supra note $179, \S 4507$, at 141-69, 190-200 (discussing the sources to be relied on by federal courts in determining state law); see also CHEMERINSKY, supra note $91, \$ 5.3$, at 310 (stating that "federal court[s] may consider all available material in deciding what law would be followed by a state").

${ }^{197}$ On occasion, states adopt a background rule of state law that incorporates another source of law by reference. See, e.g., Gray v. American Express Co., 743 F.2d 10, 17 (D.C. Cir. 1984) (noting that when District of Columbia law is silent, courts sitting in the District of Columbia look to Maryland law to resolve unsettled questions of law); Passwaters v. General Motors Corp., 454 F.2d 1270, 1277-78 (8th Cir. 1972) (observing that Iowa courts follow the decisions of the courts relied upon by the Iowa Supreme Court when it first adopted strict liability rules to resolve novel questions); Yost v. Morrow, 262 F.2d 826, 828 n.3 (9th Cir. 1959) (stating that Idaho follows the choice-of-law decisions of the Oregon Supreme Court in the absence of controlling precedent). Background rules of this sort go far to alleviate the judicial federalism concerns raised by federal court predictions of state law in the absence of such rules.

${ }^{198}$ See Sloviter, supra note 194, at 1682 (stating that "[ $t$ ] he federal judge's prediction of state law in the absence of a dispositive holding of the state supreme court often verges on the lawmaking function of that state court"); supra notes 43-52 and accompanying text.

${ }^{199}$ Memphis Dev. Found. v. Factors Etc., Inc., 616 F.2d 956 (6th Cir. 1980). 
of first impression, we are left to review the question in the light of practical and policy considerations, the treatment of other similar rights in our legal system, the relative weight of the conflicting interests of the parties, and certain moral presuppositions concerning death, privacy, inheritability and economic opportunity. ${ }^{200}$

On the basis of these considerations, the Sixth Circuit decided that an individual's right of publicity does not survive death under Tennessee law. ${ }^{201}$

Given the range of opinion on matters of this kind, it is not surprising that federal courts often fail to forecast the development of state law accurately. ${ }^{202}$ From a constitutional standpoint, however, whether predictions like this one ultimately turn out to be correct is less significant than the nature of the court's undertaking. The exercise of substantial policymaking discretion is the essence of lawmaking. The exercise of such discretion by state courts "is not a matter of federal concern" because the Constitution imposes few, if any, restrictions on judicial lawmaking at the state level. ${ }^{203}$ The exercise of substantial policymaking discretion by federal courts, however, raises serious judicial federalism concerns. As Judge Sloviter has observed, ${ }^{2}[w]$ hen federal judges make state law-and we do, by whatever euphemism one chooses to call it-judges who are not selected under the state's system and who are not answerable to its constituency are undertaking an inherent state court function." ${ }^{204}$ Even assuming that the federal government has constitutional power to regulate the matters at issue in the case, allowing federal courts to weigh-and to choose among-competing policy considerations under the guise of prediction permits the federal government to evade the procedural and political safeguards established by the Constitution to check the exercise of such power. As discussed, the Constitution not only limits the powers available to the federal government, but also restricts the manner in which that government may exercise them-both by generally distributing governmental powers among three distinct

Id. at 958 .

201 See id. at 960.

${ }^{202}$ See Sloviter, supra note 194, at 1679 (recounting that "[d] espite our best efforts to predict the future thinking of the state supreme courts within our jurisdiction on the basis of all of the available data, [federal judges in the Third Circuit] have guessed wrong" in a "not insignificant number" of cases).

${ }^{203}$ Erie, 304 U.S. at 78; see supra notes 53-57 and accompanying text (noting that state judicial lawmaking is limited only by the Constitution's requirement that each state maintain "a Republican Form of Government").

${ }^{204}$ Sloviter, supra note 194, at 1687. 
branches and by establishing specific procedures to govern the adoption of federal law. ${ }^{205}$

Thus, at least in practice, the predictive approach runs counter to Erie's observation that "no clause in the Constitution purports to confer ... power upon the federal courts" to adopt "substantive rules of common law applicable in a State. ${ }^{206}$ When the political branches of the federal government exercise their constitutional authority to adopt substantive rules of law applicable in the states, the states' interests are protected by the Constitution's various procedural and political safeguards. ${ }^{207}$ This is true even though a state has not adopted, and may never adopt, the substantive rule in question as a matter of state law. By contrast, when federal courts fashion substantive rules of common law applicable in a state using the predictive approach, both the procedural and political mechanisms established by the Constitution to check the exercise of federal power are absent. For this reason, such lawmaking by federal courts-no less than independent judgment or general common lawmaking under Swift"invade[s] rights... reserved by the Constitution to the several States, ${ }^{208}$ especially the right of states to decide for themselves both whether and when to adopt the rule in question in the absence of controlling federal law. ${ }^{209}$

Three cases discussed below illustrate the various contexts in which these judicial federalism concerns may arise. The first case examines a federal court's use of the predictive model to recognize a novel cause of action on behalf of a state. The second case concerns a federal court's adoption of a novel defense. Finally, the third case explores the federalism implications of a federal court's prediction that the state's highest court is prepared to overrule a precedent. In each of these contexts, prediction raises serious constitutional concerns by permitting federal courts to adopt and apply "substantive

${ }^{205}$ See supra notes $117-32$ and accompanying text.

${ }^{206}$ Erie, 304 U.S. at 78.

207 See supra notes 14, 125-27, 138-43 and accompanying text.

${ }^{203}$ Erie, 304 U.S. at 80; $c$. Sloviter, supra note 194, at 1682 (explaining that "[t]he incursion of federal judges into what are often policy decisions," although "denominated "prediction of state law," "involves areas of law that define one citizen's rights and obligations vis-a-vis another's, a function traditionally associated with state sovereignty and therefore with state courts").

${ }_{209}$ See Sloviter, supra note 194, at 1671 (arguing that diversity jurisdiction "results in the inevitable erosion of the state courts' sovereign right and duty to develop state law as they deem appropriate"). 
rules of common law applicable in a State" before the state itself has made such rules part of its law. ${ }^{210}$

\section{A. Prediction of a Novel Cause of Action}

Bulloch $v$. United States, ${ }^{211}$ a case involving federal incorporation of state law, illustrates the potential constitutional difficulties raised by a federal court's use of the predictive approach to recognize a novel state-law cause of action. ${ }^{212}$ In Bulloch, unmarried cohabitants sued the United States for loss of consortium in federal district court pursuant to the Federal Tort Claims Act, which permits plaintiffs to recover damages "under circumstances where the United States, if a private person, would be liable to the claimant in accordance with the law of the place where the act or omission occurred."213 The defendant moved to dismiss on the ground that the plaintiffs were not legally married and therefore that they were "not entitled to compensation for loss of any consortium." ${ }^{\text {214 }}$ The plaintiffs responded that marriage is not a prerequisite to an action for loss of consortium under New Jersey law. Because this case appeared to be the first in which a plaintiff "argued that a legal marriage need not be shown to prevail on a consortium claim, "215 the district court characterized the case as one "of first impression,"

${ }^{210}$ Professor Caminker has recently suggested that "[ $\left.t\right]$ he proxy model's halfcentury pedigree in the Erie doctrine lends at least nontrivial, and I think significant, credibility to the claim that prediction, carefully performed, is a coherent and workable approach to judicial decisionmaking" generally. Evan H. Caminker, Precedent and Prediction: The Forward-Looking Aspects of Inferior Court Decisionmaking, 73 TEX. L. REV. 1, 74 (1994). Under the approach he suggests, "an inferior court [would] not simply ... interpret the law in light of superior court precedents, but rather [would] act as a proxy for its superior court by 'attempt[ing] to replicate the result that would be reached if the [superior court] were faced with the same set of facts and allegations."' Id. at 5 (third and fourth alterations in original) (quoting Earl M. Maltz, The Concept of the Doctrine of the Court in Constitutional Law, 16 GA. L. REV. 357, 399 (1982)). Professor Dorf disagrees with this proposal to extend the predictive approach beyond the Erie context on the ground that "[a]n expressly prediction-based model would undermine the ideal of impersonal justice by merging law and politics." Dorf, supra note 193, at 688.

211487 F. Supp. 1078 (D.N.J. 1980).

${ }^{212}$ Bulloch might also be characterized as involving a novel extension of an existing state-law cause of action in favor of parties not traditionally within the contemplation of the law. See infra notes $237-38$ and accompanying text.

${ }_{213} 28$ U.S.C. $\$ 1346$ (b) (1994); see Bulloch, 487 F. Supp. at 1079.

${ }^{214}$ Bulloch, 487 F. Supp. at 1079.

215 Id. at 1079-80.

${ }^{216} I d$. at 1080 . 
presented [as] a novel one." ${ }^{217}$ The court was of the view that, under these circumstances, its "disposition of this case must be governed by a prediction of what a New Jersey court would do if confronted with the facts before us." 218

In making this prediction, the district court ultimately viewed its task as one of weighing competing policy considerations. Specifically, the court regarded the question to be decided as "whether the policy in favor of marriage in New Jersey is strong enough" to outweigh New Jersey's competing policy of "expanding tort liability to justly compensate those who are injured." ${ }^{219}$ After reviewing various cases and weighing the competing policies, the court "conclude[d] that the New Jersey courts would permit a cohabitant who has suffered the same types of injuries as a spouse to bring an action for loss of consortium. ${ }^{220}$ Accordingly, the district court denied the defendant's motion and permitted the case to proceed to trial.

Two years later, two New Jersey, decisions specifically considered and rejected the contention that unmarried cohabitants may recover for loss of consortium. The first case expressly criticized the district court's holding in Bulloch and characterized the court's analysis as "flaw[ed]." ${ }^{221}$ As a practical matter, the court considered marriage to be "the only dependable means by which a relationship-of which consortium is an element-may be legally defined. ${ }^{222}$ More fundamentally, the court thought that the decision whether to assume the privileges and obligations of marriage should be left to the individuals involved. ${ }^{223}$ The second case also rejected Bulloch's holding, although without mentioning the case by name. According to the court: "The right of recovery for loss of consortium resulting to a wife by reason of an injury to her husband, is founded upon the marriage relation.

${ }^{217}$ Id. at 1079.

${ }^{218}$ Id. at 1082 (quoting Becker v. Interstate Properties, 569 F.2d 1203, 1205 (3d Cir. 1977)).

${ }^{219}$ Id. at 1085 .

220 Id. at 1087.

${ }^{221}$ Childers v. Shannon, 444 A.2d 1141, 1142 (N.J. Super. Ct. Law Div. 1982).

222 Id.

${ }^{223}$ See id. at 1143 ("Presumably, when partners wish social and legal recognition of their relationship, they marry. To accord consortium to an unmarried plaintiff is to force upon him or her a status which he or she had not, at the time of the injury, asserted; it is an ill-conceived intrusion into the private lives of individuals."). 
Absent such relationship, the right does not exist, and thus no recovery may be had for loss thereof."224

In a case like Bulloch, a federal court's erroneous prediction that the state's highest court would recognize a cause of action for loss of consortium on behalf of unmarried cohabitants raises serious judicial federalism concerns. When a state court rejects a novel cause of action previously predicted by a federal court, it becomes clear that the rights and obligations of the parties to the federal court action were determined, not according to "the law of the State," but according to "law" adopted by a federal court. In the Anglo-American legal system, regulation of human affairs through law is the exception rather than the rule. ${ }^{225}$ Thus, generally speaking, "[a]11 things are permitted unless there is some contrary rule. ${ }^{226}$ As Judge Easterbrook has explained: "Those who wrote and approved the Constitution thought that most social relations would be governed by private agreements, customs, and understandings, not resolved in the halls of government. There is still at least a presumption that people's arrangements prevail unless expressly displaced by legal doctrine."227 This presumption in favor of the status quo or private ordering means that even a married person has no a priori right to recover damages for loss of consortium from one who negligently injures his spouse. This right exists solely by virtue of the fact that the relevant stateacting through its legislature or its courts-has adopted a cause of action for loss of consortium in favor of the injured party's spouse.

Given this background presumption, whether an unmarried cohabitant can recover damages from a third party for loss of consortium turns entirely on whether the relevant state recognizes such a claim. In cases like Bulloch-where the question is one of first impression-the state, by definition, has not yet adopted a cause of action that rebuts the presumption of private ordering. However one may characterize the "law" applied by federal courts in cases like Bulloch, it is not state law. ${ }^{228}$ For this reason, the federal courts' application of

${ }^{24}$ Leonardis v. Morton Chem. Co., 445 A.2d 45, 45 (N.J. Super. Ct. App. Div. 1982).

${ }_{225}$ See Frank H. Easterbrook, Statutes' Domains, 50 U. CHI. L. REV. 533, 549 (1983); see also supra notes 34-36 and accompanying text (observing that "the law simply does not apply, by its terms, to a wide variety of human conduct").

${ }_{226}$ Easterbrook, supra note 225, at 549-50.

${ }^{227}$ Id. (footnote omitted).

${ }^{223}$ A potential objection to this conclusion is that it rests on a positivist view of state law-that is, state law consists exclusively of sovereign commands issued by appropriate agents of the state on its behalf. Even if a state explicitly purported to 
such law appears to violate Erie's command that, absent positive federal law, "the law to be applied in any case is the law of the State." This violation triggers judicial federalism concerns because the "law" that federal courts apply in such cases has not been adopted pursuant to the various constitutional procedures, such as bicameralism and presentment, which safeguard federalism. ${ }^{230}$

Even "correct" Erie predictions raise judicial federalism concerns. $^{231}$ As a practical matter, of course, it is impossible for federal courts to know in advance whether their predictions will prove accurate. More fundamentally, however, even if the rule in question is embraced by the state's highest court at a later date, it remains true that the rule applied in federal court did not in fact constitute a sovereign command of the state at the time the federal court rendered its decision. As Professor LeBel has explained:

Insofar as controlling state precedents were concerned, the federal court was writing on a clean slate. The state courts were writing on different slates at different times. That later writing may establish what state law is at the later date, but the state court decisions cannot "relate back" to establish what the state law was at the time the federal court

embrace natural law, however, this circumstance would not empower a federal court to decide cases within its diversity jurisdiction according to its own conception of natural law. Rather, as discussed previously, Erie requires federal courts to ascertain state law on the positivist assumption that "law in the sense in which courts speak of it today does not exist without some definite authority behind it." Erie, 304 U.S. at 79 (quoting Black \& White Taxicab \& Transfer Co. v. Brown \& Yellow Taxicab \& Transfer Co., 276 U.S. 518, 533-34 (1928) (Holmes, J., dissenting)). Whether this assumption is in fact shared by a given state is largely beside the point. The Court's approach rests not on an attempt to identify the actual jurisprudential assumptions of any particular state, but on an assessment of the limited institutional competence of federal courts under the constitutional structure. As discussed, various features of the constitutional structure suggest that federal courts should employ a positivist view of state law in order to implement judicial federalism and avoid usurping the lawmaking authority of the states. See supra notes $116-36$ and accompanying text.

229304 U.S. at 78.

230 See supra notes $14,125-27$ and accompanying text.

${ }^{231}$ For example, the Seventh Circuit's decision in Daily v. Parker, 152 F.2d 174 (7th Cir. 1945)-recognizing a novel state law cause of action for damages by "children, living in Pennsylvania ... against a woman living in Illinois who caused their father to leave them, their mother, and their home and go to Chicago and live with her and to refuse to further contribute to their maintenance and support," id. at 175-raises the judicial federalism concerns discussed in the text, even though Illinois courts subsequently adopted such a cause of action as a matter of state law, see Johnson v. Luhman, 71 N.E.2d 810 (Ill. App. Ct. 1947) (recognizing a novel state-law cause of action and adopting the Seventh Circuit's reasoning). Daily is discussed supra notes 75-81 and accompanying text. 
predicted what the state courts would have done had the issue been before the state courts at that time.

In light of the principles of judicial federalism embraced by the Supreme Court in Erie, it is difficult to avoid the conclusion that federal courts in cases like Bulloch take it upon themselves to exercise substantial policymaking discretion to adopt a "substantive rule[] of common law applicable in a State ${ }^{, 233}$ before the state itself has acted to adopt the rule in question. In this sense, the rights and obligations of the parties in such cases are determined not by the law of the state, but by "law" adopted by a federal court unchecked by the procedural and political safeguards of federalism specified in the Constitution. ${ }^{234}$

It is true, under the predictive approach, that federal courts generally apply the rules they predict only so long as the state itself fails to reject them. Following the New Jersey courts' contrary resolution of the consortium claim at issue in Bulloch, for example, federal courts applying New Jersey law must adhere to the state courts' resolution in deciding future cases (absent a further prediction that New Jersey courts would abandon the marriage requirement). ${ }^{235}$ This feature of the predictive approach arguably makes its use by federal courts less problematic than the application of general common law under Swift, ${ }^{236}$ but it cannot eliminate judicial federalism concerns. Even under the predictive approach, it remains true that all parties to federal actions adjudicated before the state judiciary resolves the issue

${ }^{232}$ LeBel, supra note 37, at 1029.

${ }^{233}$ Erie, 304 U.S. at 78.

${ }^{234}$ Cf. LeBel, supra note 37, at 1015 ("When a federal court makes an Erie determination of a question of first impression, the 'law of the state' that the federal court purports to apply to the case is, in reality, federal law."). It might be argued that federal court prediction of state law is less problematic when the state's highest court acts within a relatively short period of time to embrace the prediction. Such an embrace might be considered evidence that the law of the state was, in fact, what the federal court predicted. If that were true, however, the federal court could have merely determined, rather than predicted, state law. By definition, prediction occurs only when existing state law is indeterminate. If such indeterminacy is to be resolved, agents of the state must undertake a significant degree of policymaking on behalf of the state. See supra notes 43-57 and accompanying text. Whether such policymaking occurs sooner or later after a federal court's prediction does not change the nature of the undertaking.

${ }^{235}$ See infra notes 283-88 and accompanying text (discussing federal court predictions that state precedents will be overruled by state courts).

${ }^{2 * 6}$ Under the Swift doctrine, of course, federal courts continued to apply their own conceptions of general law even after the state's highest court reached a contrary conclusion on the question at issue. See Erie, 304 U.S. at 75-76 (describing the effects of the federal courts' practice under the Swift doctrine). 
will have their rights and obligations determined not according to the law of the state, but according to law adopted by federal courts unconstrained by the various mechanisms set forth in the Constitution to check the exercise of lawmaking power by agents of the federal government.

The preceding discussion assumes that Bulloch adopted a novel cause of action. The judicial federalism concerns identified above, however, apply with equal force whether the federal court's prediction in a case like Bulloch is characterized as the adoption of a novel cause of action or is said merely to call for the extension of an existing cause of action. If the cause of action permitting recovery for loss of consortium applies only when the plaintiff and the injured party are married, then the Bulloch court effectively created a new cause of action in favor of unmarried cohabitants. On the other hand, Bulloch might be characterized as an instance of extending a cause of action to cover a case not clearly contemplated by existing law. Bulloch itself suggests this interpretation. In contrasting Bulloch to a case that "consider[ed] the creation of a new cause of action," the district court remarked that. "the present case only presents the question of whether a cohabiting person qualifies as a plaintiff in an already existing cause of action."237 The "already existing cause of action" is the right that married individuals possess to sue third parties for loss of consortium. As applied to unmarried cohabitants, existing law may have been indeterminate because it arguably, but not clearly, conferred upon such individuals a right to sue. ${ }^{238}$

Whether the Bulloch court created a novel cause of action or merely extended an existing, but indeterminate, one is largely immaterial to the analysis. In either case, the federal court exercised substantial policymaking discretion by recognizing a cause of action in favor of a plaintiff who had no clearly established legal right to recover under state law. If the court created a novel cause of action, then it exercised "the sovereign prerogative of choice" to alter the background presumption of private ordering under state law. Even if the court merely extended an ambiguous cause of action to novel circumstances, however, the court nonetheless performed a significant lawmaking function. As Bulloch well illustrates, the question

${ }^{287}$ Bulloch v. United States, 487 F. Supp. 1078, 1087 (D.N.J. 1980).

${ }^{293}$ The district court should have considered the cause of action at issue in Bulloch to be determinate as applied to the facts of that case if the cause of action either clearly encompassed, or clearly excluded, suit by an unmarried cohabitant for loss of consortium. See supra notes $33-38$ and accompanying text. 
whether to render an ambiguous cause of action determinate by extending it to novel circumstances often requires courts to choose among competing policy considerations-in this case, "the policy in favor of marriage" and the policy "of expanding tort liability." ${ }^{, 239}$ It "is not a matter of federal concern" ${ }^{240}$ when a state court extends a cause of action by weighing such policy considerations, because such courts are entitled "to exercise the sovereign prerogative of choice" on behalf of the states. ${ }^{241}$ According to Erie, however, federal courts possess no such lawmaking power. To the contrary, as Erie held, any attempt by federal courts "to declare substantive rules of common law applicable in a State" ${ }^{\text {"242 }}$ constitutes "'an unconstitutional assumption of powers by courts of the United States." "243

\section{B. Prediction of a Novel Defense}

Although there may be a background presumption that "[a]ll things are permitted unless there is some contrary rule," ${ }^{244}$ once a state adopts a "contrary rule" that clearly establishes particular legal rights and obligations, the presumption is then reversed within the contemplation of the rule. This means that recognition of an exception to liability under an existing rule-through recognition of a novel defense, for example-will itself often entail the exercise of substantial policymaking discretion. To this extent, a federal court's recognition of a novel defense to an existing state-law cause of action-no less than adoption of a novel cause of action-constitutes adoption of a "substantive rule[] of common law applicable in a State, ${ }^{245}$ and thus gives rise to judicial federalism concerns analogous to those discussed above.

DeWeerth v. Baldinger ${ }^{246}$ provides an example. DeWeerth, a citizen of Germany, sued Baldinger, a citizen of New York, in federal court, seeking to recover a stolen painting, Champs de Blé à Vétheuil, by Claude Monet. DeWeerth inherited the painting from her father, who originally purchased it in 1908. During World War II, DeWeerth

${ }^{239}$ Bulloch, 487 F. Supp. at 1085.

${ }^{240}$ Erie, 304 U.S. at 78.

241 Holmes, supra note 49 , at 461 .

242304 U.S. at 78.

${ }^{243}$ Id. at 79 (quoting Black \& White Taxicab \& Transfer Co. v. Brown \& Yellow Taxicab \& Transfer Co., 276 U.S. 518, 533 (1928) (Holmes, J., dissenting)).

${ }^{244}$ Easterbrook, supra note 225, at 549-50.

${ }^{245}$ Erie, 304 U.S. at 78.

${ }^{246} 658$ F. Supp. 688 (S.D.N.Y.), rev'd, 836 F.2d 103 (2d Cir. 1987). 
sent the painting to her sister's home for safekeeping, but the painting disappeared while American troops were quartered there after the war. By 1956, the painting had made its way to the United States through Switzerland, and Baldinger purchased the work in good faith from a reputable New York art gallery in 1957. In 1981, DeWeerth's nephew uncovered a catalogue indicating that the painting had been exhibited at the art gallery in 1970. DeWeerth retained counsel in New York in 1982, discovered that Baldinger had purchased the Monet, and demanded the return of the painting. When Baldinger refused, DeWeerth filed suit to recover the painting. ${ }^{247}$

Established principles of New York law require owners of stolen property to demand return of their property from the party in possession and to file suit within three years if the party refuses the demand. ${ }^{248}$ Although DeWeerth filed her claim within the applicable three-year limitations period following Baldinger's refusal to return the painting, Baldinger defended, inter alia, on the ground that DeWeerth's claim nonetheless should be considered untimely because DeWeerth failed to exercise due diligence to discover the whereabouts of the painting before $1982 .{ }^{249}$ The district court assumed, without deciding, that such a requirement existed under New York law, found that DeWeerth had in fact exercised due diligence, and ordered Baldinger to return the painting to DeWeerth. ${ }^{250}$

The Second Circuit reversed. Acknowledging that the case presented an "unresolved state law issue," employed the predictive approach: "When presented with an absence of controlling state authority, we must 'make an estimate of what the state's highest court would rule to be its law." ${ }^{252}$ After weighing various policy considerations-including prevention of "unnecessary hardship to the good-faith purchaser ${ }^{253}$ of stolen art-and noting a recent decision by the New Jersey Supreme Court imposing a duty of reasonable investigation, the Second Circuit estimated "that the New

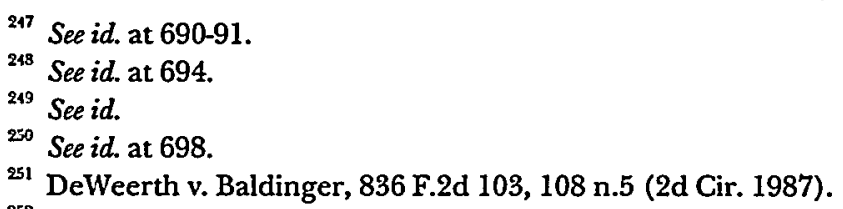

${ }_{252}$ Id. at 108 (quoting Stafford v. International Harvester Co., 668 F.2d 142, 148 (2d Cir. 1981)). The court of appeals explained that " $[\mathrm{i}] \mathrm{n}$ making that determination, this Court may consider all of the resources that the New York Court of Appeals could use, including New York's stated policies and the law of other jurisdictions." Id. (citation omitted).

${ }^{253}$ Id. at 109. 
York courts would impose a duty of reasonable diligence in attempting to locate stolen property." ${ }^{254}$ Applying this requirement to the case, the court held that DeWeerth's "minimal investigation" did not satisfy her duty of reasonable diligence and thus precluded her recovery of the painting. ${ }^{255}$ The judgment of the court of appeals became final when the Supreme Court denied DeWeerth's petition for a writ of certiorari. ${ }^{256}$

Three years later, in Solomon $R$. Guggenheim Foundation v. Lubell, ${ }^{257}$ the New York Court of Appeals had occasion to address the "unresolved state law issue" decided by the Second Circuit in DeWeerth. The Guggenheim Foundation, which operates the Guggenheim Museum in New York City, sued Lubell, seeking to recover a work by Marc Chagall that was stolen from the Museum by an employee in the late 1960s. Lubell purchased the Chagall in good faith from a well-known art gallery in 1967. In 1985, an art dealer, acting on behalf of Lubell, sought an auction estimate from Sotheby's. Sotheby's recognized the work as stolen and contacted the Guggenheim. The Museum subsequently wrote a letter to Lubell demanding the return of the Chagall. Lubell refused, and the Museum brought suit in state court. ${ }^{258}$

Relying on the Second Circuit's decision in DeWeerth v. Baldinger, the trial court granted Lubell's motion for summary judgment on the ground that the Museum failed "to use reasonable efforts to locate its missing property. ${ }^{259}$ The appellate division held that summary judgment was inappropriate because several issues of fact were in dispute, including the reasonableness of the Museum's actions following the theft of the Chagall. ${ }^{260}$

The New York Court of Appeals affirmed, but on somewhat different grounds. The court chose to adhere to traditional principles of New York law, and concluded "that the Second Circuit should not have imposed a duty of reasonable diligence on the owners of stolen

${ }^{254}$ Id. at 108. The Second Circuit "elected not to [certify] the unresolved state law issue in this appeal to the New York Court of Appeals" because the court did not think that the issue would "recur with sufficient frequency to warrant use of the certification procedure." Id. at 108 n.5.

${ }^{255}$ Id. at 112.

${ }^{256}$ See DeWeerth v. Baldinger, 486 U.S. 1056 (1988) (denying petition for a writ of certiorari).

${ }^{257} 569$ N.E.2d 426 (N.Y. 1991).

${ }^{25 s}$ See id. at $427-28$.

259 Id. at 429.

${ }^{260}$ See id. 
art work." ${ }^{261}$ The court specifically rejected the Second Circuit's decision to favor good-faith purchasers over the original owners, and concluded that "plac[ing] the burden of locating stolen artwork on the true owner... would... encourage illicit trafficking in stolen art." ${ }^{262}$ According to the court, "the better rule gives the owner relatively greater protection and places the burden of investigating the provenance of a work of art on the potential purchaser. ${ }^{263}$ Thus, the court declared that "the demand and refusal rule ... remains the law in New York and that there is no reason to obscure its straightforward protection of true owners by creating a duty of reasonable diligence. ${ }^{264}$

Encouraged by this development, DeWeerth sought relief from the judgment pursuant to Federal Rule of Civil Procedure 60(b) (6), which permits the district court to "relieve a party ... from a final judgment" for "any ... reason justifying relief from the operation of the judgment." ${ }^{265}$ The district court granted DeWeerth's motion "[i]n order to prevent the working of an extreme and undue hardship upon plaintiff, to accomplish substantial justice and to act with appropriate regard for the principles of federalism which underlie our dual judicial system in this extraordinary case. ${ }^{266}$ Although recognizing "the interest in finality of litigation," the district court stressed that "[f]ailure to act on the present Rule 60 motion would deny Mrs. DeWeerth the right to recover her property solely because she initially brought this action in federal rather than state court." 267 "Such inconsistency," the court concluded, "is exactly the type of result that Erie was enacted to avoid. ${ }^{263}$

DeWeerth's victory, however, was again short lived. On appeal, the Second Circuit reversed the judgment on the ground that the district court "abused its discretion in ordering relief from the final judgment based on Rule 60(b). ${ }^{269}$ The court began by reasserting the validity of the predictive model that it had employed: "When confronted with an unsettled issue of state law, a federal court sitting

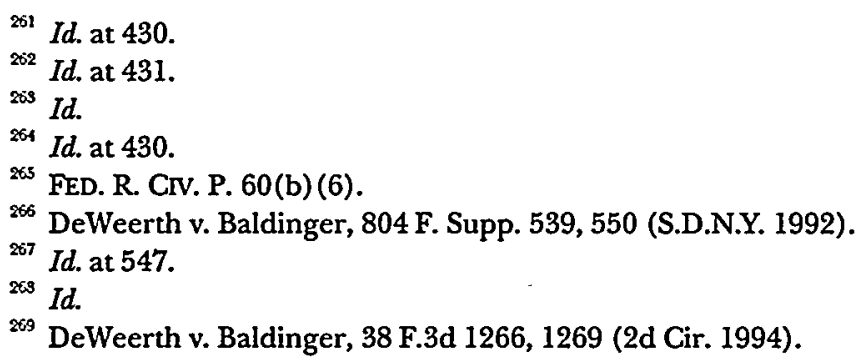


in diversity must make its best effort to predict how the state courts would decide the issue. ${ }^{\text {"270 }}$ Although acknowledging that its prediction of state law turned out to be wrong in this case, the court suggested that this risk is inherent in "our dual justice system." ${ }^{271}$ The court reasoned that " $[\mathrm{t}]$ here is nothing in Erie that suggests that consistency must be achieved at the expense of finality, or that federal cases finally disposed of must be revisited any time an unrelated state case clarifies the applicable rules of law."272 Rather, according to the court, Erie and its progeny require only "that the prior DeWeerth panel [have] conscientiously satisfied its duty to predict how New York courts would decide the due diligence question." ${ }^{273}$

DeWeerth illustrates the perils of the predictive approach, this time in the context of a federal court's adoption of a novel state-law defense. Existing New York law established a "demand and refusal rule" by which to calculate the applicable three-year statute of limitations. ${ }^{274}$ According to the New York Court of Appeals, the Second Circuit "obscure[d] [the rule's] straightforward protection of true owners by creating a duty of reasonable diligence. ${ }^{2775}$ Although denominated a prediction, the Second Circuit's "creation" of this novel defense in favor of current possessors of stolen art nonetheless raises substantial judicial federalism concerns under Erie. The decision whether to recognize such a defense turns on various conflicting policy considerations. The relative weight to be given to these considerations, as well as the balance to be struck among them, necessarily requires courts "to exercise the sovereign prerogative of choice. ${ }^{276}$ As interpreted in Erie, the Constitution assigns this prerogative not to the federal courts, but either to the states-acting through their legislatures and courts; or to the political branches of the federal government-acting in accordance with the procedural and political safeguards of federalism. When these organs fail to act, Erie establishes that federal courts have "no power to declare substantive rules of common law" on their behalf. ${ }^{277}$

${ }^{270} I d$. at 1273 .

${ }^{271}$ Id. at 1274; see also id. at 1273-74 ("The very nature of diversity jurisdiction leaves open the possibility that a state court will subsequently disagree with a federal court's interpretation of state law.").

${ }^{272} I d$. at 1274 .

${ }^{273} I d$.

${ }^{274} I d$.

${ }^{275}$ Solomon R. Guggenheim Found. v. Lubell, 569 N.E.2d 426, 430 (N.Y. 1991).

${ }^{276}$ Holmes, supra note 49 , at 461 .

${ }^{277}$ Erie, 304 U.S. at 78. 
In addition to infringing upon the constitutional "'autonomy and independence of the States, ${ }^{278}$ the federal courts' use of the predictive model gives rise to several of the "political and social" defects identified in Erie, ${ }^{279}$ such as inequitable administration of state law. DeWeerth is again illustrative. When a federal court employs the predictive approach and recognizes a novel cause of action or defense, and the state's highest court subsequently declines to adopt such law-as in DeWeerth-it is hard to escape the conclusion that the use of the predictive approach causes rights governed by state law to "vary according to whether enforcement was sought in the state or in the federal court. ${ }^{280}$ Had DeWeerth's claim been litigated in state court, she presumably would have regained possession of the Monet. ${ }^{281}$ Because DeWeerth brought her claim in federal court, however, Baldinger was permitted to retain the painting. As Erie observed, variation of this kind gives rise to both "injustice and confusion." 282

${ }^{278}$ Id. (quoting Baltimore \& Ohio R.R. Co. v. Baugh, 149 U.S. 368, 401 (1893) (Field, J., dissenting)).

${ }^{279}$ Id. at 74.

${ }^{280}$ Id. at 7475. By permitting state and federal courts to apply different law, the predictive approach may also encourage forum shopping if a party thinks that the federal courts will be more receptive than the state courts to a novel claim or defense.

${ }^{281}$ Of course, this assumes that state courts would have refused to impose a duty of reasonable diligence on DeWeerth. The fact that a state court could have imposed such a duty, however, would not give rise to inequitable administration of the law, even if the state's highest court subsequently rejected the duty in another case. Unlike federal courts, lower state courts have power to adopt law on behalf of a state. Thus, by definition, if a state court recognized a duty of reasonable diligence, then DeWeerth's right to recover the painting would have been determined in accordance with state law. See West v. AT\&T Co., 311 U.S. 223, 236 (1940) (explaining that rules established by judicial decisions of state courts are state laws); Six Cos. v. Joint Highway Dist. No. 13, 311 U.S. 180, 188 (1940) (referring to West and reversing the court of appeals based on its refusal to apply state law announced by a state appellate court); Fidelity Union Trust Co. v. Field, 311 U.S. 169, 177 (1940) (holding that federal courts must apply state law when it "supplies the rule of decision"). The inequitable administration of the law with which Erie is concerned stems not from the fact that the law applied in state courts may change over time, but from the fact that the applicable law varies from federal to state court at the time the case is adjudicated in federal court. See Erie, 304 U.S. at $74-75$ (stating that Swift "introduced grave discrimination" by making "rights enjoyed under the unwritten 'general law' vary according to whether enforcement was sought in the state or in the federal court" ${ }^{n}$ ).

${ }^{232}$ Erie, 304 U.S. at 77. Abandoning the predictive approach and applying only preexisting, determinate rules of state law arguably would alleviate these concerns. Although such a "static" approach would highlight the disparity between the lawmaking powers of federal and state courts-and thus encourage forum shopping-this approach should reduce the inequitable administration of state law because federal courts would restrict themselves to the application of determinate rules adopted by agents of the state and refuse to predict future changes. On the other hand, the static 


\section{Prediction That State Precedent Will Be Overmuled}

A federal court's refusal to apply existing state court precedent based on a prediction that such precedent will be overruled warrants distinct consideration. In some ways, this practice is even more problematic than the other uses of the predictive approach discussed above. Mason v. American Emery Wheel Works ${ }^{283}$ illustrates the difficulties with such a practice. Mason, a citizen of Mississippi, sued American Emery Wheel Works, a Rhode Island corporation, in federal court in Rhode Island, seeking to recover "in tort for personal injuries alleged to have been suffered by the plaintiff in Mississippi as a result of negligent misfeasance by the defendant in putting out in commerce without adequate care and inspection a dangerously defective emery wheel." ${ }^{284}$ The district court "reluctantly" concluded that the defendant company was not liable to Mason because, "“contrary to the great weight of authority' elsewhere," Mississippi law-as set forth in a 1928 Mississippi Supreme Court decision-did not recognize tort liability where there was no privity of contract between the parties. ${ }^{285}$

On appeal, the First Circuit predicted that the Supreme Court of Mississippi would "reconsider and revise" the privity requirement it embraced in 1928 "whenever it may have before it a case that squarely presents the issue," and "declare itself in agreement with the more enlightened and generally accepted modern doctrine." of appeals implemented this prediction by reversing the district court's grant of summary judgment in favor of the defendant and by remanding the case to the trial court for further proceedings. Relying on the First Circuit's prediction of Mississippi law, the Fifth Cir-

approach might give rise to an analogous kind of inequity by preventing recognition of a novel claim or defense that the relevant state's courts are prepared to adopt. For further discussion of the static approach, see infra Part IV.

241 F.2d 906 (1st Cir. 1957).

${ }^{284}$ Id. at 907.

${ }^{285}$ Id. at 908 (citing Ford Motor Co. v. Myers, 117 So. 362 (Miss. 1928)).

${ }^{286} I d$. at 910 . The First Circuit based its prediction, in part, on a relatively recent opinion by the Supreme Court of Mississippi, E.I. Du Pont de Nemours $\mathcal{E}^{2}$ Co. v. Ladner, 73 So. 2d 249, 254-55 (1954). The First Circuit wrote that the Mississippi court "indicate[d] its awareness of the modern trend in the area," even though it "was able to dispose of the particular issue on another ground without the necessity of expressly overruling its earlier decision." Mason, 241 F.2d at 909. The First Circuit's action, however, remained a prediction of future changes in state law rather than an interpretation of existing law. As the concurrence observed, " $[w]$ e . . have inferred from pure dicta in the Du Pont case and from the status of the law elsewhere on this issue that Mississippi is prepared to discard the [old] rule and adopt the modern rule." Id. at 910 (Hartigan, J., concurring). 
cuit subsequently ruled in several additional cases that lack of privity does not bar recovery by the plaintiff. ${ }^{287}$ These predictions ultimately came true in 1966 when the Supreme Court of Mississippi finally reconsidered the privity requirement, overruled its prior decision, and recognized a cause of action against a manufacturer even though privity of contract was lacking. ${ }^{288}$

The federal courts' use of the predictive approach in these cases raises judicial federalism concerns similar to those observed in other contexts. For nine years (from 1957 to 1966), federal courts recognized and applied "substantive rules of common law" that Mississippi had yet to adopt (and might have never adopted). To be sure, existing state law-as declared by the state's highest court in a decision-may be less "enlightened" than the law that a federal court thinks the state will ultimately adopt. The principles of judicial federalism underlying Erie, however, suggest that federal courts should refrain from exercising the substantial policymaking discretion necessary to make such judgments. Rather, federal courts should adhere to existing state-law rules of decision unless and until agents of the state see the light and exercise state legislative or judicial power to change state law, or appropriate agents of the federal government preempt such law by adopting positive federal law consistent with the various procedural and political safeguards specified in the Constitution. A federal court's failure to apply existing manifestations of state law while waiting to see if its prediction comes true arguably deprives states of their constitutional prerogative to regulate the rights and duties of parties who litigate their cases in federal court. Thus, at least with respect to such parties, the federal courts' use of the predictive approach effectively transfers from state to federal courts the power to "utter the last word" on matters governed by state law. ${ }^{290}$

${ }^{237}$ See Necaise v. Chrysler Corp., 335 F.2d 562, 572-73 (5th Cir. 1964) (agreeing with the First Circuit's prediction in Mason that Mississippi courts would no longer require privity of contract to recover for breach of duty of care); Grey v. HayesSammons Chem. Co., 310 F.2d 291, 297 (5th Cir. 1962) (same); see also Putman v. Erie City Mfg. Co., 338 F.2d 911, 912 (5th Cir. 1964) (relying on Mason to dispense with privity requirement in Texas despite Texas case law to the contrary).

${ }^{233}$ See State Stove Mfg. Co. v. Hodges, 189 So. 2d 113, 118 (Miss. 1966). Interestingly, in overruling its prior precedent, the Supreme Court of Mississippi cited neither the First Circuit's nor the Fifth Circuit's prediction of Mississippi law.

${ }^{289}$ Erie, 304 U.S. at 78.

${ }^{250}$ Id. at 79 (quoting Black \& White Taxicab \& Transfer Co. v. Brown \& Yellow Taxicab \& Transfer Co., 276 U.S. 518, 535 (1928) (Holmes, J., dissenting)). In addition, as Judge Sloviter has observed: 
Mason, however, raises an additional concern. Unlike Bulloch and DeWeerth, in which federal courts predicted and applied novel statelaw claims and defenses in the absence of state court decisions adopting such rules, ${ }^{291}$ Mason predicted and applied a cause of action that the state's highest court had previously considered and rejected. Thus, in addition to deciding the case against the ordinary background presumption in favor of private ordering, the Mason court had before it a specific affirmation of this presumption by the state's highest court in a case similar to the one before the court. In this sense, the Mason court appears not merely to have usurped the dormant lawmaking power of the state, but affirmatively to have disregarded an extant rule of decision adopted by the state's "highest court in a decision."

For all of the foregoing reasons, the lower federal courts' general practice of predicting how state courts would resolve novel or unsettled questions of state law-and then applying such predictions to govern the rights and duties of litigants in federal court-raises substantial constitutional concerns under the principles of judicial federalism recognized in Erie. ${ }^{293}$ As discussed in the next Part of this

Until [resolved definitively] by the state supreme court, such ... predictions inevitably skew the decisions of persons and businesses who rely on them and inequitably affect the losing federal litigant who cannot appeal the decision to the state supreme court; they may even mislead lower state courts that may be inclined to accept federal predictions as applicable precedent.

Sloviter, supra note 194, at 1681.

${ }^{291}$ See supra Part II.A-B.

${ }^{292}$ Erie, 304 U.S. at 78. Arguably, the passage of time, subsequent dicta by the state supreme court, and the development of a contrary trend in other states combined to render the rule established by the precedent indeterminate as applied in Mason. Even so, given the background presumption against liability, such indeterminacy would provide no warrant for granting a cause of action in the absence of a clear rule of state law to that effect. (Notice that if the situation had been reversed, and the precedent had established a cause of action that was later rendered indeterminate, such indeterminacy might provide a justification for a federal court to refiuse to apply a cause of action.) In any event, there is a strong argument that a federal court should always adhere to state supreme court precedent unless and until overturned by subsequent state legislation or judicial decision. Cf. Rodriguez de Quijas v. Shearson/Am. Express, Inc., 490 U.S. 477, 484 (1989) (asserting that lower federal courts should follow controlling Supreme Court precedent, "leaving to this Court the prerogative of overruling its own decisions"); id. at 486 (Stevens, J., dissenting) (asserting that the court of appeals' refusal to follow "a controlling precedent of this Court" constituted "an indefensible brand of judicial activism").

${ }^{293}$ The predictive approach also raises several practical problems for federal courts, such as "[ $t]$ he proper deference to be accorded a prior prediction of state law." Bergman, supra note 192 , at 986 . Bergman argues that " $[t]$ he current treatment of predictive precedents in the federal courts admits of two salient flaws: it is erratic in its application, and most governing standards accord too much deference to precedent, 
Article, these concerns appear to have led the Supreme Court itself to recognize abstention as at least a partial alternative to federal court prediction of state law.

\section{ERE-BASED ABSTENTION}

Although the Supreme Court's opinions contain dicta suggesting that federal courts should employ a predictive approach, the Court has neither squarely endorsed that model nor suggested that such an approach is the exclusive means that federal courts must employ to resolve unsettled questions of state law. To the contrary, on several occasions, the Court has reacted to judicial federalism concerns by permitting, or even requiring, federal courts to abstain from adjudicating cases that present such questions. The first section of this Part examines the limited circumstances in which the Court has approved abstention in cases presenting novel questions of state law. The second section concludes that although broader use of abstention in such cases might alleviate judicial federalism concerns, it would raise countervailing concerns based on the constitutional separation of powers.

\section{A. The Development of Erie-Based Abstention}

Just two years after deciding Erie, the Supreme Court held in Thompson v. Magnolia Petroleum Co. that district courts must "consent to submission to state courts of particular controversies involving unsettled questions of state property law and arising in the course of bankruptcy administration. ${ }^{294}$ In Thompson, the district court, sitting as a bankruptcy court, was called upon to decide whether a railroad in reorganization under the Bankruptcy Act had fee-simple ownership of certain right-of-way lands "with consequent right to reduce the under-

thus contravening Erie" Id. at 1001-02; see also id. at 1018 (proposing that "predictive precedents should bind presumptively, but a litigant's presentation of substantial evidence of a change in state law would be sufficient to rebut the presumption and to trigger a duty to exercise independent judgment"). A related problem is the extent to which one federal court of appeals owes deference to another's prediction of state law. See, e.g., Factors Etc., Inc. v. Pro Arts, Inc., 652 F.2d 278, 283 (2d Cir. 1981) (holding that the Second Circuit owed binding deference to the Sixth Circuit's prediction of Tennessee law). But cf. Salve Regina College v. Russell, 499 U.S. 225, 231 (1991) (holding that federal circuit courts owe no deference to federal district courts' determinations of state law).

${ }^{294} 309$ U.S. 478,483 (1940). 
lying oil to possession" ${ }^{295}$ or had "a mere easement-a limited right to use the surface for railroad purposes only."296 The district court ordered "the fugitive oil captured and its proceeds impounded pending adjudication of the ownership." ${ }^{297}$ The Eighth Circuit reversed, holding that, "as interpreted under Illinois law, the instruments relied on by the [railroad] conveyed an easement only." 298 The Supreme Court granted certiorari, in part, because the Eighth Circuit's interpretation of Illinois law conflicted with the Seventh Circuit's interpretation of substantially similar conveyances under Illinois law to confer feesimple ownership. ${ }^{299}$

Significantly, the Supreme Court did not resolve the conflict by predicting how the Supreme Court of Illinois would have construed the instruments in question. Rather, noting the absence of "clearly applicable" state statutes and decisions, ${ }^{300}$ the Court "conclude[d] that it is desirable to have the litigation proceed in the state courts of Illinois." ${ }^{301}$ Citing Erie, the Court reasoned as follows:

Unless the matter is referred to the state courts, upon subsequent decision by the Supreme Court of Illinois it may appear that rights in local property of parties to this proceeding have-by the accident of federal jurisdiction-been determined contrary to the law of the State, which in such matters is supreme.

Accordingly, the Court remanded the case to the district court "with instructions to modify its order so as to provide appropriate submission of the question of fee simple ownership of the right of way to the Illinois state courts." ${ }^{303}$

Thus, in Thompson, the Supreme Court recognized that resolution of unsettled questions of state law by federal courts raises substantial judicial federalism concerns and responded by requiring abstention. Because state law was indeterminate, the Court had no way of ascertaining state law with sufficient precision to resolve the dispute. The Court could have predicted what rule of law the Illinois Supreme Court would have adopted if the case were before it, but it found that

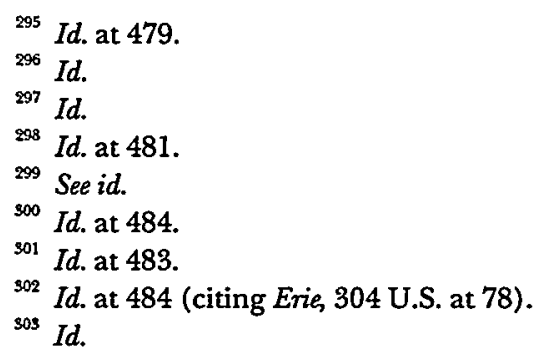


course to be unsatisfactory in light of the potential for inequitable administration of the law.

The Supreme Court recognized a related form of abstention three years later in Burford $v$. Sun Oil $\mathrm{Co}^{304}$ There, the plaintiff brought suit in federal court, on the basis of diversity and federalquestion jurisdiction, to enjoin enforcement of an order of the Texas Railroad Commission permitting the defendant to drill new wells in a particular oil field. ${ }^{305}$ Although the Commission had established a general rule and a series of exceptions to govern production of oil and gas, the Court nonetheless recognized that the application of Texas law to cases like this one was indeterminate because such application "clearly involves basic problems of Texas policy."306 Thus, the Court concluded that "a sound respect for the independence of state action requires the federal equity court to stay its hand" ${ }^{307}$ and "leave these problems of Texas law to the state court where each may be handled as "one more item in a continuous series of adjustments." As previously discussed, Erie suggests that such policy "adjustments" generally should be made by the states rather than the federal courts. $^{309}$

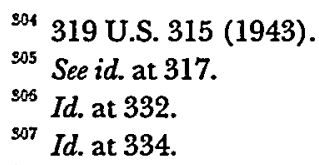

${ }^{203} I d$. at 332 (quoting Railroad Comm'n v. Rowan \& Nichols Oil Co., 310 U.S. 573, $584(1940)$ ). Justice Frankfurter argued in dissent that the Court's decision to deny the plaintiff access to federal court "disregard[s] a duty enjoined by Congress and made manifest by the whole history of the jurisdiction of the United States courts based upon diversity of citizenship between parties." Id. at 336 (Frankfurter, J., dissenting). Significantly, however, Justice Frankfurter acknowledged that "a court of equity may "avoid the waste of a tentative decision" where "the controlling state law is so undefined that a federal court attempting to apply such law would be groping utterly in the dark-where "no matter how seasoned the judgment of the district court may be, it cannot escape being a forecast rather than a determination." Id. at 338 (Frankfurter, J., dissenting) (quoting Railroad Comm'n v. Pullman Co., 312 U.S. 496, 499-500 (1941)). Thus, the point of disagreement between the majority and the dissent was not whether abstention is appropriate in a case presenting a truly novel question of state law, but whether the case before the Court presented such a question. Cf. infra note 489 and accompanying text (noting distinction between law application and law declaration). Compare Burford, 319 U.S. at 332 (stating that the questions raised "so clearly involve[] basic problems of Texas policy that equitable discretion should be exercised to give the Texas courts the first opportunity to consider them"), with id. at 340 (Frankfurter, J., dissenting) (arguing that "[ $t$ ] hese questions are not new" and that the Supreme Court of Texas has provided guidance "in a series of recent decisions").

${ }^{309}$ See supra notes $102-36$ and accompanying text. 
The case most commonly associated with Erie-based abstention, Louisiana Power $\mathcal{E}$ Light Co. v. City of Thibodaux, ${ }^{310}$ was not decided until 1959. There, the City of Thibodaux filed a petition in state court seeking to expropriate land, buildings, and equipment owned by the Louisiana Power \& Light Company. ${ }^{311}$ The company removed the case to federal court on the basis of diversity of citizenship, and the district court stayed the proceedings "until the Supreme Court of Louisiana has been afforded an opportunity to interpret" the statute upon which the city's expropriation order was based. ${ }^{312}$ The court of appeals reversed, but the Supreme Court reinstated the district court's action, emphasizing that eminent domain "is intimately involved with sovereign prerogative ${ }^{m 313}$ and that abstention in cases like this "reflect[s] a deeper policy derived from our federalism."

The Supreme Court found state law to be indeterminate because, although a state statute "apparently seems to grant" the city the power of eminent domain, the "statute ha[d] never been interpreted ... by the Louisiana courts," and the Attorney General of Louisiana had concluded in "a strikingly similar case" that another Louisiana city did not have such power. ${ }^{315}$ Thus, the Court concluded that abstention was appropriate, in part, to avoid the potential for inequitable administration of the law. If the Court had construed the statute to grant the city the power of eminent domain, and the state supreme court subsequently found in the statute "less than meets the outsider's eye," then "this case would be the only case in which the Louisiana statute is construed as [the Court] would construe it, whereas the rights of all other litigants would be thereafter governed by a [quite different] decision of the Supreme Court of Louisiana." these circumstances, the Supreme Court thought that the district

${ }^{310} 360$ U.S. 25 (1959).

\$11 See id. at 25.

312 Id. at 26 (quoting City of Thibodaux v. Louisiana Power \& Light Co., 153 F. Supp. 515, 518 (E.D. La. 1957)).

${ }^{313} I d$. at 28.

${ }^{314}$ Id.

S15 Id. at 30. The Court stressed that, despite the apparent power granted by the statute, the "statute has never been interpreted ... and it would not be the first time that the authoritative tribunal has found in a statute less than meets the outsider's eye. Informed local courts may find meaning not discernible to the outsider." Id. This seems to be merely another way of saying that state courts may sometimes interpret a state statute using methods of statutory construction that do not yield a clear answer, thereby leaving such courts free to exercise a certain amount of policymaking discretion. See supra notes 39-52 and accompanying text.

${ }^{316}$ Thibodaux, 360 U.S. at 30. 
judge- "rather than himself mak[ing] a dubious and tentative forecast" in "directing utilization of the legal resources of Louisiana for a prompt ascertainment of meaning through the only tribunal whose interpretation could be controlling-the Supreme Court of Louisiana. ${ }^{318}$

The Supreme Court last employed Erie-based abstention nine years later in Kaiser Steel Corp. v. W.S. Ranch Co., ${ }^{319}$ a diversity case in which the plaintiff alleged an illegal trespass by the defendant. Like Thompson and Thibodaux, Kaiser involved a question to which state law failed to provide a determinate answer. The issue in this case was whether a New Mexico water-rights statute, purporting to permit the defendant to trespass on the plaintiff's land in order to use certain water rights, constituted a permissible taking of private property for "public use" within the meaning of the New Mexico Constitution. ${ }^{320}$ While the case was on petition for rehearing in the Tenth Circuit, the defendant initiated a declaratory judgment action in state court in order to obtain a definitive resolution of this question. The Tenth Circuit, however, rejected the defendant's motion to stay the federal court proceedings pending adjudication of the state court action. ${ }^{321}$

In a brief per curiam opinion, the Supreme Court unanimously reversed and held that the Tenth Circuit "erred in refusing to stay its hand. ${ }^{322}$ The Court reasoned that the state law issue "is one of vital concern in the arid State of New Mexico" and that the "issue, moreover, is a truly novel one. ${ }^{323}$ In addition, as in Thompson and Thibodaux, the Court stressed the need to avoid inequitable administration of state law:

The question will eventually have to be resolved by the New Mexico courts.... Sound judicial administration requires that the parties in this case be given the benefit of the same rule of law which will apply to

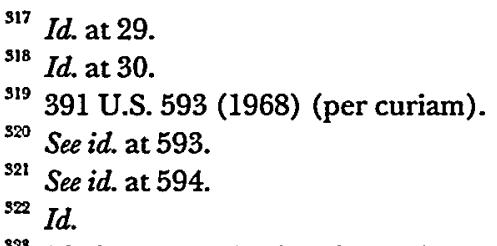

${ }^{223}$ Id. State constitutional questions of first impression qualify as "novel" questions of state law to the extent they require state courts to exercise a significant degree of policymaking discretion in interpreting various provisions of the state constitution. See supra notes 39-52 and accompanying text. 
all other businesses and landowners concerned with the use of this vital state resource. ${ }^{324}$

Accordingly, the Court remanded the case "with directions that the action be stayed in accordance with the [defendant's] prayer." ${ }^{325}$

Although permitting or requiring abstention on at least these three occasions, the Supreme Court has not gone so far as to suggest that mere difficulty in determining state law alone justifies broad Eriebased abstention. To the contrary, in Meredith $v$. Winter Haven, the Court declared "that the difficulties of ascertaining what the state courts may hereafter determine the state law to be do not in themselves afford a sufficient ground for a federal court to decline to exercise its jurisdiction to decide a case which is properly brought to it for decision." Erie, the Court admonished, "did not free the federal courts from the duty of deciding questions of state law in diversity cases." "327 Perhaps for this reason, the Court in Thibodaux stressed the "special nature of eminent domain," and the concurrence in Kaiser emphasized the presence of "special circumstances" arising from the fact that the question of state law at issue was "one of vital concern in the arid State of New Mexico, where water is one of the most valuable natural resources." ${ }^{329}$ Most recently, in Colorado River Water Conservation District v. United States, the Court restated these restrictions by describing Erie-based abstention as "appropriate where there have been presented difficult questions of state law bearing on policy problems of substantial public import whose importance transcends the result in the case ... at bar."

The Supreme Court's attempts to restrict Erie-based abstention, however, do not allay the judicial federalism concerns raised by the alternative of prediction. First, cases in which state law is indeterminate, by definition, "present[] difficult questions of state law." Thus, this first Colorado River criterion does not significantly limit the range of cases under discussion. Second, it is unclear how one is to decide which "questions of state law bear[] on policy problems of

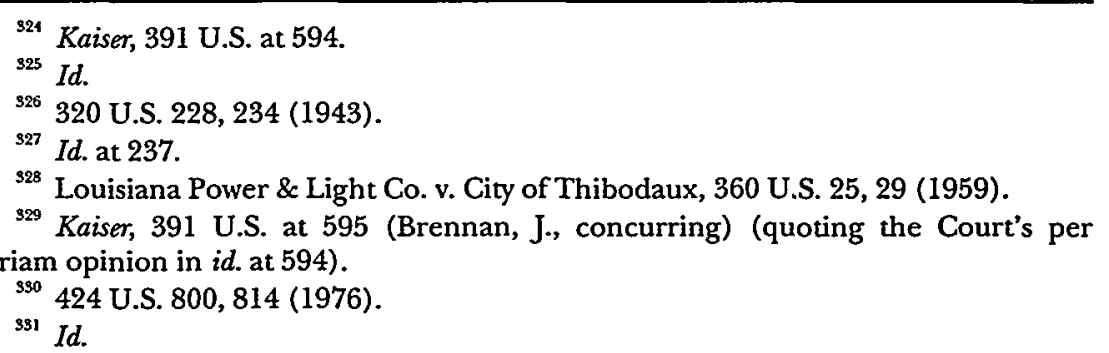


substantial public import" ${ }^{\text {392 }}$ and which do not. For example, it is difficult to see why the policy problem at issue in Thompson-whether railroads may recover oil and gas from right-of-way lands ${ }^{339}$-was of greater "public import" than the policy problem raised in Bullochwhether unmarried cohabitants may sue for loss of consortium. ${ }^{334}$ In any event, as interpreted in Erie, the Constitution generally reserves to the states substantive lawmaking power over all matters not governed by positive federal law, regardless of their relative "importance." 335

Finally, Colorado River gives no indication as to what the Court means by "policy problems of substantial public import whose importance transcends the result in the case . . . at bar." ${ }^{\text {"336 }}$ In diversity cases, either most cases presenting unsettled questions of state law involve problems that transcend the result in the case at bar, or almost none do. On the one hand, how a federal court resolves an open question of state law will often affect the rights of future litigants in federal court, especially when state courts do not authoritatively resolve the question for a substantial period of time. ${ }^{337}$ On the other hand, because federal-court predictions of state law are not binding in state court, such predictions necessarily apply only to a finite set of federal court litigants. $^{338}$ As DeWeerth shows, a state-acting through its courts-remains free to disregard federal court predictions in future cases and to "make just the opposite her law." act quickly to resolve unsettled questions, the threat that federal-court predictions pose to important state policies will not transcend, but in fact may be limited to, the case at bar. For example, in DeWeerth, the Second Circuit's erroneous prediction of state law thwarted implementation of New York's policy favoring recovery of stolen art in DeWeerth itself but did not prevent the New York Court of Appeals

${ }^{332} I d$.

s9s See supra text accompanying notes 295-96.

s94 See supra notes 211-24 and accompanying text.

${ }^{395}$ See supra notes 102-36 and accompanying text.

${ }^{306}$ Colorado River, 424 U.S. at 814.

s97 See supra notes 283-90 and accompanying text (discussing Mason v. American Emery Wheel Works, 241 F.2d 906 (1st Cir. 1957)). Moreover, federal court prediction of state law may itself delay state court resolution of unsettled questions of state law by drawing cases into federal court. See supra note 287 and accompanying text.

${ }^{339}$ Of course, there may be certain cases, perhaps involving class actions or review of state administrative orders, that could have a broader impact.

${ }^{339}$ Lehman Bros. v. Schein, 416 U.S. 386, 389 (1974). 
shortly thereafter from adopting the opposite rule to govern subsequent cases. $^{340}$

The potential for inequitable administration of the law is the only effect of federal-court prediction of state law that necessarily transcends the case at bar. As the Supreme Court stressed in Thompson, Thibodaux, and Kaiser, a federal court's insistence upon making "a dubious and tentative forecast ${ }^{\text {"341 }}$ regarding state law means that the parties before the court may not benefit from the law that would be applied to parties in state court. ${ }^{342}$ This risk, however, was just as great in Bulloch, DeWeerth, and Mason. The only sure way to eliminate the risk of inequitable administration is for federal courts to refrain from adopting novel rules of state law. Thus, if "effective judicial administration $^{\text {s43 }}$ and judicial federalism were the only considerations, they would actually favor expansion, rather than contraction, of Erie-based abstention in cases presenting novel questions of state law. ${ }^{344}$

\section{B. Erie-Based Abstention and the Separation of Powers}

Although judicial federalism arguably counsels greater reliance on Erie-based abstention, the Supreme Court has resisted expanding such abstention presumably because of countervailing separation-ofpowers concerns. ${ }^{345}$ As early as 1821, Chief Justice Marshall forcefully declared that the Court has "no more right to decline the exercise of jurisdiction which is given, than to usurp that which is not given. The

S40 supra notes $246-73$ and accompanying text.

34: Thibodaux, 360 U.S. at 29.

${ }^{342}$ See supra text accompanying notes $302,316,324$.

sis Thibodaux, 360 U.S. at 29.

${ }^{344}$ Judge Friendly appears to have reached a similar conclusion in Phillips, Nizer, Benjamin, Krim $\mathcal{E}$ Ballon v. Rosenstiel, 490 F.2d 509 (2d Cir. 1973), in which he argued in favor of granting "a timely motion for a stay pending [the] plaintiffs initiating appropriate proceedings in the New York courts." Id. at 516. Judge Friendly asserted that "[d]espite the expansive language used thirty years ago in Meredith $v$. Winter Haven, we do not believe that the Supreme Court today would demand that federal judges waste their time exploring a thicket of state decisional law in a case such as this." Id. (citation omitted) (footnote omitted). Judge Friendly defended his use of the word "waste," in part, on the ground that federal courts "cannot predict New York law with authority and [any] attempt to do so prevents a clarification by the state courts that would otherwise have occurred." Id. at 516 n. 8 .

${ }^{315}$ See George D. Brown, When Federalism and Separation of Powers Collide-Rethinking Younger Abstention, 59 GEO. WASH. L. REV. 114, 114 (1990) (stating that "a case can be made that the abstention doctrines present... a conflict between [the Supreme Court's] vision of federalism and its commitment to the separation of powers"). 
one or the other would be treason to the constitution. ${ }^{\text {"46 }}$ Statements of this sort appear to reflect the assumption that abstention in the face of apparently unqualified jurisdictional statutes "amounts to judicial lawmaking." ${ }^{\text {"47 }}$ Thus, Professor Redish has argued that abstention constitutes "judicial usurpation of legislative authority, in violation of the principle of separation of powers."

The Supreme Court's ambivalence towards Erie-based abstention reflects the inherent tension between abstention and the constitutional separation of powers. Just three years after the Court's decision in Thompson requiring abstention on the basis of judicial federalism, the Court rejected abstention in Meredith on the ground that the federal courts have a general "duty ... to decide questions of state law whenever necessary to the rendition of a judgment ${ }^{\mathbf{3 4 9}}$ in cases brought "within the jurisdiction conferred on the federal courts by Congress." stances" relating "to the discretionary powers of courts of equity, ${ }^{351}$ a federal court's decision to abstain "merely because the answers to the questions of state law are difficult or uncertain or have not yet been given by the highest court of the state, would thwart the purpose of the jurisdictional act." 352

Justice Brennan expanded upon these themes in his Thibodaux dissent. He began by asserting that "the imperative duty of a District Court, imposed by Congress under 28 U.S.C. $§ \S 1332$ and 1441, [is] to render prompt justice in cases between citizens of different

${ }^{346}$ Cohens v. Virginia, 19 U.S. 264, 403, 6 Wheat. 264, 404 (1821).

${ }^{317}$ Redish, supra note 20, at 115; see also Bergman, supra note 192, at 999-1000 ("Congress has enacted a statute opening the federal courts to suits between citizens of different states. Any limitations on that access should originate with the legislative branch, not with the judiciary." (footnotes omitted)).

${ }^{\text {ss }}$ Redish, supra note 20, at 76; see also Gene R. Shreve, Federal Injunctions and the Public Interest, 51 GEO. WASH. L. REV. 382, 415-16 (1983) (criticizing abstention on the ground that "the power to conduct the inquiry [into appropriate allocation of power between state and federal courts] and the processes suitable to its undertaking belong to Congress, not the federal judiciary").

349 Meredith v. Winter Haven, 320 U.S. 228, 234 (1943).

${ }^{350}$ Id. at 238.

351 Id. at $234-35$.

${ }^{352}$ Id.; see also Estate of Spiegel v. Commissioner, 335 U.S. 701,707 (1949) (holding that "the difficulty [of the state-law issues] involved did not relieve the Court of Appeals of its duty to make a decision"); Markham v. Allen, 326 U.S. 490, 495 (1946) ("The mere fact that the district court... is required to interpret state law is not in itself a sufficient reason for withholding relief to petitioner."). 
States." ${ }^{\text {353 }}$ Although acknowledging that abstention may be appropriate in exceptional cases, Justice Brennan thought that the Court's decision to order the parties "out of the federal court and into a state court in the circumstances of this case passe [d] beyond disrespect for the diversity jurisdiction to plain disregard of this imperative duty." ${ }^{354}$ Such disregard, he suggested, encroached upon Congress's power to establish and control the jurisdiction of the federal courts. ${ }^{355}$ In his view, separation of powers instructs that "[u]ntil Congress speaks otherwise, the federal judiciary has no choice but conscientiously to render justice for litigants from different States entitled to have their controversies adjudicated in the federal courts." ${ }^{356}$

Speaking subsequently on behalf of the Supreme Court in Colorado River, Justice Brennan referred to "the virtually unflagging obligation of the federal courts to exercise the jurisdiction given them." ${ }^{357}$ Most recently, in Quackenbush $v$. Allstate Insurance Co., the Court noted that it had "often acknowledged that federal courts have a strict duty to exercise the jurisdiction that is conferred upon them by Congress." ${ }^{358}$ At the same time, however, the Court recognized that "[t]his duty is not ... absolute" in light of the Court's "longstanding application" of various abstention doctrines. ${ }^{359}$ The difficulty arises when one attempts to reconcile the federal courts' duty to exercise their jurisdiction with the various doctrines permitting, or even requiring, them to abstain from exercising such jurisdiction. ${ }^{360}$

${ }^{333}$ Louisiana Power \& Light Co. v. City of Thibodaux, 360 U.S. 25, $31-32$ (1959) (Brennan, J., dissenting).

${ }^{354}$ Id. at 32 (Brennan, J., dissenting).

${ }^{355}$ See id. at 41 (Brennan, J., dissenting).

${ }^{556}$ Id. (Brennan, J., dissenting).

${ }^{337}$ Colorado River Water Conservation Dist. v. United States, 424 U.S. 800, 817 (1978); see also New Orleans Pub. Serv., Inc. v. Council of New Orleans, 491 U.S. 350 , 358 (1989) (stating that the Court's cases "support[] the proposition that federal courts lack the authority to abstain from the exercise of jurisdiction that has been conferred").

35s 116 S. Ct. 1712, 1720 (1996).

${ }^{359} I d$. at $1720-21$. One prominent, and perhaps unique, exception to this duty exists in the declaratory judgment context. See Wilton v. Seven Falls Co., 515 U.S. 277 (1995). According to the Court in Wilton, "the normal principle that federal courts should adjudicate claims within their jurisdiction" does not apply in this context, $i d$. at 288 , because "[s]ince its inception, the Declaratory Judgment Act has been understood to confer- on federal courts unique and substantial discretion in deciding whether to declare the rights of litigants," $i d$. at 286.

${ }^{300}$ It might be argued that the tension between federalism and separation of powers described in the text is somewhat artificial, at least in the context of Erie-based abstention. Specifically, if judicial federalism concerns render prediction inappropri- 
The Supreme Court's cases suggest a possible basis for reconciliation-the distinction between a stay of federal-court proceedings pending the outcome of state-court litigation and a dismissal of federal proceedings in favor of such litigation. ${ }^{361}$ Thibodaux and a similar case decided the same day, County of Allegheny $v$. Frank Mashuda Co., ${ }^{362}$ illustrate the point. In Thibodaux, the Court upheld a district court order staying proceedings in federal court "until the Supreme Court of Louisiana ha[d] been afforded an opportunity to interpret" the state statute that allegedly authorized the city to exercise its power of eminent domain. ${ }^{363}$ In Mashuda, by contrast, the Court rebuked a district court's attempt to dismiss a case in which "its diversity jurisdiction had been properly invoked" in order to avoid interfering with a state condemnation proceeding. ${ }^{364}$ Thus, in Quackenbush, the Court read these cases to "illustrate the distinction ... between abstentionbased remand orders or dismissals and abstention-based decisions merely to stay adjudication of a federal suit. ${ }^{365}$

ate in cases presenting unsettled questions of state law, then arguably the congressional statutes granting federal courts diversity jurisdiction are unconstitutional as applied to such cases (just as jurisdictional statutes are unconstitutional to the extent that they purport to extend federal-court jurisdiction to cases or controversies beyond those specified in Article III of the Constitution). Thus, the argument goes, a federal court's decision to forgo jurisdiction under these circumstances merely prevents Congress from encroaching on the constitutional prerogatives of the states, and does not improperly suspend a valid congressional directive. This argument might prove to be persuasive if the only options open to federal courts in cases of this kind were prediction and abstention. As discussed below, however, federal courts generally have two additional options - to employ the static approach or to invoke state certification procedures. See infra Parts IV (static approach), V (certification). Either of these options enables federal courts both to exercise jurisdiction and to alleviate judicial federalism concerns. Thus, the availability of these options undermines any suggestion that Eriebased abstention is necessary to avoid unconstitutional application of the relevant jurisdictional grants.

Sil See Thibodaux, 360 U.S. at 27 n.2 (distinguishing Meredith v. Winter Haven, 320 U.S. 228 (1943), on the ground that the court of appeals in that case had "directed the action to be dismissed" whereas the district judge in Thibodaux had "merely... stay[ed] disposition of a retained case until he could get controlling light from the state court").

${ }^{362} 360$ U.S. 185 (1959).

scs Thibodaux, 360 U.S. at 26 (quoting City of Thibodaux v. Louisiana Power \& Light Co., 153 F. Supp. 515, $517-18$ (E.D. La. 1957)).

${ }^{354}$ Mashuda, 360 U.S. at 188.

s6s 116 S. Ct. 1712, 1722-23 (1996). Although the distinction between a dismissal and a stay was undoubtedly important in these cases, an equally important distinction may have been that Thibodaux involved an unsettled question of statutory interpretation whereas Mashuda called upon the district court to apply "clear and certain" principles of state law. Mashuda, 360 U.S. at 196; see also Thibodaux, 360 U.S. at 31 (Stewart, J., concurring) (stressing that "there [was] no occasion in the interest of 
This distinction may ease the separation-of-powers concerns associated with some forms of abstention. As applied to Pullman abstention, ${ }^{366}$ for example, the distinction appears to have merit. Pullman abstention permits a federal court to stay proceedings based on federal-question jurisdiction and to require the parties to adjudicate an unsettled question of state law in state court whenever such adjudication may obviate the need for the federal court to resolve a substantial constitutional question. If the state courts' adjudication of the statelaw question establishes an adequate and independent state ground, then the federal court can comply with the relevant statute conferring federal-question jurisdiction by simply dismissing the case. If, on the other hand, the state courts' adjudication necessitates resolution of a federal constitutional question, then the federal court must exercise its jurisdiction to resolve it. Thus, such "partial abstention," as Professor Redish refers to it, "does not preclude the exercise of lower federal court jurisdiction; it merely delays it. For this reason, Pullman abstention might be deemed less of a judicial undermining of the congressional jurisdictional structure. ${ }^{\text {367 }}$

Whatever the merits of this line of defense as applied to Pullman abstention, it has little or no application to Erie-based abstention. In the typical candidate for Erie-based abstention, jurisdiction is based on diversity of citizenship rather than the presence of a federal question. Thus, these cases generally involve matters governed by state law. As discussed, dismissal of diversity cases in deference to state court proceedings raises serious separation-of-powers concerns because such action appears to thwart Congress's purpose in conferring diversity jurisdiction. ${ }^{363}$ In such cases, however, a federal court's decision to stay federal proceedings to permit adjudication of the case in state court will have virtually the same effect as a dismissal. Even if the state proceeding is limited to a declaratory judgment action, there

justice to refrain from prompt adjudication" in Mashuda "since the controlling state law [was] clear and only factual issues need[ed to] be resolved"). Thus, both judicial federalism concerns and separation-of-powers considerations made Thibodaux a better candidate for abstention than Mashuda.

${ }^{366}$ See Railroad Comm'n v. Pullman Co., 312 U.S. 496, 501 (1941) (holding that the federal district court should abstain from deciding a Fourteenth Amendment issue pending state court interpretation of a state statute).

${ }^{367}$ Redish, supra note 20, at 79 (footnote omitted). Professor Redish, however, ultimately concludes that none of the potential rationales "successfully defends the partial abstention model against a separation-of-powers attack." Id. at 80 .

${ }^{363}$ See id. at 78 (stating that "it is absurd to imagine that Congress would implicitly grant the courts authority effectively to repeal" a jurisdictional grant). 
may be little or nothing left for the federal court to do after the state court renders its judgment. If the state court resolves a state-law claim against the plaintiff or a state-law defense in favor of the defendant, then the federal court need only dismiss the case or perhaps enter judgment in favor of the defendant. If, on the other hand, the state court rules in favor of the plaintiff, then the federal court is at most required to consider the appropriate remedy. ${ }^{369}$

Another potential response to the separation-of-powers concerns raised by Eriebased abstention is to look to "the common-law background against which the statutes conferring jurisdiction were enacted. ${ }^{\text {370 }}$ The strongest form of this argument relies on the traditional power of courts of equity to "avoid the waste of a tentative decision" where "the controlling state law is so undefined that a federal court attempting to apply such law would be groping utterly in the dark-where 'no matter how seasoned the judgment of the district court may be, it cannot escape being a forecast rather than a cietermination." ${ }^{371}$ Thus, because Congress presumably was aware of this tradition when it conferred diversity jurisdiction on the federal courts, Erie-based abstention arguably raises fewer separation-ofpowers concerns in cases seeking only "equitable or other discretionary" relief than it does in cases seeking damages or other legal remedies. $^{372}$

if9 Although Quackenbush held that federal courts lack power "to dismiss or remand cases based on abstention principles... where the relief being sought is [damages rather than] equitable or otherwise discretionary" remedies, the Court found it "unnecessary to determine whether a more limited abstention-based stay order would have been warranted on the facts of this case." Quackenbush, $116 \mathrm{~S}$. Ct. at 1728.

${ }^{370}$ New Orleans Pub. Serv., Inc. v. Council of New Orleans, 491 U.S. 350, 359 (1989) (citing Shapiro, supra note 20, at 570-77).

${ }^{371}$ Burford v. Sun Oil Co., 319 U.S. 315, 338 (1943) (Frankfurter, J., dissenting) (quoting Pullman, 312 U.S. at 499-500); see also Pullman, 312 U.S. at 500 (stating that " $\mathrm{f}]$ ew public interests have a higher claim upon the discretion of a federal chancellor than the avoidance of needless friction with state policies").

${ }^{372}$ Quackenbush, 116 S. Ct. at 1728. Professor Redish maintains that "reliance on equitable principles as a means of avoiding friction within the federal system amounts to an historical non-sequitur." Redish, supra note 20 , at 89 . He reasons that "the doctrine of equity was developed in England, which knows no federal structure, ${ }^{n}$ id., and suggests that "a federal court may [not] appropriately decline to award equitable relief on grounds unrelated to traditional equitable concepts," id. at 86. Professor Shapiro disagrees, taking the position that:

[T] he exercise of equitable discretion need not be confined to those cases that would have fallen under the authority of the Chancellor before law and equity merged. The scope of that discretion should not be ruled by tradition 
A broader form of this argument suggests that common-law courts also traditionally possessed substantial discretion. In an influential article, Professor David Shapiro recounts that "two very significant areas of discretion lay at the heart of the jurisdiction of the commonlaw courts. The first involved the authority of those courts to issue the so-called prerogative writs," such as "certiorari, habeas corpus, mandamus, and prohibition." ${ }^{373}$ Although other common-law writs "came to be viewed as a matter of right,,"374 prerogative writs "were regarded as extraordinary; parties could not obtain the writs as a matter 'of course,' but only for cause shown to the satisfaction of the court; the issuing court awarded the writ at its discretion." ${ }^{\text {"75 }}$ The second area of discretion identified by Professor Shapiro is the doctrine of forum non conveniens, which gives a court discretion to dismiss a case within the letter of its jurisdiction given "the difficulty of litigating about events that took place far from the forum." ${ }^{\text {376 }}$ In light of these areas of common-law discretion, Professor Shapiro suggests that "a distinction between the common law courts and the courts of equity... cannot be sustained."

Whatever force Professor Shapiro's observations may have with respect to abstention in the areas he identifies, ${ }^{378}$ they do not eliminate entirely the separation-of-powers concerns raised by broad judicial discretion to decline jurisdiction over cases seeking traditional common-law remedies-such as damages-on the basis of traditional common-law causes of action-such as tort and contract. ${ }^{379}$ To be

alone; rather it should be informed by experience but remain sensitive to current needs and problems.

Shapiro, supra note 20 , at 580 (footnotes omitted).

${ }^{373}$ Shapiro, supra note 20 , at 572 (footnotes omitted).

${ }^{374}$ Id. at 571.

${ }^{375} I d$. at 572 .

376 Id. at 557 .

377 Id. at 571. Specifically, Professor Shapiro suggests that "the traditional discretion of courts of equity in deciding whether to exercise jurisdiction" confers discretion upon federal courts to abstain in common-law actions as well. Id. According to Professor Shapiro, "law and equity have long ceased to be separate systems, in both England and the United States, and thus arguments that discretion should be limited as if they were still separate seem a bit strained." Id.

${ }^{378}$ See id. at 572 ("The prerogative writs are of special interest because they often arose in the same kinds of cases in which contemporary federal courts have insisted on discretion in matters of jurisdiction-cases in which relief is sought against government officers, agencies, or tribunals for violation of a right or for failure to perform a legal duty.").

${ }^{379}$ The influential casebook that Professor Shapiro helps to edit maintains that "[d] espite Pullman's equitable foundations, the Court, without further discussion, has 
sure, the common-law background that Professor Shapiro describes with respect to prerogative writs and forum non conveniens may give rise to implied power on the part of federal courts to exercise discretion in these areas. ${ }^{330} \mathrm{But}$, as the Supreme Court has recently recognized, attempts by federal courts to expand their discretionary authority beyond these traditional common-law doctrines cannot be rationalized using this interpretive method, and thus continue to raise substantial separation-of-powers concerns. ${ }^{381}$

A final, but ultimately unpersuasive, attempt to justify Erie-based abstention involves the possibility of legislative ratification. ${ }^{382}$ It is true that Congress re-enacted the diversity statute as part of the comprehensive 1948 recodification of the Judicial Code, ${ }^{383}$ and that the Supreme Court by that time had recognized a form of abstention based, in part, on the unsettled condition of state law. ${ }^{384}$ Ratification theories, however, require firmer evidence than this of congressional assent to prior interpretations of recodified laws. To protect against the enactment of hasty or ill-considered legislation, the Constitution prescribes a deliberately elaborate and cumbersome process for

applied the doctrine to actions at law involving uncertain state law and potentially avoidable federal constitutional questions." RICHARD H. FALION ET AL., HART AND WECHSLER'S THE FEDERAL CouRTS AND THE FEDERAL SYSTEM 1236 (4th ed. 1996) [hereinafter HART \& WECHSLER] (citing Clay v. Sun Ins. Office, 363 U.S. 207 (1960)). Clay, however, involved certification rather than abstention, and thus raises fewer separation-of-powers concerns than traditional forms of abstention. See infra notes 488-92 and accompanying text.

sso See Quackenbush v. Allstate Ins. Co., 116 S. Ct. 1712, 1722 (1996) (holding that federal courts have the power to dismiss or remand cases based on abstention only when the relief sought is discretionary).

ssi See id. at 1724 (stating that although "the abstention doctrines and the doctrine of forum non conveniens proceed from a similar premise," the "abstention doctrine is of a distinct historical pedigree, and the traditional considerations behind dismissal for forum non conveniens differ markedly from those informing the decision to abstain").

${ }^{392}$ See Lorillard v. Pons, 434 U.S. 575, 580 (1978) (stating that "Congress is presumed to be aware of an administrative or judicial interpretation of a statute and to adopt that interpretation when it re-enacts a statute without change"). Code).

See Act of June 25, 1948, Pub. L. No. 773, 62 Stat. 869 (revising the Judicial

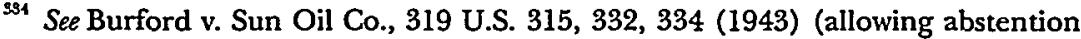
where questions of state policy were at issue); Thompson v. Magnolia Petroleum Co., 309 U.S. 478, 483 (1940) (allowing abstention where unsettled questions of property rights arose in the course of bankruptcy administration); supra notes 294-309 and accompanying text (noting that in Burford and Thompson, the Supreme Court "recognized that resolution of unsettled questions of state law by federal courts raises substantial judicial federalism concerns" ${ }^{n}$ ). 
transforming legislative purpose into binding law. ${ }^{385}$ Too potent a doctrine of ratification would shift the constitutionally assigned burden of legislative inertia, requiring Congress, in effect, to comb the judicial reporters and agency records for any interpretation that it wished to disavow as part of a recodification.

Thus, the Supreme Court has shown appropriate caution before concluding that mere reenactment of statutory language amounts to legislative endorsement of any statutory principle, however tenuous, that an agency or court has previously announced. ${ }^{386}$ For that reason, the Court has tended to limit ratification to "well established" interpretations, ${ }^{387}$ to "unanimous" court of appeals interpretations of statutes, ${ }^{388}$ or to administrative practices followed consistently for "many years." 389 In addition, the Court has looked for specific evidence of congressional awareness of the interpretation alleged to have been ratified. ${ }^{390}$

The Supreme Court's pre-1948 decisions in Burford and Thompson cannot support a claim of legislative ratification of broad Eriebased abstention for two reasons. First, when Congress recodified the diversity statute in 1948, no well-established principle authorized abstention in cases of unsettled state law. Rather, as discussed, the Court itself had announced in Meredith $v$. Winter Haven "that the difficulties of ascertaining what state courts may hereafter determine the state law to be do not themselves afford a sufficient ground for a federal court to decline to exercise its jurisdiction in a case which is properly brought to it for decision. ${ }^{\text {\$91 }}$ Second, the 1948 recodification supplies an especially poor vehicle for finding implied changes in the meaning of the civil code. As the Court has emphasized in general,

${ }^{3 s 5}$ See John F. Manning, Textualism as a Nondelegation Doctrine, 97 COLUM. L. REV. $672,707-10$ (1997) (arguing that features of the constitutionally prescribed legislative process, such as bicameralism and presentment, represent a deliberate sacrifice of governmental efficiency in the interest of checking possible legislative excess); supra notes 120-36 and accompanying text (stating that the Framers saw bicameralism, presentment, and the involvement of multiple actors in the federal legislative process as a way of checking the power of the federal government).

${ }^{386}$ See Zuber v. Allen, 396 U.S. 168, 185 (1969) (stating that "[l] egislative silence is a poor beacon to follow in discerning the proper statutory route").

${ }^{387}$ Lorillard, 434 U.S. at 580.

sss Albemarle Paper Co. v. Moody, 422 U.S. 405, 414 n.8 (1975).

${ }^{359}$ NLRB v. Gullett Gin Co., 340 U.S. 361, 365 (1951).

${ }^{390}$ See Zuber, 396 U.S. at 193 ("Nor in the present case has the Court's attention been drawn to any hearings that suggest that Congress acted with the particular administrative construction before it in either 1935 or 1937.").

${ }^{391} 320$ U.S. 228, 234 (1943). 
"it will not be inferred that Congress, in revising and consolidating the laws, intended to change their effect unless the intention is clearly expressed. ${ }^{392}$ The Court has expressly applied this background rule of construction to the 1948 revision. ${ }^{393}$ Moreover, even assuming that Congress's recodification of the civil code would permit limited Eriebased abstention, that recodification would not justify the broad expansion of such abstention necessary to eliminate the judicial federalism concerns associated with federal-court prediction of state law. Thus, given the strong background presumption that federal courts lack authority to decline to exercise unqualified statutory grants of jurisdiction, ${ }^{394}$ Eriebased abstention remains "at best an incomplete and problematic solution to the difficulty of ascertaining state law. ${ }^{\text {"95 }}$

The separation-of-powers concerns raised by Eriebased abstention are underscored by Congress's recent adoption of 28 U.S.C. $\$ 1367$ governing supplemental jurisdiction. ${ }^{396}$ Section 1367 was adopted in response to Finley $v$. United States, in which the Supreme Court refused to "read jurisdictional statutes broadly" to confer "what has become known as pendent-party jurisdiction, that is, jurisdiction over parties

${ }^{592}$ Anderson v. Pacific Coast S.S. Co., 225 U.S. 187, 199 (1912); see also United States v. Ryder, 110 U.S. 729, 740 (1884) (emphasizing the same point).

${ }^{393}$ See, e.g., Finley v. United States, 490 U.S. 545, 554 (1989) (stating, in reference to the 1948 recodification, that absent a clear expression of congressional intent to make changes in law or policy, such changes should not be inferred from the revised language); Fourco Glass Co. v. Transmirra Prods. Corp., 353 U.S. 222, 227 (1957) (stating that "no changes of law or policy are to be presumed from changes of language in the revision unless an intent to make such changes is clearly expressed").

${ }^{94}$ See, e.g., Cohens v. Virginia, 19 U.S. 264, 403, 6 Wheat. 264, 404 (1821) (Marshall, C.J.) ("We have no more right to decline the exercise of jurisdiction which is given, than to usurp that which is not given."); supra notes 345-58 and accompanying text (noting that in light of the broad federal grant of jurisdiction to the federal courts, abstention raises separation-of-powers concerns).

${ }^{995}$ Bergman, supra note 192, at 1000 . Similarly, periodic amendments of other parts of the diversity statute (such as the amount-in-controversy requirement) cannot sustain a claim that Congress acquiesced in Eriebased abstention by failing to repudiate it expressly. See, e.g., Central Bank, N.A. v. First Interstate Bank, N.A., 511 U.S. 164, 186 (1994) ('It does not follow... that Congress' failure to overturn a statutory precedent is reason for this Court to adhere to it.... Congress may legislate ... only through the passage of a bill which is approved by both Houses and signed by the President. Congressional inaction cannot amend a duly enacted statute." (citation omitted) (quoting Patterson v. McLean Credit Union, 491 U.S. 164, 175 n.1 (1989))); Helvering v. Hallock, 309 U.S. 106, 121 (1940) (Frankfurter, J.) ("[W]e walk on quicksand when we try to find in the absence of corrective legislation a controlling legal principle.").

${ }^{396}$ See Civil Justice Reform Act of 1990, Pub. L. No. 101-650, 104 Stat. 5089 (codified as amended at 28 U.S.C. $\$ 1367$ (1994)). 
not named in any claim that is independently cognizable by the federal court." scope of jurisdiction conferred by a particular statute can of course be changed by Congress." 398 Congress accepted this invitation and enacted $\S 1367$. Subject to several exceptions, $\S 1367$ (a) provides broadly that:

[I] n any civil action of which the district courts have original jurisdiction, the district courts shall have supplemental jurisdiction over all other claims that are so related to claims in the action within such original jurisdiction that they form part of the same case or controversy under Article III of the United States Constitution.

Thus, there is now a specific statutory mandate for federal courts to exercise jurisdiction in cases like Finley.

The statute, however, contains an important exception. Section 1367(c) gives the district courts discretion to "decline to exercise supplemental jurisdiction over a claim under subsection (a) if ... the claim raises a novel or complex issue of State law." doubtedly included this exception in order to safeguard federalism and "to promote justice between the parties, by procuring for them a surer-footed reading of applicable law." ${ }^{401}$ In addition, by expressly granting the federal judiciary discretion to abstain from exercising supplemental jurisdiction, Congress also dispelled any concern that the exercise of such discretion in this context violates the constitutional separation of powers. ${ }^{402}$ If Congress had understood the federal courts to possess such authority implicitly, then the explicit authorization set forth in 28 U.S.C. $\$ 1367$ (c) would have been quite

${ }^{397} 490$ U.S. 545,549 (1989).

${ }^{399} I d$. at 556 .

39928 U.S.C. $\$ 1367$ (a) (1994). The statute specifically responds to Finley by providing that "[s]uch supplemental jurisdiction shall include claims that involve the joinder or intervention of additional parties." Id.

${ }^{400}$ Id. $\S 1367(\mathrm{c})(1)$.

${ }^{101}$ United Mine Workers v. Gibbs, 383 U.S. 715, 726 (1966).

${ }^{402}$ The supplemental jurisdiction statute has been criticized for being "drafted in ... haste," and for "throw[ing] back to the courts" a variety of "problems that should have been anticipated easily and addressed in the statute." Richard D. Freer, Compounding Confusion and Hampering Diversity: Life After Finley and the Supplemental Jurisdiction Statute, 40 EMORY L.J. 445, 486 (1991). Although Professor Freer appears to be correct in his overall assessment, the important point for present purposes is that the statute's drafters at least had the foresight to include an express exception for claims that raise novel or complex issues of state law, thus obviating potential separation-of-powers objections when federal courts decline to adjudicate such claims. 
unnecessary. Thus, broad Erie-based abstention remains problematic in the absence of express congressional authorization.

In the end, the Supreme Court's tepid embrace of Eriebased abstention reflects the tension between judicial federalism and separation of powers when federal courts are presented with cases that raise unsettled questions of state law. On the one hand, abstention serves judicial federalism by preventing federal courts from usurping the lawmaking power of the states. On the other hand, in the absence of an express exception to applicable jurisdictional statutes, such abstention raises separation-of-powers concerns by threatening "congressional goals embodied in the seemingly unlimited grants of jurisdiction" to the federal courts. ${ }^{403}$ The Supreme Court's limited embrace of Eriabased abstention has done little to reconcile these competing and seemingly intractable constitutional concerns. ${ }^{404}$

\section{THE STATIC APPROACH}

A growing number of lower federal courts have responded to the constitutional difficulties posed by prediction and abstention by following a third approach. These courts essentially take a static view of state law by "rul[ing] upon state law as it presently exists" rather than "surmis[ing] or suggest[ing] its expansion." "405 Thus, contrary to the predictive approach, federal courts employing the static approach refuse even to consider requests that they recognize and apply novel rules of decision on behalf of the states. Rather, these courts will apply a rule of decision only after the state itself, acting through its legislature or its courts, has weighed the competing policy considerations and taken whatever steps are necessary to adopt the rule in

${ }^{103}$ Redish, supra note 20 , at 77-78.

${ }^{104}$ At least one commentator has concluded that federalism considerations trump separation-of-powers concerns in this context. See Calvin R. Massey, Abstention and the Constitutional Limits of the Judicial Power of the United States, 1991 BYU L. REV. 811. According to Professor Massey, "it is more plausible to regard the abstention doctrines as compelled by the Constitution" than "violative of the Constitution":

The constitutional roots of these doctrines lie in the mixed strand of textual, historical, and doctrinal arguments that combine to produce a powerful constitutional principle of structure: the idea that the judicial power of the United States is implicitly limited in order to preserve a zone of residual state authority to make and enforce the states' own law, free of federal interference.

Id. at 856.

${ }^{405}$ Tritle v. Crown Airways, Inc., 928 F.2d 81, 84 (4th Cir. 1990) (quoting Washington v. Union Carbide Corp., 870 F.2d 957, 962 (4th Cir. 1989)). 
question as a matter of state law. ${ }^{406}$ Although this static approach is structurally superior to prediction and abstention because it mitigates the judicial federalism and separation-of-powers concerns associated with these alternatives, it remains less than ideal because it nonetheless may give rise to difficulties analogous to the "political and social" defects identified in Erie. ${ }^{407}$

This Part first describes the static approach and briefly examines its application in a case presenting a novel question of state law. It next compares the static approach with the prediction and abstention models, and concludes that the static approach largely avoids the constitutional difficulties associated with these alternatives. Finally, this Part examines several countervailing concerns raised by federal courts' use of the static approach.

\section{A. Overview of the Static Approach}

The static approach follows largely from the principles of judicial federalism underlying Erie and the corresponding critique of the predictive model. ${ }^{408}$ Because Erie establishes that state "law in the sense in which courts speak of it today does not exist without some definite authority behind it, ${ }^{409}$ state law-so far as federal courts are concerned-consists solely of sovereign commands issued by appropriate agents of the state. Until such agents make the fundamental policy choices necessary to create new law on behalf of the state, principles of judicial federalism suggest that federal courts should adhere to the background presumption in favor of the status quo and thus have "no power to declare substantive rules of common law applicable in a State." ${ }^{\text {410 }}$ Accordingly, when state law applies in a determinate fashion-for example, by clearly establishing a cause of action or a defense in favor of one party or another-a federal court must apply such law to the case before it. On the other hand, when state law is indeterminate, the static approach instructs federal courts to refrain from making the significant policy choices necessary both to resolve such indeterminacies and to recognize a novel claim or

${ }^{106}$ See infra notes 433-35 and accompanying text.

${ }^{407}$ Erie, 304 U.S. at 74; see supra notes 96-98 and accompanying text (noting that the Swift doctrine led to forum shopping and inequitable administration of the law).

${ }^{403}$ See supra notes 195-209 and accompanying text.

${ }^{409}$ Erie, 304 U.S. at 79 (quoting Black \& White Taxicab \& Transfer Co. v. Brown \& Yellow Taxicab \& Transfer Co., 276 U.S. 518, 533 (1928) (Holmes, J., dissenting)); see supra notes $103-10$ and accompanying text.

${ }^{410}$ Erie, 304 U.S. at 78. 
defense. In other words, the static approach counsels federal courts to adjudicate the rights and duties of the parties without regard to novel rules proposed by the parties, but not yet recognized authoritatively by an appropriate organ of the state. Thus, unless the proponent of a novel rule is able to establish that the state itself-acting through its legislature, its courts, or other appropriate agents-has already exercised the policymaking discretion necessary to adopt the rule in question, a federal court employing the static approach will simply refuse to recognize the proposed rule. In this sense, the proponent of a proposed rule must establish that the rule in fact constitutes a sovereign command of the state and thus bears the risk of nonpersuasion.

The First Circuit's decision in Dayton v. Peck, Stow $\mathcal{E}$ Wilcox Co. ${ }^{411}$ illustrates the static approach. In that case, the plaintiff filed a products-liability action in federal court against two corporate affiliates, seeking to recover damages for personal injuries he sustained while using a metal-shearing machine manufactured in 1957 by the defendants' corporate predecessor. ${ }^{412}$ In 1963 , one of the defendants purchased the predecessor's assets for cash. ${ }^{413}$ The district court granted the defendants' motion for summary judgment on the ground that neither entity was liable as the original corporation's successor under Massachusetts law. ${ }^{414}$ The court of appeals affirmed on the basis of the traditional rule of Massachusetts law that "a company which purchases the assets of another company is not liable for the debts and liabilities of the transferor," recognized exceptions" ${ }^{\text {"16 }}$ to the general rule applied in this case. ${ }^{417}$

Nonetheless, the plaintiff urged the First Circuit "to import into Massachusetts law the "product line' theory developed" by the California Supreme Court. ${ }^{418}$ Under the product-line theory, "'a party [who] acquires a manufacturing business and continues the output of its line of products ... assumes strict tort liability for defects in units of the same product line previously manufactured and distributed by

439 F.2d 690 (1st Cir. 1984).

112 See id. at 691 .

11 See id.

it See id.

${ }^{15}$ Id. at 692 (quoting Araserv, Inc. v. Bay State Harness Horse Racing \& Breeding Ass'n, 437 F. Supp. 1083, 1089 (D. Mass. 1977)).

${ }^{116}$ Id.

${ }^{417}$ See id. at 692-94.

${ }^{418}$ Id. at 694 (citation omitted). 
the entity from which the business was acquired." ${ }^{419}$ The court rejected the plaintiff's invitation because it saw "no basis [in Massachusetts authority] for applying any rule other than the traditional one." ${ }^{420}$ Significantly, the First Circuit made no attempt to predict whether the Supreme Judicial Court of Massachusetts would adopt the "product line" theory. Rather, the court based its decision on the fact that Massachusetts had not yet done so:

[W] are in a particularly poor position, sitting as a federal court in a diversity case, to endorse the fundamental policy innovation implicit in the product line theory. Absent some authoritative signal from the legislature or the courts of Massachusetts, we see no basis for even considering the pros and cons of innovative theories of successor corporate liability. We must apply the law of the forum as we infer it presently to be, not as it might come to be. ${ }^{421}$

Accordingly, the First Circuit affirmed the district court's decision to grant summary judgment in favor of the defendants. ${ }^{42}$

Two related features of the approach employed by the Dayton court are worth noting. First, the approach rests on a positivist view of state law-that is, state law comes into existence only by virtue of "authoritative" action undertaken by "the legislature or the courts of

${ }^{119} I d$. (quoting Ray v. Alad Corp., 560 P.2d 3, 11 (Cal. 1977)).

${ }^{420} I d$. at 694-95.

421 Id. at 694 (footnote omitted). The court discounted "an unpublished memorandum and order of the Massachusetts Superior Court denying successor corporations' motions for summary judgment on the basis of the product line theory." Id. at $694 \mathrm{n} .5$. According to the court, " $[\mathrm{s}] \mathrm{uch}$ an order does not rise to the level of persuasive, let alone binding, precedential authority and we refuse to hinge our interpretation of existing Massachusetts law on it." Id. at $694-95$ n.5.

${ }^{122}$ See $i d$. at 695 . The First Circuit is not alone in applying a static approach to cases presenting novel questions of state law. See, e.g., Tritle v. Crown Airways, Inc., 928 F.2d 81, 84 (4th Cir. 1990) (stating that "[f]ederal courts are permitted under Erie... to rule upon state law as it presently exists and not to surmise or suggest its expansion" (alteration in original) (emphasis omitted) (quoting Washington $v$. Union Carbide Corp., 870 F.2d 957, 962 (4th Cir. 1989))); Anderson v. Marathon Petroleum Co., 801 F.2d 936, 942 (7th Cir. 1986) (stating that "federal court is not the place to press innovative theories of state law"); Afram Export Corp. v. Metallurgiki Halyps, S.A., 772 F.2d 1358, 1370 (7th Cir. 1985) (stating that "[f] ederal judges are disinclined to make bold departures in areas of law that we have no responsibility for developing"). Indeed, the Fifth Circuit appears to have employed a static approach in declining a similar request to apply product-line liability as a matter of Texas law:

We have no assurance whatever that Texas would adopt the product line rule of liability. That rule represents at least a radical extension of Texas product liability theory, at most a shift to a new and additional basis for liability. Neither action is appropriate for us. Whatever the merits or demerits of the proposed new rule, for us to adopt it for Texas would be presumptuous.

Rhynes v. Branick Mfg. Corp., 629 F.2d 409, 410 (5th Cir. 1980). 
Massachusetts." ${ }^{223}$ Second, the First Circuit's approach necessarily treats state law as relatively static - that is, the content of state law does not change unless an organ of the state makes "the fundamental policy innovation" necessary to change it. ${ }^{424}$ This approach does not permit federal courts to predict a state court's future adoption or modification of state law because principles of judicial federalism preclude federal courts from making such fundamental policy innovations on behalf of a state. Rather, federal courts are limited to applying state law as they "infer it presently to be, not as it might come to be. ${ }^{425}$ In other words, if the proponent of a novel claim or defense is unable to establish that an appropriate organ of the state has adopted the proposed rule as a matter of state law, then the federal court will simply decline to recognize or apply the rule on the ground that there is no law to apply. In light of the federal judiciary's lack of constitutional power "to declare substantive rules of common law applicable in a State," ${ }^{426}$ federal courts employing a static approach maintain that "[a] party who wants a court to adopt an innovative rule of state law should litigate in state rather than federal court." $^{427}$

\section{B. The Static Approach and the Constitutional Structure}

The static approach avoids both the judicial federalism concerns raised by the predictive approach, ${ }^{428}$ and the separation-of-powers concerns associated with abstention. ${ }^{429}$ In this regard, the static approach raises fewer constitutional difficulties than either prediction or abstention. Thus, standing alone, the constitutional structure suggests that federal courts should favor the static approach over these more problematic alternatives.

As previously discussed, the predictive approach raises judicial federalism concerns by permitting federal courts to make and im-

${ }^{123}$ Dayton, 739 F.2d at 694 . As the Supreme Court recognized in Erie, state courts, no less than state legislatures, make law on behalf of the state, and both sources of state law are equally binding in federal court. See supra notes 106-13 and accompanying text.

424 Dayton, 739 F.2d at 694.

${ }^{125} I d$.

${ }^{120}$ Erie, 304 U.S. at 78. 1985).

${ }^{427}$ Afram Export Corp. v. Metallurgiki Halyps, S.A., 772 F.2d 1358, 1370 (7th Cir.

${ }^{128}$ See supra notes $195-209$ and accompanying text.

${ }^{429}$ See supra notes $345-58$ and accompanying text. 
plement significant policy choices on behalf of a state before the state itself has adopted applicable rules of decision and without any assurance that it will do so. ${ }^{430}$ Thus, at least with respect to a limited class of cases, the predictive approach necessarily permits federal courtsrather than the political branches or the states- "to declare substantive rules of common law applicable in a State," in contravention of the structural inference recognized in Erie that federal courts lack constitutional power to do so. ${ }^{491}$ In this way, the predictive approach enables the federal government-acting through its courts-to evade the procedural and political safeguards of federalism and thereby to "invade rights ... reserved by the Constitution to the several States."

The static approach largely avoids judicial federalism concerns of this sort. Under the static approach, federal courts apply substantive rules of decision only to the extent that they constitute sovereign commands of the state-that is, only after they have been adopted or declared by an appropriate agent of the state, such as its legislature or judiciary. The requirement of adoption by an appropriate organ of the state eliminates the possibility that federal courts will usurp state lawmaking power by erroneously or prematurely making the fundamental policy choices that are necessary to recognize (and apply) novel rules of decision on behalf of a state. ${ }^{493}$ In this sense, "' [a] state claim which has not been recognized by state courts may well be a settled question of state law," "434 and the federal courts' refusal to predict the future course of state law arguably implements the background presumption in favor of the status quo under state law. ${ }^{435}$

130 See supra Part II.

131 Erie, 304 U.S. at 78 (stating that "no clause in the Constitution purports to confer such a power upon the federal courts").

${ }^{432}$ Id. at 80; see supra notes 195-209 and accompanying text (explaining how the predictive approach undermines constitutional procedures safeguarding federalism). In addition, to the extent that it permits federal courts to recognize rules of decision more favorable to litigants than existing state law, the predictive approach may also increase forum shopping and inequitable administration of the law, at least until the state acts definitively to establish binding rules of decision. See supra notes 278-82 and accompanying text.

135 See Rubinstein v. Collins, 20 F.3d 160, 172 (5th Cir. 1994) (suggesting that the static approach ensures that federal courts will not usurp state authority to "expand state law beyond its present existing boundaries").

${ }^{434}$ Tritle v. Grown Airways, Inc., 928 F.2d 81, 84 (4th Cir. 1990) (quoting Washington v. Union Carbide Corp., 870 F.2d 957, 962 (4th Cir. 1989)).

${ }^{135}$ See Shaw v. Republic Drill Corp., 810 F.2d 149, 150 (7th Cir. 1987) (per curiam) (stating that "[i]n the context of pendent state law claims, we have already indicated our unwillingness to speculate on any trends in state law"); supra notes 225-27 and accompanying text. 
Thus, the static approach operates to reserve state lawmaking power to agents of the state by preventing federal courts from circumventing the procedural and political safeguards of federalism. In addition, the static approach may reduce the incidence of forum shopping and inequitable administration of the law associated with the predictive approach by preventing federal courts from applying law more favorable to one party than is presently recognized by agents of the state. ${ }^{436}$

The static approach also alleviates the separation-of-powers concerns raised by abstention. Unlike abstention, which requires federal courts to refrain from exercising jurisdiction in favor of state court adjudication, the static approach permits federal courts to adjudicate on the merits all cases that fall within their jurisdiction. Although they refuse to recognize a novel state-law claim or defense on behalf of a state, federal courts employing the static approach nonetheless proceed to exercise jurisdiction and resolve the legal rights and duties of the parties according to the existing sovereign commands of the state or, in the absence of such commands, the background presumption in favor of the status quo. Thus, unlike abstention, the static approach cannot be said to nullify "the seemingly unlimited grants of jurisdiction" conferred by Congress upon the federal courts. ${ }^{437}$ In this regard, the static approach yields an important structural advantage over abstention.

\section{The "Political and Social" Defects of the Static Approach}

Although the static approach thus appears to conform more closely to the constitutional structure than either prediction or abstention, this approach nonetheless may give rise to several undesirable consequences. Just as the predictive approach may lead federal courts to recognize and apply novel rules of decision before state courts are prepared to adopt them, the static approach may lead federal courts to continue to apply existing rules of decision even after state courts are prepared to abandon them. In this sense, the static approach may perpetuate outmoded principles of state law by simultaneously drawing cases into federal court and depriving state courts of

${ }^{436}$ See supra notes 278-82 and accompanying text (noting that the predictive approach may promote forum shopping). Although the static approach reduces some of the conditions that lead to forum shopping and inequitable administration of the law, it also gives rise to countervailing conditions that may encourage comparable effects. See infra notes $438-39$ and accompanying text.

${ }^{197}$ Redish, supra note 20, at 77-78; see supra notes 345-58 and accompanying text. 
opportunities to adopt novel rules of state law. For this reason, like the predictive model, the static approach may lead to forum shopping and inequitable administration of the law. ${ }^{438}$ If federal courts employ the static approach, parties benefited by the status quo will inevitably seek to litigate their cases in federal, rather than state, court because federal courts will rule against the proponent of a novel claim or defense unless the party can establish that it has been adopted by an appropriate organ of the state. Thus, to the extent that a state court is prepared to adopt the rule in question but has not yet had an opportunity to do so, the static approach arguably makes it more likely that the law applied in federal and state court will differ based on the accident of diversity jurisdiction. ${ }^{439}$

This observation, however, does not suggest that federal courts should employ the predictive model over the static approach. As discussed, the former-unlike the latter-contradicts the principles of judicial federalism recognized in Erie. Moreover, both approaches will result in forum shopping on occasion. When the trend in state law is pro-plaintiff, for example, the static approach would encourage forum shopping by giving defendants a strong incentive to litigate in federal court, where existing state law would apply in their favor. By the same token, however, the federal courts' use of the predictive approach to anticipate this trend would encourage plaintiffs to adjudicate their claims in federal court, especially after a federal court has predicted a favorable development. ${ }^{40}$ Under these circumstances,

${ }^{433}$ From a positivist perspective, a federal court's refusal to recognize and apply state law that cannot be traced to the command of the state sovereign does not, strictly speaking, give rise to inequitable administration of state law because, at the time of the court's decision, the state has not yet acted to adopt such law. Nonetheless, in cases in which state courts would adopt a novel rule of state law if given the opportunity, the static approach does make it seem, at least in retrospect, that the law applied in federal court turned solely on the accident of diversity jurisdiction.

${ }^{439}$ Cf. Klaxon Co. v. Stentor Elec. Mfg. Co., 313 U.S. 487, 496 (1941) (requiring federal courts to apply state choice-of-law rules in order to prevent "the accident of diversity of citizenship" from "constantly disturb[ing] equal administration of justice in coordinate state and federal courts sitting side by side").

${ }^{440}$ Plaintiffs, of course, have even greater opportunities to steer cases into federal court than do defendants. Under the diversity statute, the plaintiff has the right to file suit in federal court regardless of whether the court is located in the plaintiff's or the defendant's state. See 28 U.S.C. $\$ 1332$ (a) (1994). The defendant, by contrast, has the right to remove a non-federal question case filed in state court only if the defendant is not "a citizen of the State in which such action is brought." See id. § 1441 (b). 
there is no apparent reason to conclude that one form of forum shopping is preferable to the other. ${ }^{441}$

Given that both the predictive and the static approaches have the potential to trigger forum shopping and inequitable administration of the law, the source of these defects may lie not in the particular approach that federal courts use to decide unsettled questions of state law, but in the very existence of federal jurisdiction over cases presenting such questions. The difficulty ultimately may stem from the relative institutional competence of federal and state courts to resolve unsettled questions of state law. As discussed, there is a fundamental disparity under the constitutional scheme between the ability of federal and state courts to adopt substantive rules of decision on behalf of the states. Whereas state courts undoubtedly possess such authority, "[f] ${ }^{442}$ ederal courts lack competence to rule definitively on the meaning of state legislation." ${ }^{443}$ In light of this disparity, federal courts-whether they employ the predictive approach or the static approach-simply cannot replicate the lawmaking function of the states. $^{444}$ For this reason, it is perhaps inevitable that any attempt by

${ }^{111}$ Mason v. American Emery Wheel Works, 241 F.2d 906 (1st Cir. 1957), discussed supra notes 283-90 and accompanying text, is illustrative. Assume that the Mason court had employed the static approach rather than the predictive model, and consequently had applied the traditional Mississippi requirement of privity of contract to bar recovery. This course would have eliminated the judicial federalism concerns raised by the predictive approach, but it arguably would have perpetuated a rule of law that the Mississippi Supreme Court may have been prepared to abandon. As previously noted, the federal court's prediction undoubtedly gave rise to forum shopping by subsequent plaintiffs and to some degree of inequitable administration of state law. See supra note 290 and accompanying text. On the other hand, had the Mason court employed the static approach and adhered to the privity requirement, future defendants would have had a similar incentive to steer their cases into federal court. Thus, in the end, both approaches may give rise to the "political and social" defects represented by forum shopping and inequitable administration of the law. See Erie, 304 U.S. at 7475.

${ }_{112}$ As the Supreme Court recognized in Erie, "whether the law of the State shall be declared by its Legislature in a statute or by its highest court in a decision is not a matter of federal concern." Erie, 304 U.S. at 78.

${ }^{443}$ Arizonans for Official English v. Arizona, 117 S. Ct. 1055, 1059 (1997); see Erie, 304 U.S. at 78 (stating that "no clause in the Constitution purports to confer such a power upon the federal courts"). For this reason, it is now universally recognized that federal courts must abandon their own conceptions of state law in the face of authoritative pronouncements by state courts to the contrary. See WRIGHT ET AL., supra note $179, \S 4507$.

"14 As the Court has recognized, when state law has a "highly doubtful meaning," Louisiana Power \& Light Co. v. City of Thibodaux, 360 U.S. 25, 31 (1959) (Stewart, J., concurring), a federal court's decision concerning "what is the law of the state .. cannot escape being a forecast rather than a determination." Id. at 27 (quoting Railroad Comm'n v. Pullman Co., 312 U.S. 496, 499 (1941)). 
federal courts to resolve unsettled questions of state law has the potential to produce some degree of forum shopping and inequitable administration of the law. ${ }^{45}$ As Part V of this Article will explain, however, it may nonetheless be possible on many occasions for federal courts to minimize these defects while simultaneously avoiding the federalism and separation-of-powers concerns associated with prediction and abstention. Federal courts can further these seemingly inconsistent goals by more frequent resort to a procedure generally permitted by the states and already employed by many federal courts-certification of unsettled questions of state law to the highest court of the state.

\section{Certification}

As the Supreme Court recently observed, "[m]ost States have adopted certification procedures. ${ }^{246}$ In fact, forty-three states now permit at least some federal courts to certify unsettled questions of state law to the highest court of the state for authoritative resolution. $^{447}$ Like the static approach, certification alleviates the judicial federalism and separation-of-powers concerns raised by prediction and abstention. Unlike the static approach, however, certification also avoids the "political and social" defects associated with that approach by reducing both the incentives for forum shopping and the potential for inequitable administration of the law. These advantages, as well as considerations of federal-state comity, suggest that federal courts should make greater use of this procedure.

This Part consists of three sections. The first section describes the nature of the certification procedure and its relatively recent rise during the latter half of this century. The second section proposes that federal courts employ a presumption in favor of certification whenever the procedure is available and they are presented with unsettled questions of state law that call for the exercise of significant

${ }^{445}$ Since Erie, the Supreme Court has at least suggested that the Constitution itself may require federal courts to avoid these defects. See, e.g., Hanna v. Plumer, 380 U.S. 460,468 (1965) (describing "the twin aims of the Erie rule" as "discouragement of forum-shopping and avoidance of inequitable administration of the laws"). In Erie, however, the Court clearly did not regard avoidance of these "defects" as a constitutional imperative. See supra notes $96-99$ and accompanying text. In any event, the socalled "twin aims" of Erie do not appear to counsel strongly in favor of either the predictive model or the static approach because neither appears to be capable of completely achieving these aims, whatever their source.

${ }^{416}$ Arizonans for Official English, 117 S. C. at 1073.

${ }^{417}$ See infra note 472 and accompanying text. 
policymaking discretion more appropriately left to the states. Such a presumption not only would alleviate the judicial federalism and separation-of-powers concerns raised by prediction and abstention, but also would reduce the risks of forum shopping and inequitable administration of the law posed by the static approach. Finally, the third section briefly evaluates several potential difficulties that federal courts might face if they attempt to implement a presumption in favor of certification.

\section{A. The Rise of Certification}

In Meredith $v$. Winter Haven, the Supreme Court declared that federal courts must generally decide difficult or unsettled questions of state law whenever "their jurisdiction is properly invoked" to avoid "thwart[ing] the purpose of the jurisdictional act." itself presented two unresolved questions of Florida law that the Court required the federal court of appeals to decide on remand. ${ }^{450}$ Thus, it is perhaps no coincidence that less than two years later, Florida enacted a statute authorizing federal appellate courts to certify, and the Supreme Court of Florida to answer, questions of state law whenever "there are no clear controlling precedents in the decisions of the supreme court of this state. ${ }^{451}$ This innovative certification procedure lay dormant, however, for more than fifteen years, apparently because the Supreme Court of Florida failed to adopt rules necessary to implement the statute.

In Clay v. Sun Insurance Office, the Supreme Court of the United States revived the procedure by praising the Florida legislature's "rare foresight" in authorizing certification, ${ }^{452}$ and suggesting that the court of appeals on remand attempt to obtain an authoritative determination of "two unresolved state law questions" by certifying them to the

${ }^{143} 320$ U.S. 228,234 (1943).

119 Id. at 235.

${ }^{150}$ See supra notes $185-89$ and accompanying text.

151 Act effective July 1, 1957, $1945 \mathrm{Fla}$. Laws ch. 23098, § 1 (codified at FLA. STAT. ANN. $\$ 25.031$ (West 1988)). The statute requires that the question of state law at issue be not only unsettled, but also "determinative of the [federal] cause." FLA. STAT. ANN. $\$ 25.031$. Whether the Florida legislature adopted the certification procedure in direct response to Meredith is difficult to determine given that " $[t]$ here are no known recorded reports or hearings with regard to the legislative history of [the statute]." Larry M. Roth, Certified Questions from the Federal Courts: Review and Reproposal, 34 U. MIAMI L. REV. I, 6 n.28 (1979).

152363 U.S. 207, 212 (1960). 
Florida Supreme Court. ${ }^{43}$ The following year, the Florida Supreme Court responded by promulgating rules to govern the certification process, ${ }^{454}$ and the former Fifth Circuit began certifying unsettled questions of state law to that tribunal. Because Clay sought to obtain an authoritative resolution of unsettled questions of state law in order to avoid the potentially unnecessary adjudication of a federal constitutional claim, the case in reality represents a form of Pullman abstention. ${ }^{455}$ Rather than employ traditional modes of abstention, however, the Clay Court sought to encourage use of the more efficient device of certification. For these reasons, Clay is perhaps best characterized as a case of Pullman certification. ${ }^{456}$

The Supreme Court did not embrace certification as a general mechanism to avoid unsettled questions of state law until 1974 in Lehman Brothers $v$. Schein. ${ }^{457}$ There, Chasen, the president of a Florida corporation, disclosed confidential projections showing weak corporate earnings to a representative of Lehman Brothers. Lehman Brothers, in turn, revealed the disappointing projections to a third party who subsequently sold 83,000 shares of the corporation's stock on the New York Stock Exchange, causing the share price to drop sharply. ${ }^{458}$ Shareholders of the corporation filed a derivative action in federal court in New York against all concerned, invoking diversity jurisdiction. Several of the defendants claimed that they had not benefited from the sales, and thus could not be held liable. The plaintiffs countered that the defendants should be held liable under the theory, adopted by the New York Court of Appeals in Diamond $v$. Oreamuno, ${ }^{459}$ that treats inside information as a corporate asset and insiders who misappropriate such information as fiduciaries acting against the interests of the corporation. ${ }^{460}$

The district court applied existing principles of Florida law and dismissed the case for failure to state a claim. ${ }^{461}$ In addition, the district court considered whether the defendants could be held liable

${ }^{453} I d$. at 211.

${ }^{454}$ See In re Florida Appellate Rules, 127 So. 2d 444 (Fla. 1961) (promulgating rule currently codified at FLA. R. APP. P. 9.150).

${ }_{455}$ See supra notes 366-67 and accompanying text (discussing Pullman abstention).

${ }^{436}$ Cf. HART \& WECHSLER, supra note 379, at 1236 (describing Clay as an instance of Pullman abstention).

${ }^{457} 416$ U.S. 386 (1974).

${ }^{458}$ See id. at $387-88$.

159248 N.E.2d 910 (N.Y. 1969).

${ }^{460}$ See Lehman Bros., 416 U.S. at 388.

${ }^{161}$ See id. at 388-89. 
even assuming that Diamond applied, and concluded that they could not because Chasen, the only corporate fiduciary, "never sold any of his holdings on the basis of inside information. ${ }^{.62}$ A divided panel of the court of appeals reversed based on its prediction that Florida courts not only would embrace the New York Court of Appeals' approach in Diamond, but also "would probably' interpret Diamond to make it applicable here. ${ }^{463}$ The dissent unsuccessfully urged the court of appeals to certify these novel questions of state law to the Florida Supreme Court pursuant to Florida's certification procedure. ${ }^{464}$

On review, the Supreme Court vacated the judgment and remanded the case to the court of appeals to "reconsider whether the controlling issue of Florida law should be certified to the Florida Supreme Court. ${ }^{265}$ The Court's action was significant because the case presented no question of federal law, constitutional or otherwise. Rather, the only question before the Court was whether the defendants could be held liable to the plaintiffs under Florida law. Thus, the Court's interest in encouraging certification in cases like Lehman Brothers appears to rest solely on judicial federalism grounds. ${ }^{466} \mathrm{Al}$ though the Court declared that certification "in a given case rests in the sound discretion of the federal court," in this case "resort to it would seem particularly appropriate in view of the novelty of the question and the great unsettlement of Florida law." ${ }^{363}$ Indeed, after recounting the court of appeals' rationale for adopting a broad construction of Diamond, that such a construction "would have 'the prophylactic effect of providing a disincentive to

162 Id. at 389.

${ }^{463}$ Id. (quoting Schein v. Chasen, 478 F.2d 817, 821 (2d Cir. 1973)).

${ }^{164}$ See id. at $389-90$.

${ }^{465}$ Id. at 391-92.

${ }^{466}$ Pullman abstention and certification, by contrast, rest on both judicial federalism and separation-of-powers grounds. Because state law is unsettled, Pullman abstention or certification furthers judicial federalism by permitting state rather than federal courts to make the policy choices necessary to clarify state law. In addition, Pullman abstention and certification permit federal courts to avoid unnecessary adjudication of federal constitutional-law questions, which furthers the constitutional separation of powers by reinforcing "the proper-and properly limited-role of the courts in a democratic society." Warth v. Seldin, 422 U.S. 490, 498 (1975); see, e.g., Spector Motor Serv. v. McLaughlin, Inc., 323 U.S. 101, 105 (1944) ("If there is one doctrine more deeply rooted than any other in the process of constitutional adjudication, it is that we ought not to pass on questions of constitutionality... unless such adjudication is unavoidable.").

167 Lehman Bros., 416 U.S. at 391.

${ }^{463} I d$. 
insider trading," ${ }^{m 69}$ the Court responded: "And so it would. Yet under the regime of [Erie], a State can make just the opposite her law .$"$ Thus, the Court looked to certification both as a means of permitting Florida (rather than a federal court) to make the policy choices reflected in this decision, and as a means of avoiding the more cumbersome (and constitutionally problematic) alternative of abstaining by staying federal proceedings and "remitting the parties to the state court to resolve the controlling state law on which the federal rule may turn."

Following the Supreme Court's decision in Lehman Brothers, both the availability and use of certification increased dramatically. Today, forty-three states, as well as the District of Columbia and Puerto Rico, permit at least some federal courts to certify novel or unsettled questions of state law to the highest state court for authoritative resolution. $^{472}$ Under the procedures adopted in most states, federal courts that wish to certify questions to a state's highest court simply stay their proceedings, certify the question at issue, and wait for the state court to provide an answer. ${ }^{473}$ Such procedures provide federal courts with a valuable means of avoiding the difficult policy choices inherent in

${ }^{169}$ Id. at 389 (citation omitted) (quoting Schein v. Chasen, 478 F.2d 817, 823 (2d Cir. 1973)).

${ }^{470}$ Id. In fact, on remand, the Second Circuit certified the question to the Florida Supreme Court, and that court concluded that "under the facts alleged in the complaint, Florida law does not permit the maintenance of [a] shareholders' derivative suit." Schein v. Chasen, 313 So. 2d 739, 747 (Fla. 1975).

${ }^{171}$ Lehman Bros., 416 U.S. at 390.

${ }^{472}$ See D.C. CODE ANN. $\$ 11-723$ (1987); IOWA CODE ANN. § 684A.1 (West 1987); KAN. STAT. ANN. \$ 60-3201 (1994); MD. CODE ANN., CTS. \& JUD. PROC. § 12-603 (Supp. 1996); MinN. STAT. ANN. § 480.061 (West 1990); NEB. REV. STAT. § 24219 (1995); OKLA. STAT. ANN. tit. 20, $\S \S 1601-12$ (West 1991 \& Supp. 1994); OR. REv. STAT. $\$ 28.200$ (Supp. 1996); WASH. REV. CODE ANN. $\$ 2.60 .020$ (West 1988); W. VA. CODE § 51-1A-1 (1994); WIS. STAT. ANN. § 821.01 (West 1994); ALA. R. APP. P. 18; ALASKA R. APP. P. 407; ARIZ. SUP. CT. R. 27(a); COLO. APP. R. 21.1; CONN. R. APP. P. § 4168; DEL. SUP. CT. R. 41 (a) (ii); FlA. R. APP. P. 9.150; GA. SUP. CT. R. 37; HAW. R. APP. P. 13; IDAHO APP. R. 12.1; ILL. SUP. CT. R. 20; IND. R. APP. P. 15(O); KY. R. CIV. P. 76.37; LA. SUP. CT. R. XII; ME. R. CIV. P. 76B; MASS. SUP. JUD. CT. R. 1:03; MICH. CT. R. 7.305(B); Miss. R. APP. P. 20; MONT. R. APP. P. 44; NEV. R. APP. P. 5; N.H. SUP. CT. R. 34; N.M. R. APP. P. 12-607; N.Y. CT. R. $§ 500.17$; N.D. R. APP. P. 47; OHIO SUP. CT. PRAC. R. XVIII; R.I. SUP. CT. R. art. I, 6; S.C. APP. CT. R. 228; S.D. CT. R. 15-24A-1; TENN. SUP. CT. R. 23; TEX. R. APP. P. 114; UTAH R. APP. P. 41; VA. SUP. CT. R. 5:42; WYO. R. APP. P. 11.01; P.R. SUP. CT. R. 27. At present, seven states do not permit certification: Arkansas, California, Missouri, New Jersey, North Carolina, Pennsylvania, and Vermont.

${ }^{473}$ See UNIF. CERTIFICATION OF QUESTIONS OF LAW ACT $\$ \S 1,8,12$ U.L.A. 86, 96 (1996) (delineating the procedures for certification adopted by 31 states and territories). 
Erie predictions. ${ }^{474}$ Nonetheless, under the Supreme Court's current approach to certification, the decision whether to certify a novel question of state law "in a given case rests in the sound discretion of the federal court. ${ }^{475}$ For this reason, certification patterns vary widely among federal courts and are largely ad hoc. ${ }^{476}$

\section{B. Certification and the Constitutional Structure}

Federal courts quite appropriately restrict their use of certification to cases presenting unsettled questions of state law-that is, questions to which existing sources of state law do not supply determinate answers. ${ }^{47}$ Although the federal courts' use of certification has greatly increased since the Supreme Court extolled the virtues of this procedure in Lehman Brothers v. Schein, ${ }^{478}$ most federal courts exercise their discretion sparingly and treat certification as an extraordinary procedure. Thus, under the current approach, federal courts do not consider mere indeterminacy of state law itself sufficient to justify certification. This section suggests that federal courts should modify this approach by employing a presumption in favor of certification whenever they are called upon to resolve an unsettled question of state law that would entail the exercise of significant policymaking discretion more appropriately left to the states. Such a presumption would implement the principles of judicial federalism underlying Erie and would avoid both the separation-of-powers concerns raised by abstention ${ }^{479}$ and the "political and social" defects associated with prediction and the static approach. ${ }^{480}$

${ }^{174}$ See Lehman Brothers, 416 U.S. at 391 ("When federal judges in New York attempt to predict uncertain Florida law, they act... as 'outsiders' lacking the common exposure to local law which comes from sitting in the jurisdiction.").

${ }^{475} I d$.

${ }^{476}$ See JONA GOLDSCHMIDT, AMERICAN JUdICATURE SOC'Y, CERTIFICATION OF QUESTIONS OF LAW 28 tbl.5 (1995) (detailing certification patterns by circuit between 1990 and 1994, and noting that the Eleventh Circuit granted $91 \%$ of the certification requests it received whereas the Tenth Circuit granted only $31 \%$ of the requests it received).

47 See UNIF. CERTIFICATION OF QUESTIONS OF LAW ACT \$ 8, 12 U.L.A. 96 (1996) (authorizing certification when "it appears to the certifying court that there are no controlling precedents in the decisions of the highest court or intermediate appellate courts of the receiving state").

416 U.S. 386 (1974).

${ }^{479}$ See supra notes 345-58 and accompanying text (discussing separation-of-powers problems caused by Eriebased abstention).

${ }_{180}$ See supra notes $438-41$ and accompanying text (exploring the problems associated with prediction and the static approach). 
Certification is perhaps uniquely suited to further the principles of judicial federalism underlying the Supreme Court's decision in Erie. By allowing state, rather than federal, courts to supply "an authoritative response" ${ }^{\text {"48 }}$ in the very case in which an unsettled question of state law arises, certification ensures that states-acting through agents of their choice-rather than federal courts will exercise the "sovereign prerogative of choice" of unsettled questions of state law. ${ }^{483}$ In this way, certification permits what Erie says the Constitution requires-that "the voice adopted by the State as its own" will "utter the last word" on matters governed by state law. ${ }^{484}$ For this reason, certification is structurally superior to the predictive approach, under which federal courts frequently weigh competing policy considerations in order to resolve unsettled questions of state law. Thus, unlike prediction, certification ensures that federal courts will not "invade[] rights ... reserved by the Constitution to the several States" ${ }^{\text {"85 }}$ by "declar[ing] substantive rules of common law applicable in a State."

Certification also affords several distinct structural advantages over abstention. As Justice Ginsburg recently explained on behalf of a unanimous Court, "[c] ertification procedure, in contrast [to abstention], allows a federal court faced with a novel state law question to put the question directly to the State's highest court, reducing the delay, cutting the cost, and increasing the assurance of gaining an authoritative response." alleviate the separation-of-powers concerns associated with abstention

481 Arizonans for Official English v. Arizona, 117 S. Ct. 1055, 1073 (1997).

${ }^{482}$ Holmes, supra note 49 , at 461.

483 Cf. LeBel, supra note 37, at 1039 ("What certification seems to reveal, therefore, is the centrality of rules and reasons to adjudication that involves the type of decisionmaking-lawmaking rather than law-applying-which is adjudication uniquely within the province of the highest courts of legal systems.").

${ }^{184}$ Erie, 304 U.S. at 79 (quoting Black \& White Taxicab \& Transfer Co. v. Brown \& Yellow Taxicab \& Transfer Co., 276 U.S. 518, 535 (Holmes, J., dissenting)); see also LeBel, supra note 37, at 1016 ("The other-law problem is alleviated by the referral of [an unsettled] question to the highest court of the system whose law governs.").

${ }^{485}$ Erie, 304 U.S. at 80; $c$. Sloviter, supra note 194, at 1684 (stating that "[a]rguably, the incompatibility between diversity jurisdiction and federalism principles could be mitigated by the process of federal certification of state law questions to the state's supreme court").

${ }^{486}$ Erie, 304 U.S. at 78.

${ }^{487}$ Arizonans for Official English v. Arizona, 117 S. Ct. 1055, 1073 (1997). Although the Court in Arizonans for Official English was contrasting Pullman abstention with Pullman certification, the Court's comments have obvious relevance to Eriebased abstention and certification as well. 
by preventing federal courts from "declin[ing] the exercise of jurisdiction which is given" by Congress. ${ }^{488}$ In this regard, it is useful to recall three functions that federal courts perform when they adjudicate cases: law declaration, fact identification, and law application. ${ }^{489}$ Traditional forms of abstention raise separation-of-powers concerns because they require federal courts to relinquish all three functions to state courts, effectively nullifying federal jurisdiction in such cases. ${ }^{490}$ Certification, by contrast, generally requires federal courts to cede only one of these functions-law declaration. Federal courts remain free to undertake necessary fact identification both before and after certification, and to apply relevant principles of state law to the facts once the highest state court has supplied the necessary rules of decision. Because the principles of judicial federalism recognized in Erie preclude federal courts from "declar[ing] substantive rules of common law applicable in a State," ${ }^{491}$ shifting the law-declaration function in diversity cases from federal to state courts should raise few, if any, constitutional concerns. At least since Erie, diversity jurisdiction has been "generally regarded as intended only to insure unbiased protection against the provincialism of state courts in the administration of their own laws in cases involving citizens of other states," ${ }^{492}$ not to provide an alternative source of law. ${ }^{493}$ Certification is fully consistent with this conception of the judicial role in diversity cases.

4ss Cohens v. Virginia, 19 U.S. 264, 403, 6 Wheat. 264, 404 (1821).

189 See Monaghan, supra note 28 , at 234-37. Although "some commentators would insist that the term 'law' cannot be adequately differentiated from related concepts," Professor Monaghan has persuasively argued that "these categories can be neither discarded as vestigal [sic] remains of primitive word magic, nor dissolved by appeals to epistemology, or ... to literary theory. They are practical constructs designed to systematize, order, and control certain forms of social experience." Henry P. Monaghan, Marbury and the Administrative State, 83 COLUM. L. REv. 1, 4 (1983) (footnotes omitted).

${ }^{450}$ See supra notes $345-58$ and accompanying text (discussing the constitutional concerns raised by federal courts' failure to exercise jurisdiction over cases falling within the relevant jurisdictional statutes).

$19 t$ Erie, 304 U.S. at 78.

${ }^{492}$ David P. Currie, Federalism and the Admiralty: "The Devil's Own Mess", 1960 SUP. CT. REV. 158, 163; cf. Casto, supra note 84, at 915-16 (stating that pre-Erie Supreme Court opinions "hinted that one of the purposes of diversity jurisdiction is to afford interstate litigants an unbiased judicial determination of applicable legal principles").

${ }^{493}$ Of course, it is true that Erie's conception of the federal courts' role in diversity cases largely permits state courts to adopt rules of decision ex post and provides little incentive for them to adopt clear rules $e x$ ante. In this regard, it might be argued that the predictive approach has the virtue of encouraging state courts to provide at least some guidance since they know that federal courts will use their words in making their predictions. A presumption favoring certification, by contrast, arguably would un- 
For the foregoing reasons, certification conforms more closeiy to the constitutional structure than either prediction or abstention. In this regard, certification and the static approach are similar. Both approaches alleviate the federalism and separation-of-powers concerns raised by prediction and abstention. Thus, the choice between the static approach and certification turns largely, if not entirely, on extra-constitutional considerations. As previously discussed, the federal courts' use of the static approach may give rise to forum shopping and inequitable administration of the law by encouraging parties benefited by the status quo to steer their cases into federal court, thus depriving state courts of opportunities to adopt novel rules of decision. ${ }^{49}$ Certification, by contrast, largely avoids these "political and social" $"$ "495 defects by affording state courts the opportunity to resolve substantial ambiguity in state law regardless of whether the case is brought in federal or state court. For similar reasons, certification fosters better federal-state relations by minimizing the impact of federal-court jurisdiction on the development of state law. Thus, both the desire to avoid "injustice and confusion," siderations of federal-state comity favor the use of certification over the static approach.

Although Lehman Brothers encouraged federal courts to make greater use of state certification procedures, the Supreme Court's opinion did not go far enough. Given "the novelty of the question"497 presented and the fact that its resolution entailed the exercise of significant policymaking discretion, the Court should have estab-

dermine this incentive because such a presumption would give state courts the first opportunity to resolve questions that involve the exercise of significant policymaking discretion. Although significant from a public-choice standpoint, this observation does not alter either the structural arguments against prediction or those in favor of certification. Once the Supreme Court recognized that it "is not a matter of federal concern" "whether the law of the State shall be declared by its Legislature in a statute or by its highest court in a decision," Erie, 304 U.S. at 78, the Court necessarily provided the state courts with at least some opportunities to impose retroactive obligations upon the parties before them. Whether there are any independent constitutional limits on the states' ability to impose such obligations is beyond the scope of this Article. Cf. BMW of N. Am., Inc. v. Gore, 116 S. Ct. 1589, 1598 (1996) (invalidating punitive damages award as excessive and stating that "[e]lementary notions of fairness enshrined in our constitutional jurisprudence dictate that a person receive fair notice not only of the conduct that will subject him to punishment but also of the severity of the penalty that a State may impose").

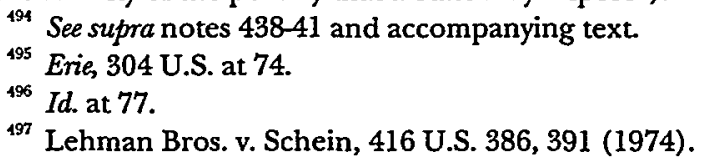


lished a presumption in favor of certification in cases presenting such questions. Lehman Brothers itself illustrates the need for such a presumption. In Lehman Brothers, the Second Circuit erroneously predicted that the Florida Supreme Court would adopt and extend novel principles of New York corporate law to confer a cause of action upon the plaintiff. As previously discussed, the Supreme Court vacated the judgment, declared that certification "would seem particularly appropriate in view of the novelty of the question, ${ }^{n 49}$ and instructed the court of appeals to "reconsider whether the controlling issue of Florida law should be certified to the Florida Supreme Court. ${ }^{, 99}$ On remand, the Second Circuit took the hint and, on this occasion, certified the question to the Florida Supreme Court. The Florida court, in turn, both declined "to adopt the innovative ruling of the New York Court of Appeals in Diamond," and criticized the Second Circuit's "unprecedented expansive reading" of that case. ${ }^{500}$

Although the Second Circuit in Lehman Brothers ultimately elected to certify the question, the decision whether to do so in cases of this kind remains within the federal courts' discretion under the Supreme Court's current approach. Thus, it is entirely possible-and, in fact, occurs quite frequently-that a federal court will exercise its discretion and decide not to employ certification in a case like Lehman Brothers. In such cases, the federal court's prediction that the state's highest court would recognize a novel cause of action raises serious judicial federalism concerns. ${ }^{501}$ In order to avoid constitutional difficulties, a federal court must either certify the question or employ the static approach. Because the static approach poses increased risks of forum shopping and inequitable administration of the law, certification is the only way that federal courts confronted with unsettled questions of state law can both ensure that states retain control over the development of state law $^{502}$ and further the "twin aims" of

193 Id.

199 Id. at 391-92.

${ }^{500}$ Schein v. Chasen, 313 So. 2d 739, 746 (Fla. 1975).

sol See supra notes $195-209$ and accompanying text.

502 States that have authorized federal courts to certify novel questions of state law to the state's highest court presumably seek to retain maximum authority over events subject to the legislative competence of the state. This appears to have been the motivating factor behind Florida's original decision to adopt the first certification statute just two years after the Supreme Court's opinion in Meredith $v$. Winter Haven, 320 U.S. 228 (1943), which urged federal courts to decide even the most difficult questions of state law rather than abstain. See supra notes 448-51 and accompanying text. 
Erie. ${ }^{503}$ These considerations support the establishment of a presumption favoring the use of certification whenever state law is indeterminate and certification is available under state law.

Such a presumption would go far to ensure that federal courts refrain from exercising significant policymaking discretion on behalf of the states. In this regard, a presumption in favor of certification in this context is analogous to the Cheuron deference that federal courts employ in order to avoid making the policy choices inherent in the construction of ambiguous federal statutes administered by federal agencies. $^{504}$ In Cheoron, the Court established a two-step process that federal courts must employ in reviewing the validity of an agency's interpretation of a statute it administers. First, the court must decide "whether Congress has directly spoken to the precise question at issue. If the intent of Congress is clear, that is the end of the matter; for the court, as well as the agency, must give effect to the unambiguously expressed intent of Congress." ${ }^{505}$ Second, "if the statute is silent or ambiguous with respect to the specific issue," then "the court does not simply impose its own construction on the statute." 506 Rather, the court must accept an "interpretation made by the administrator of an agency" so long as it is "reasonable."

For present purposes, the Supreme Court's rationale in Cheuron is at least as significant as the rule it adopted. Statutory ambiguity, according to the Court, "necessarily requires the formulation of policy and the making of rules to fill any gap left, implicitly or explicitly, by Congress." "508 The question presented in Cheuron was which branch of government, agencies or courts, should formulate such policy. Cherron resolves this question in favor of the former by requiring judicial deference to agency interpretations of statutes "'whenever

${ }^{503}$ See Hanna v. Plumer, 380 U.S. 460, 468 (1965) (arguing that a proper test for distinguishing substance from procedure cannot be devised without reference to the "twin aims of the Erie rule").

${ }^{504}$ See Chevron U.S.A. Inc. v. Natural Resources Defense Council, Inc., 467 U.S. 837,843 (1984) (stating that the appropriate question for the courts is whether the "agency's answer is based on a permissible construction of the statute").

${ }_{503} I d$. at $842-43$.

${ }^{506} I d$. at 843 .

${ }^{507} I d$. at 844 .

${ }^{503}$ Id. at 843 (quoting Morton v. Ruiz, 415 U.S. 199, 231 (1974)); see also John F. Manning, Constitutional Structure and Judicial Deference to Agency Interpretations of Agency Rules, 96 Colum. L. REv. 612, 625 (1996) ("Cheuron embraces the assumption that if a silent or ambiguous statute leaves an interpreter room to choose among reasonable alternative understandings, the interpretive choice entails the exercise of substantial policymaking discretion."). 
decision as to the meaning or reach of a statute ... involve[s] reconciling conflicting policies." ${ }^{509}$ This resolution rests on implications from the constitutional structure. As Professor Monaghan has explained, "[a]dministrative application of law is administrative formulation of law whenever it involves elaboration of the statutory norm. ${ }^{\text {} 510}$ Thus, "because it is now generally accepted that the interpretation of an ambiguous text will involve policymaking, Cheoron makes sense of original constitutional commitments to electoral accountability by presuming that Congress has selected agencies rather than courts to resolve serious ambiguities in agencyadministered statutes. ${ }^{\text {,511 }}$ In short, Chevron implements a presumption, derived from the constitutional structure, that "federal judgeswho have no constituency-have a duty to respect legitimate policy choices made by those who do."

The constitutional structure supports an analogous presumption in favor of certifying ambiguous questions of state law to state courts. Like ambiguous federal statutes, ambiguities or "gaps" in state law present opportunities for the exercise of significant policymaking discretion by those who must resolve them. ${ }^{513}$ As Professor Manning has explained, Cheoron's presumption "that Congress allocates interpretive authority to agencies rather than courts" implements "a constitutional commitment to [federal] policymaking by more, rather than less, representative institutions. ${ }^{.514}$ Likewise, a presumption in

so9 467 U.S. at 844 (quoting United States v. Shimer, 367 U.S. 374, 382 (1964)); see also id. at 864 (stating that "policy arguments are more properly addressed to legislators or administrators, not to judges"). In an influential article, Professor Monaghan correctly anticipated Cheuron a year before the Court handed down the decision. See Monaghan, supra note 489, at 6 ("A statement that judicial deference is mandated to an administrative 'interpretation' of a statute is more appropriately understood as a judicial conclusion that some substantive law-making authority has been conferred upon the agency.").

${ }^{510}$ Monaghan, supra note 489, at 29; see also Laurence H. Silberman, Chevron-The Intersection of Law E Policy, 58 GEO. WASH. L. REV. 821, 823 (1990) (stating that "whoever interprets the statute will often have room to choose between two or more plausible interpretations" and that this "sort of choice implicates and sometimes squarely involves policy making").

${ }^{511}$ Manning, supra note 508, at 626; see also Silberman, supra note 510, at 822 (stating that the Cheuron rule "is simply a sound recognition that a political branch, the executive, has a greater claim to make policy choices than the judiciary").

512467 U.S. at 866.

513 See supra notes 39-52 and accompanying text.

${ }^{514}$ Manning, supra note 508, at 634; see also id. at 626 (stating that Chevron "emphasized that our constitutional system favors relatively more accountable agencies, and not relatively less accountable courts, as repositories of policymaking discretion"). 
favor of certifying unsettled questions of state law would effectuate the constitutional preference for state policymaking by agents of the state rather than federal courts. ${ }^{515}$ Thus, the Supreme Court's decision in Cheuron to adopt a presumption necessary to implement the constitutional separation of powers supports the recognition of an analogous presumption in favor of certification in order to further constitutional principles of judicial federalism and the twin aims of Erie. ${ }^{516}$

\section{Implementing a Structural Presumption in Favor of Certification}

This section attempts to identify and briefly address several of the difficulties that federal courts may confront if they attempt to implement a presumption favoring certification of unsettled questions of state law. These difficulties must be evaluated in light of the various aspects of the constitutional structure described in the preceding section. Although analysis at this point is necessarily preliminary and somewhat speculative, none of the potential difficulties appear sufficient to prevent federal courts from adopting a general presumption in favor of certifying unsettled questions of state law to state courts. Some difficulties, however, may suffice to rebut the presumption on occasion. Undoubtedly, if a presumption in favor of certification were adopted, federal and state courts would have to work closely together to implement the presumption and make necessary adjustments.

${ }_{515}$ See supra notes 102-36 and accompanying text.

${ }^{516}$ In this regard, both Cheoron deference and a presumption favoring certification of unsettled questions of state law appear to constitute instances of what Professor Lessig has deemed the "Erie-ffect":

Each of these examples has a common form. In each, there is a discourse that, within law, becomes contested. In each, the contest is about the source of decision for some institutional actor. In each, when that source no longer appears external, or better, when the credibility of it being external becomes contested, this creates, for that institution, an illegitimacy cost. This contest renders illegitimate relative to other institutional actors the practice that before presupposed this exogenous authority. It induces a shift among these institutional actors, so that the practice is placed with the actor who least suffers this illegitimacy cost. In Erie, that actor was the state courts; . . . in Cheoron, that actor is the administering agency. In each, the receiving institution is one with greater political pedigree than the displaced institution. And in each, the shift finds its source in a contestation that renders problematic a practice within law. Thus the Eric-effect.

Lessig, supra note 103, at 1411 (emphasis omitted). 
The first difficulty is that certification is not always available under state law. Currently, forty-three states permit their highest courts to answer certified questions from at least some federal courts. ${ }^{517}$ Although a majority of these states permit federal district courts to certify unsettled questions of state law, a substantial minority allow certification only from federal appellate courts. ${ }^{518}$ This means that certification is not an option in some states and is limited in others. In addition, as discussed below, the highest courts of the states on occasion decline to answer certified questions, even in states that authorize this procedure. ${ }^{519}$ In various circumstances, therefore, certification may be unavailable. ${ }^{520}$ On these occasions, federal courts must employ one of the three less desirable alternatives discussed in this Article: prediction, abstention, or the static approach. ${ }^{521}$ For reasons previously explained, of the three, the static approach appears to be the alternative that conforms most closely to the constitutional structure. ${ }^{522}$ The fact that certification may be "an incomplete solution to the problem of state law decisionmaking by federal courts, ${ }^{, 523}$ however, provides no justification for rejecting its use when the procedure is available, and when its use would further federalstate relations and ensure fairness to the litigants.

The second difficulty with certification is that many federal courts refuse to certify certain questions of state law on the ground that certification "should be confined to issues likely to recur with some frequency. ${ }^{, 524}$ This restriction cannot overcome the structural argu-

${ }^{517}$ See supra note 472 and accompanying text.

${ }^{518}$ See L. Lynn Hogue, Law in a Parallel Universe: Erie's Betrayal, Diversity Jurisdiction, Geongia Conflict of Laws Questions in Contracts Cases in the Eleventh Circuit, and Certification Reform, 11 GA. ST. U. L. REv. 531, 536 (1995) (noting that nine states restrict certification to federal appellate courts only).

${ }^{519}$ See infra note 539 and accompanying text.

${ }^{520}$ See UNIF. CERTIFICATION OF QUESTIONS OF LAW ACT § 8, 12 U.L.A. 96 (1996) (requiring that the indeterminate questions of state law appear to be "determinative of the cause then pending in the certifying court").

${ }^{521}$ Congress might attempt to require state courts to answer unsettled questions of state law certified by federal courts. Such legislation, however, would raise constitutional concerns of its own. Cf. Printz v. United States, 117 S. Ct. 2365, 2383 (1997) (invalidating a federal statutory requirement that state officers conduct background checks on prospective handgun purchasers); New York v. United States, 505 U.S. 144, 149 (1992) (invalidating a federal statutory provision requiring states either to regulate the disposal of nuclear waste generated within their borders or to take title to such waste).

${ }^{522}$ See supra notes $428-37$ and accompanying text.

${ }^{523}$ Sloviter, supra note 194 , at 1686.

${ }^{524}$ DeWeerth v. Baldinger, 836 F.2d 103, 108 n.5 (2d Cir. 1987). 
ments favoring certification of unsettled questions of state law. As an initial matter, the applicability of this condition may be difficult to determine. ${ }^{525}$ Moreover, the apparent rationale for this limitationthat federal courts should not be subjected to the inconvenience and delay associated with certification solely for the benefit of the litigants before the court-is not responsive to the structural arguments in favor of certification. Federal-court prediction of state law-the alternative to certification employed most frequently-threatens judicial federalism regardless of whether or not the question is likely to recur. To be sure, the likelihood that a particular question will infrequently recur may reduce the chances that federal-court adjudication of the question will result in forum shopping and inequitable administration of the law. The infrequency of the question, however, arguably makes it all the more important that state courts be given the opportunity to supply the rule of decision in such cases. The states retain an interest in having their own courts supply the governing law, and this interest includes the opportunity to review and revise such law periodically. Federal-court adjudication of questions that arise infrequently may deny the states this opportunity. In short, the constitutional structure suggests that federal courts should abandon this restriction on the use of certification.

A third potential difficulty with certification arises from the suggestion that federal courts should refuse to certify questions at the request of a party who "has chosen the federal rather than the state forum to resolve state law issues, either by filing initially in federal court or by effecting a timely removal to the federal court. ${ }^{.526}$ As

${ }^{525}$ DeWeerth, discussed supra notes $246-82$ and accompanying text, is illustrative. In DeWeerth, the Second Circuit refused to certify an "unresolved state law issue" to the New York Court of Appeals on the ground that it would not "recur with sufficient frequency to warrant use of the certification procedure." 836 F.2d at 108 n.5. Accordingly, the Second Circuit proceeded to predict how the New York Court of Appeals would decide the issue. A little over three years later, the question reached the New York Court of Appeals in an unrelated case. The court of appeals began by refuting the Second Circuit's justification for refusing to certify the question, stating that: "Actually, the issue has recurred several times in the three years since DeWeerth was decided, including the case now before us." Solomon R. Guggenheim Found. v. Lubell, 569 N.E.2d 426, 429-30 (N.Y. 1991) (citation omitted). The court of appeals then went on to resolve the novel question of state law contrary to the Second Circuit's prediction in DeWeerth. See supra notes 257-64 and accompanying text.

${ }^{526}$ Geri J. Yonover, A Kinder, Gentler Erie: Reining in the Use of Centification, 47 ARK. L. REV. 305, 325 (1994); see, e.g., Stamp v. Insurance Co. of N. Am., 908 F.2d 1375, 1379 (7th Cir. 1990) ("We are not sympathetic to plaintiffs who opt for a federal forum, lose, and then want a second opinion from a state court."); National Bank v. Pearson, 863 F.2d 322, 327 (4th Cir. 1988) ("If [the defendant] had wanted the [state court] to 
Professor Yonover recently put it, "[t]o permit a filing plaintiff or a removing defendant, over the objections of the opposing party, to 'have her cake and eat it too' (having a federal court determination of the facts and a state court determination of the law) seems manifestly unfair. ${ }^{\text {527 }}$ Although certification under these circumstances may seem unfair to the party who wishes to litigate in state court, a federal court's refusal to certify would raise both constitutional and countervailing fairness concerns. Assume, for example, that a plaintiff wishes to sue a defendant on the basis of a novel cause of action that the relevant state's courts have neither recognized, repudiated, nor even addressed. Assume further that the plaintiff can obtain personal jurisdiction over the defendant only in the defendant's home state, and that the plaintiff is concerned about local bias against her in state court. Under these circumstances, it is certainly true that encouraging the plaintiff to file her suit in state court would facilitate authoritative resolution of whatever novel question of state law it presents. On the other hand, assuming that the requirements for diversity jurisdiction have been met, both the Constitution and the jurisdictional statute arguably give the plaintiff a right of access to federal court to avoid local bias. Even if the Constitution prevents federal courts from recognizing novel causes of action on behalf of the states, the plaintiff is still entitled to attempt to have her claim adjudicated in federal court. ${ }^{528}$ Restricting certification as a means of deterring parties from bringing cases in federal court that present unsettled questions of state law arguably burdens the plaintiff's right to invoke federal jurisdiction on the basis of factors not readily apparent on the face of the relevant constitutional and statutory grants. For this reason, such a restriction on certification would give rise to many of the separation-of-powers concerns raised by abstention. ${ }^{529}$ Finally, any unfairness to the party opposing certification would be

rule on the matter, he should not have removed the action to federal court."); see also Study of the Division of Jurisdiction Between State and Federal Courts, 1969 A.L.I. 296 ("It is ordinarily undesirable to allow a defendant a federal determination of facts and a state determination of state law at the cost of delay to a plaintiff who was content to have the whole case promptly determined in the state courts.").

${ }^{527}$ Yonover, supra note 526, at 331 (footnote omitted).

${ }^{528}$ Before the advent of certification, federal courts generally engaged in prediction or abstention in such cases, thus raising either judicial federalism or separationof-powers concerns. See supra Parts II-III. Even if a federal court employs the static approach, however, it is difficult to conclude that the defendant has a right to the static application of state law when certification is otherwise available and would avoid the risk of forum shopping and inequitable administration of the law.

${ }^{529}$ See supra Part III.B. 
equaled or exceeded by the unfairness created by depriving the other party of a federal forum or by subjecting that party to the risk of forum shopping and inequitable administration of the law associated with the static application of state law.

The fourth difficulty is that a presumption in favor of certification may increase the costs and delays associated with federal-court adjudication of state-law claims. ${ }^{530}$ Certification typically requires the parties to brief, and sometimes argue, the question certified to the state's highest court, forcing them to incur the expenses attendant to these activities. It is unclear whether these activities significantly increase overall costs, however, because certification permits the parties to avoid the analogous costs they otherwise would incur if the question were adjudicated in federal court. As for delay, a recent survey found that "[c]ircuit judges waited on average 6.6 months to receive an answer to their most recent certified question" and that "district judges waited an average of 8.2 months for their answer. ${ }^{591}$ Even assuming that this entire period constitutes delay, the Framers appear to have anticipated costs of this kind in establishing a federal system: "In the compound republic of America, the power surrendered by the people is first divided between two distinct governments, and then the portion allotted to each subdivided among distinct and separate departments. Hence a double security arises to the rights of the people." 532 This "double security" undoubtedly imposes numerous costs and burdens on government functions that are not found in systems that operate without checks and balances of this nature. Nonetheless, the Framers thought that the benefits of such features outweighed their costs.

Of course, one might expect the delays associated with certification to increase significantly as federal courts make greater use of this procedure. The available data, however, do not appear to bear this out. $^{593}$ In fact, in a recent survey, about one-half of federal judges polled agreed "that the time delay involved in the certification proc-

${ }^{530}$ See, e.g., Yonover, supra note 526, at 332-33 (discussing the potential delay associated with certification); see also Sloviter, supra note 194, at 1685 (recognizing "that certification generates costs and delays").

${ }^{531}$ GOLDSCHMIDT, supra note 476, at 42; see also CARROLL SERON, FEDERAL JUDICIAL CTR., CERTIFYING QUESTIONS OF STATE LAW 16 tbl.4 (1983) (finding that the highest courts of the states take an average of just six months to answer certified questions); $c f$. Yonover, supra note 526, at 332-333 (discussing various studies which estimate the delays and costs associated with the certification procedure).

${ }_{532}^{53}$ THE FEDERALIST No. 51, supra note 149, at 323.

${ }^{53 s}$ See supra note 531 and accompanying text. 
ess will diminish 'as the procedure becomes used more frequently." States, moreover, undoubtedly have a strong interest in minimizing delay, and have a variety of means at their disposal to do so. These include giving questions certified from federal courts priority on the docket $^{535}$ and creating specialized courts to answer certified questions in a timely manner. ${ }^{556}$ At some point, however, delay may unduly burden the exercise of federal jurisdiction and thus give rise to separation-of-powers concerns similar to those associated with abstention. $^{537}$ When this occurs, federal courts must make the delicate judgment-informed by the constitutional structure-whether the costs occasioned by such delay suffice to rebut the presumption in favor of certification. If so, federal courts should resort to the alternative that most closely conforms to the constitutional structure-the static approach.

A fifth objection to a presumption in favor of certification, related to delay, is that "[i]t would impose an unreasonable and unnecessary burden on [the highest courts of the states] if the certification process were to be invoked routinely whenever a federal court was presented with an unsettled question of [state] law. ${ }^{.538}$ A sufficient answer to this objection appears to be that "the power to answer the certified question is [within] the answering court's discretion under every certification provision, [and therefore] the state supreme court can simply refuse to answer the question if its docket is overburdened. ${ }^{{ }^{599}}$ One commentator has even proposed that states create a special emergency court of appeals whose only duty would be to answer certified questions of state law. ${ }^{540}$ In any event, responsibility

534 GOLDSCHMIDT, supra note 476, at 67 .

${ }^{595}$ See, e.g., KAN. STAT. ANN. $§ 60-3204$ (1994) (stating that certification proceedings in the Kansas Supreme Court "shall have precedence over all other hearings therein, except those of like character"); NEB. REV. STAT. § 24-224 (1995) (requiring that the Nebraska Supreme Court provide "an expedited briefing and hearing process" if it accepts a certification request "so that resolution of the accepted question may be promptly determined and justice not delayed").

${ }^{556}$ Cf. infra note 540 and accompanying text.

537 See supra Part III.B.

${ }^{539}$ L. Cohen \& Co. v. Dun \& Bradstreet, Inc., 629 F. Supp. 1419, 1423 (D. Conn. 1986). At present, however, " $[\mathrm{m}]$ ost state justice[s] $(88 \%)$ disagree with the proposition that answering certified questions from other courts consumes an inordinate amount of their court's time." GOLDSCHMDT, supra note 476 , at 74.

${ }^{339}$ M. Bryan Schneider, "But Answer Came There None": The Michigan Supreme Court and the Certified Question of State Law, 41 WAYNE L. REV. 273, 297 (1995) (footnote omitted).

${ }^{540}$ See Roth, supra note 451 , at $10-14$. 
for creating such a court, as well as for managing the highest court of the state's workload, lies with the states rather than the federal courts. As previously discussed, the states appear to have made certification available to federal courts in large measure to preserve the lawmaking power of the states in cases presenting unsettled questions of state law. Thus, to the extent that states choose to make certification available, federal courts should respect their choice and invoke the procedure whenever doing so would further the constitutional structure and federal-state relations. ${ }^{541}$ To the extent that the burden on state courts impairs the federal courts' ability to exercise their jurisdiction effectively, however, the latter can take this consideration into account in deciding whether the presumption in favor of certification must yield in any given case to the static approach.

A sixth objection is that a presumption in favor of certification may deprive state courts of "the salutary impact of federal court 'predictions' of state law on subsequent state law development." According to proponents of this theory, "cross-pollination" federal and state courts encourages the "migration of ideas" between the two systems, ${ }^{544}$ and has permitted the federal courts to make a "significant contribution to the development of state common law.",545 Perhaps it has, but "contributions" of this kind are at least in tension with the Constitution's recognition that allocation of state lawmaking power rests with the states rather than with the federal courts. As previously discussed, federal court prediction of state law is problematic under the principles of judicial federalism underlying Erie. ${ }^{546}$ By permitting federal courts to make "significant contributions" to the development of state law, the predictive approach necessarily allows

511 It is worth noting that, although certification has increased dramatically during the past few decades, $87 \%$ of states' highest court justices stated in a recent survey that "they were either 'very satisfied' or 'somewhat satisfied' with the certification process as it occurred in their most recent case." GOLDSCHMIDT, supra note 476 , at 43 .

${ }^{542}$ Yonover, supra note 526, at 334 (quoting from the section heading) (capitalization omitted).

${ }^{543}$ Id. at 338.

${ }^{541}$ David L. Shapiro, Federal Diversity Jurisdiction: A Survey and a Proposal, 91 HARV. L. REV. 317,326 (1977).

${ }_{543}$ Yonover, supra note 526, at 339 (citing William M. Landes \& Richard A. Posner, Legal Change, Judicial Behavior, and the Diversity Jurisdiction, 9 J. LEGAL STUD. 367, 372, $386(1980))$.

${ }^{546}$ See supra notes $102-36$ and accompanying text; see also Sloviter, supra note 194 , at 1686-87 (observing that some federal judges "welcome the opportunity to participate, however subtly, in the fashioning of state law" but arguing that "contributing to state law is [not] an appropriate function for federal courts"). 
federal courts to exercise the substantial policymaking discretion required to fashion and apply novel principles of law that have not yet been, and indeed may never be, recognized by state courts. ${ }^{547}$ To be sure, encouraging such judicial creativity on the part of federal courts may provide state courts with "much needed tools of analysis for modernizing [state] common law, ${ }^{, 548}$ and may even lead to greater "uniformity" throughout the United States with respect to novel theories of tort liability. ${ }^{549}$ Similar arguments, however, were made in favor of the Swift doctrine, and Erie nonetheless concluded that benefits of this kind cannot overcome the structural implication that the federal courts' declaration of "substantive rules of common law applicable in a State ${ }^{, 550}$ violates rights "reserved by the Constitution to the several States." ${ }^{551}$ In short, principles of judicial federalism derived from the constitutional structure remain a substantial impediment to the federal courts' exercise of substantial policymaking discretion on behalf of the states. Thus, arguments that a state might in some sense "benefit" from the federal courts' exercise of such discretion on its behalf cannot suffice to defeat a structurally-inspired presumption in favor of certification. ${ }^{552}$

547 See supra notes 39-52 and accompanying text.

${ }^{548}$ Gary Minda, Employment At-Will in the Second Circuit, 52 BROOK. L. REV. 913, 955 (1986).

${ }^{549}$ See Yonover, supra note 526, at 342.

${ }^{550}$ Erie, 304 U.S. at 78.

${ }^{551}$ Id. at 80 . In Erie, the Supreme Court required the lower court on remand to apply Pennsylvania law rather than the more expansive principles of general common law recognized by federal courts at the time. The fact that "[r]ecent state tort trends" may have ultimately "proven the federal position," Yonover, supra note 526, at 340, is irrelevant to the constitutional questions at issue in Erie.

${ }^{552}$ At least one critic of the predictive approach nonetheless remains "skeptical that certification presents a viable solution to either the problem of federal encroachment on state sovereignty or the more limited problem of error in prophecy." Sloviter, supra note 194, at 1684-85. Rather, in Judge Sloviter's view, "the fundamental incompatibility of diversity jurisdiction with the most basic principles of federalism," as well as the fact that "the nationalizing role of diversity jurisdiction is no longer needed," suggest that diversity jurisdiction itself should be amended to redirect "the bulk of diversity cases now filed in federal court" into state courts. Id. at 1687. Although curtailing or abolishing diversity jurisdiction would alleviate the judicial federalism concerns identified in this Article, Congress has steadfastly refused to enact such a jurisdictional shift, and there is little indication that it is now poised to do so. Thus, federal courts must resolve as best they can the various difficulties raised by cases that call upon them to resolve novel or unsettled questions of state law. 


\section{CONCLUSION}

Unsettled questions of state law pose special challenges for federal courts attempting to comply with Erie's command to apply state law to all matters except those governed by the Constitution or acts of Congress. When state law is clear, the federal courts' task is relatively straightforward. When the application of state law is indeterminate, however, federal courts risk encroaching on the constitutional prerogatives of the states if they proceed to exercise the substantial policymaking discretion necessary to fashion substantive rules of common law to govern matters within the legislative competence of the states. If federal courts attempt to predict what rule of decision the highest court of the state would adopt to decide the case before the court, they raise judicial federalism concerns by encroaching on the state's policymaking discretion. Alternatively, if federal courts abstain in order to avoid judicial federalism concerns, they trigger countervailing separation-of-powers concerns by undermining Congress's decision to confer federal jurisdiction in such cases. Employing a static approach avoids the constitutional difficulties raised by prediction and abstention, but may impair the states' ability to control the development of state law and lead to forum shopping and inequitable administration of the law. The federal courts' use of certification resolves these various concerns. Thus, at least until Congress decides to abolish diversity jurisdiction, the constitutional structure suggests that federal courts should employ a presumption in favor of certifying unsettled questions of state law to state courts whenever state law authorizes this procedure. 